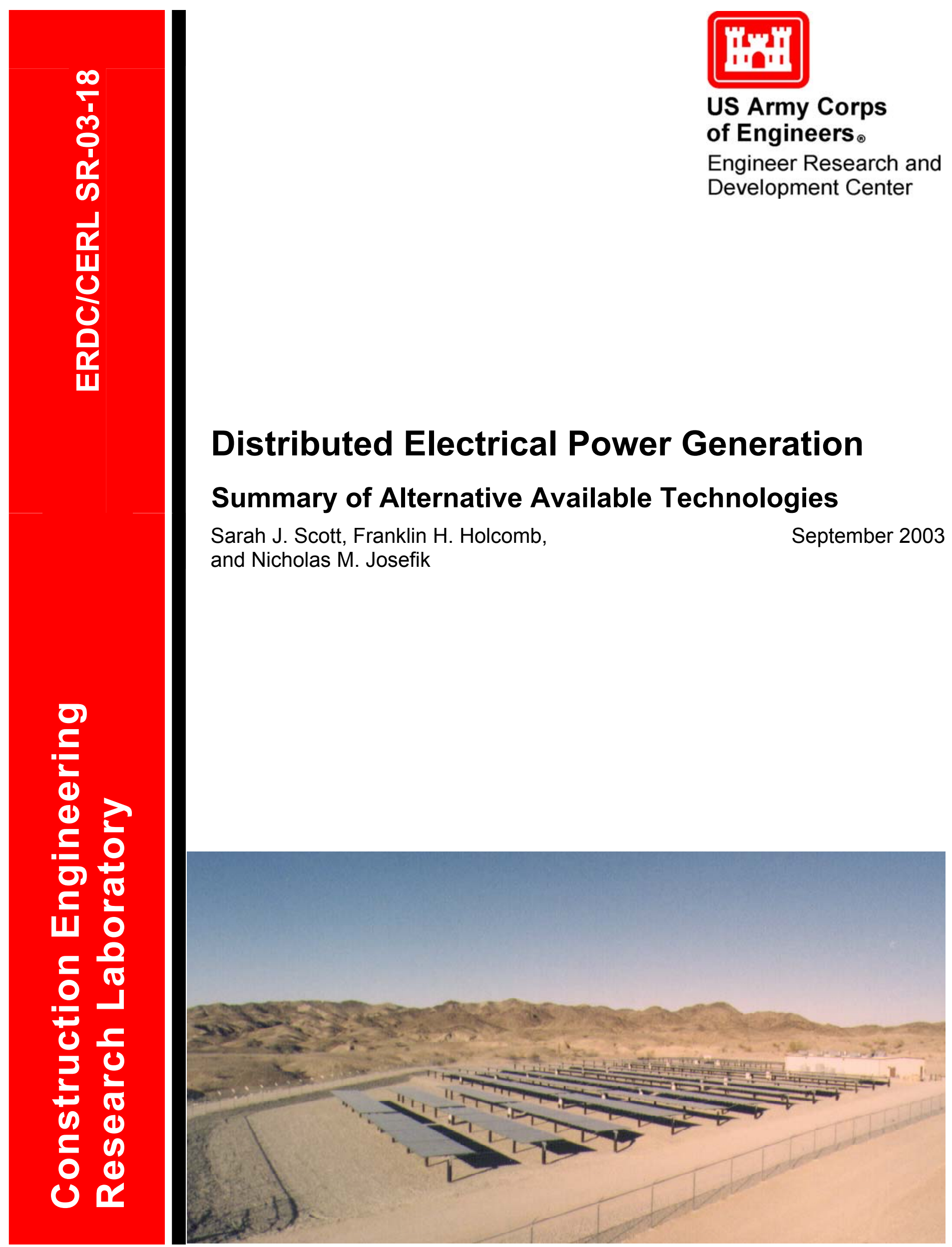





\section{Distributed Electrical Power Generation: Summary of Alternative Available Technologies}

Sarah J. Scott

Jones Technologies, Inc., 4425-F Forbes Boulevard

Lanham, MD 20706-6308

Franklin H. Holcomb and Nicholas M. Josefik

Construction Engineering Research Laboratory

PO Box 9005

Champaign, IL 61826-9005

Final Report

Approved for public release; distribution is unlimited.

Prepared for U.S. Army Corps of Engineers

Washington, DC 20314-1000 
ABSTRACT: The Federal government is the greatest consumer of electricity in the nation. Federal procurement and installation of higher efficiency energy sources promises many benefits, in terms of economy, employment, export, and environment. While distributed generation (DG) technologies offer many of the benefits of alternative, efficient energy sources, few DG systems can currently be commercially purchased "off the shelf," and complicated codes and standards deter potential users. Federal use of distributed generation demonstrates the technology, can help drive down costs, and an help lead the general public to accept a changing energy scheme. This work reviews and describes various distributed generation technologies, including fuel cells, microturbines, wind turbines, photovoltaic arrays, and Stirling engines. Issues such as fuel availability, construction considerations, protection controls are addressed. Sources of further information are provided.

DISCLAIMER: The contents of this report are not to be used for advertising, publication, or promotional purposes.

Citation of trade names does not constitute an official endorsement or approval of the use of such commercial products.

All product names and trademarks cited are the property of their respective owners. The findings of this report are not to be construed as an official Department of the Army position unless so designated by other authorized documents.

DESTROY THIS REPORT WHEN IT IS NO LONGER NEEDED. DO NOT RETURN IT TO THE ORIGINATOR. 


\section{Contents}

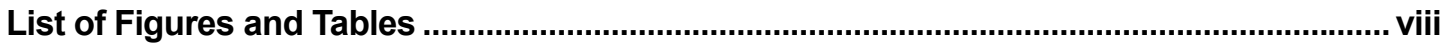

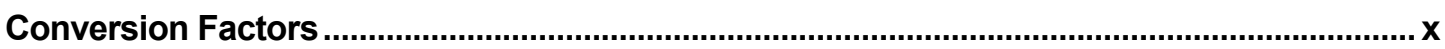

Preface

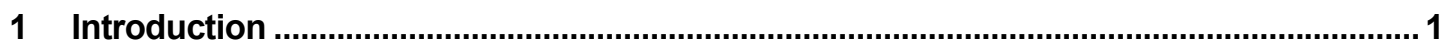

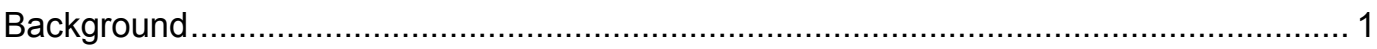

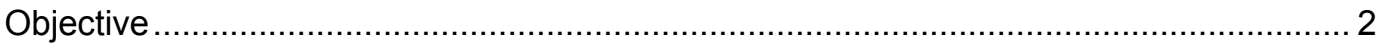

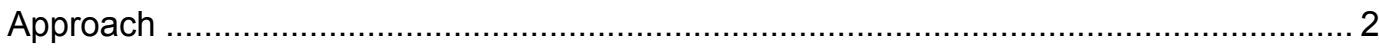

Scope

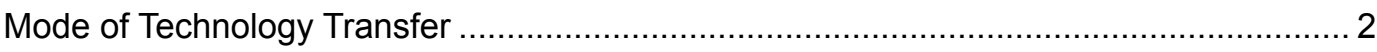

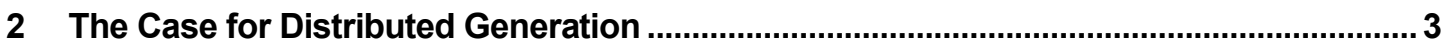

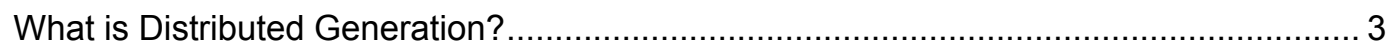

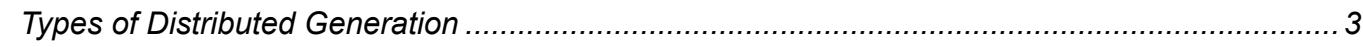

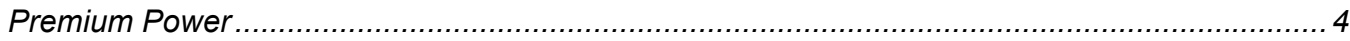

Siting, Technology Characteristics, and Environmental Considerations .......................... 4

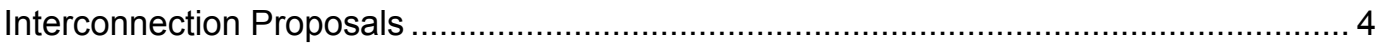

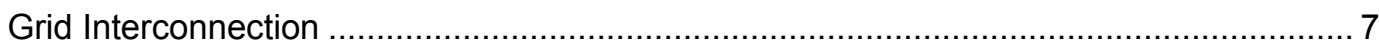

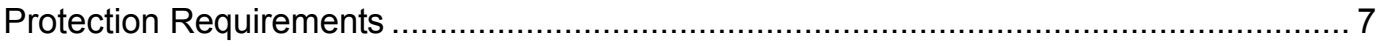

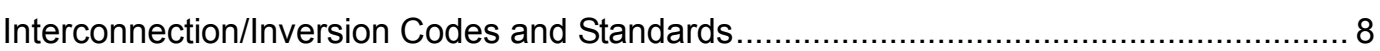

Institute of Electrical and Electronics Engineers (IEEE) …................................................ 8

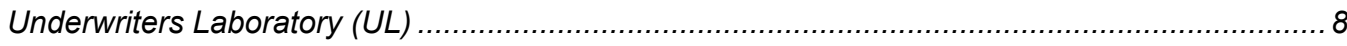

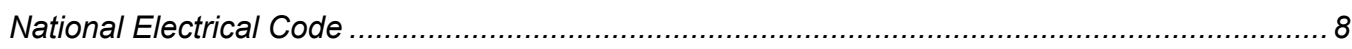

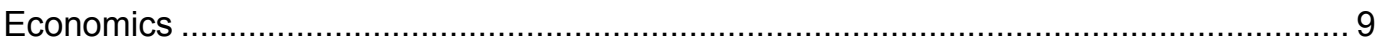

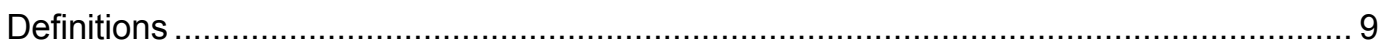

Case Study: Distributed Generation in New York ..................................................... 10

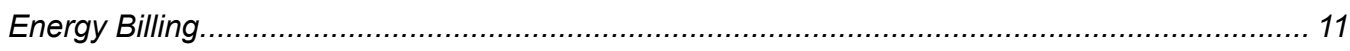

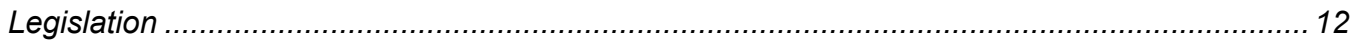

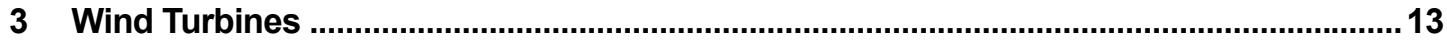

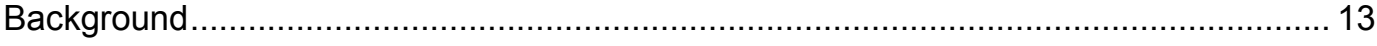

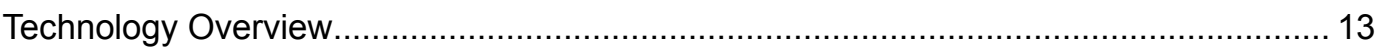

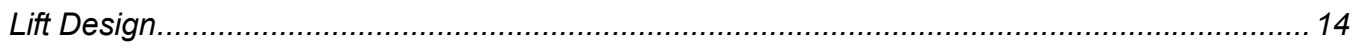

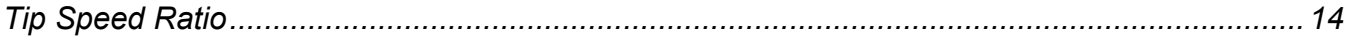




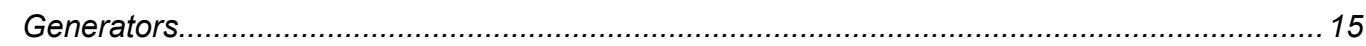

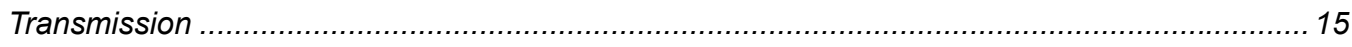

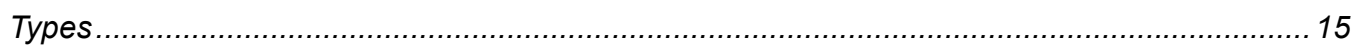

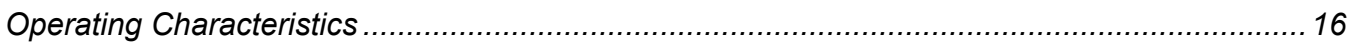

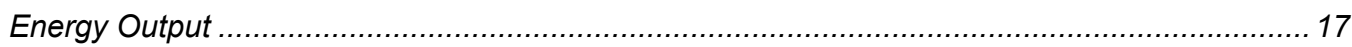

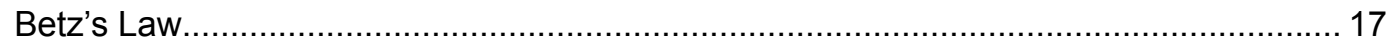

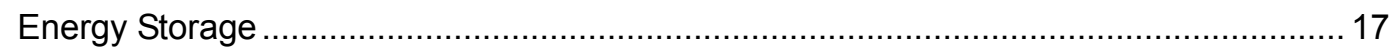

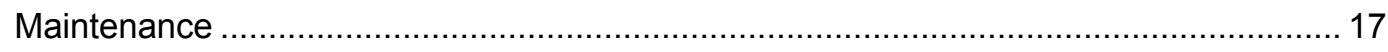

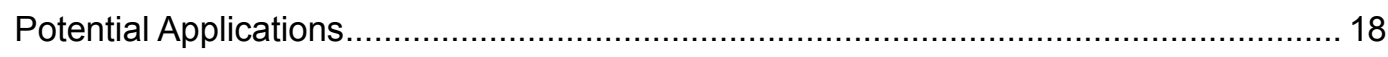

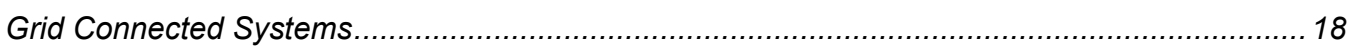

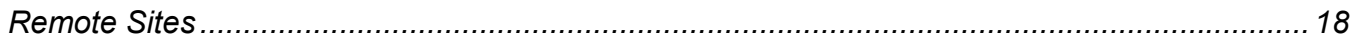

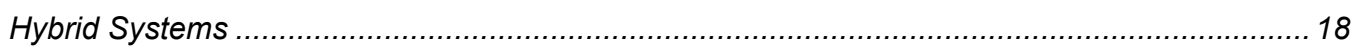

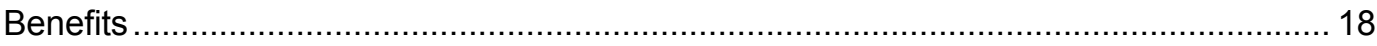

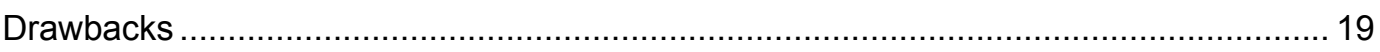

Wind Technology Siting Considerations ……........................................................... 19

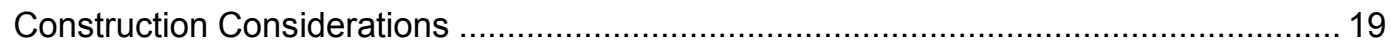

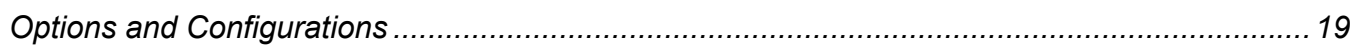

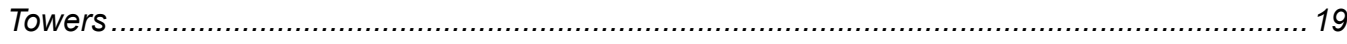

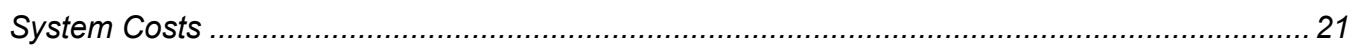

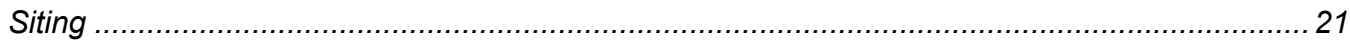

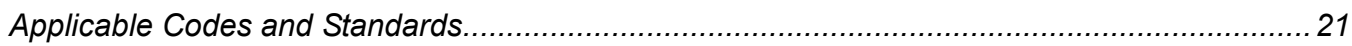

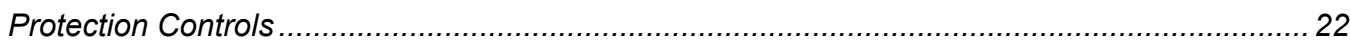

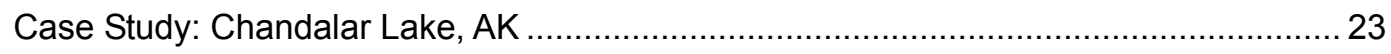

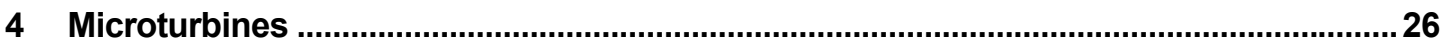

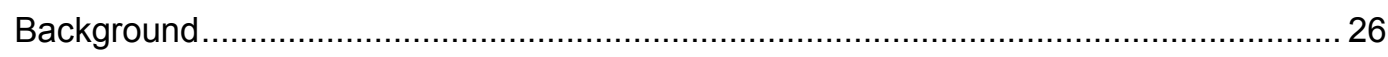

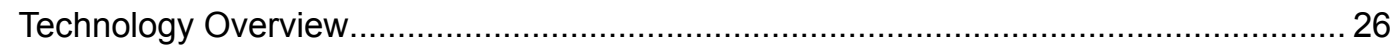

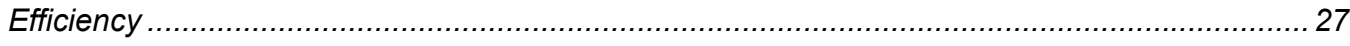

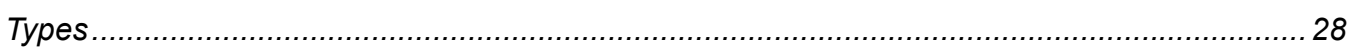

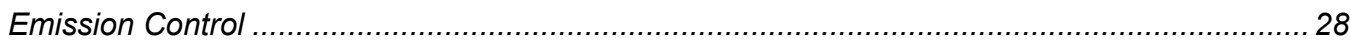

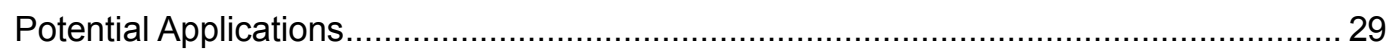

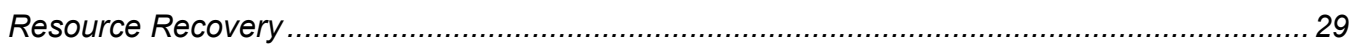

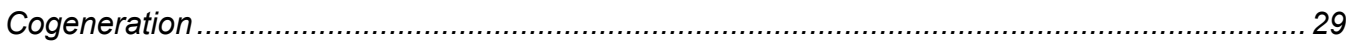

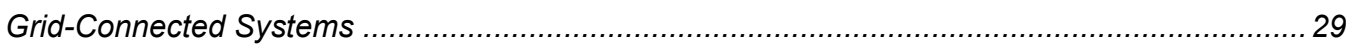

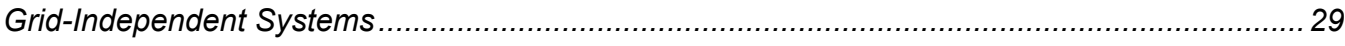

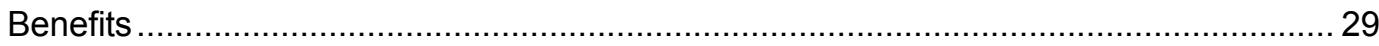

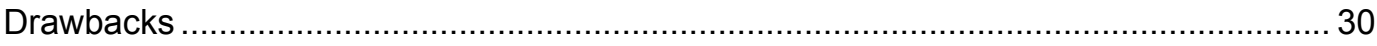

Operation and Maintenance Considerations ............................................................ 30

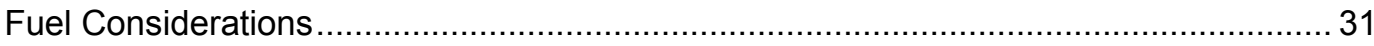

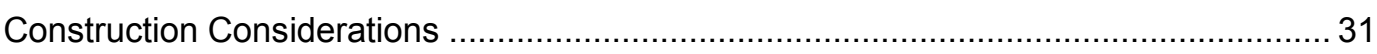

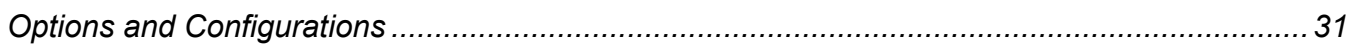

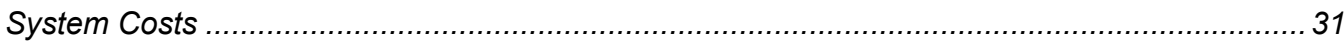




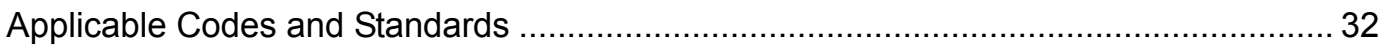

American Society for Testing and Materials (ASTM) International............................................ 32

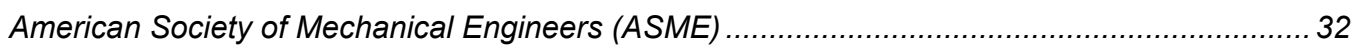

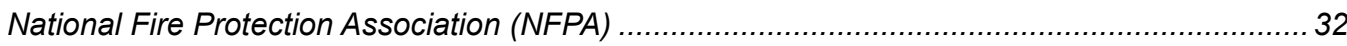

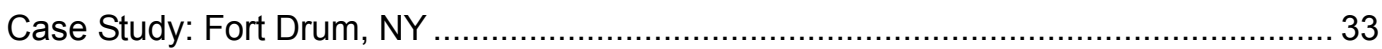

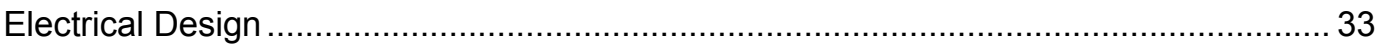

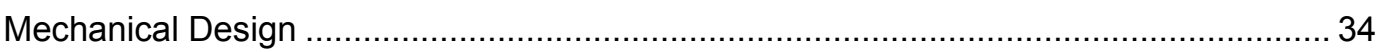

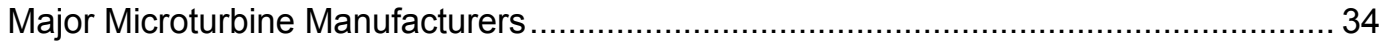

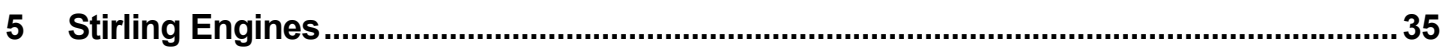

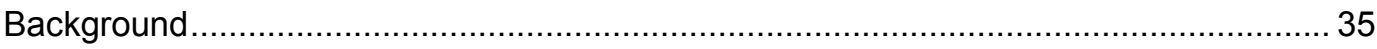

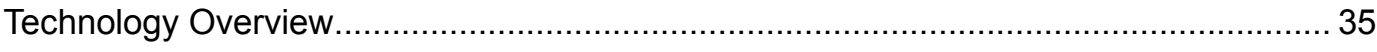

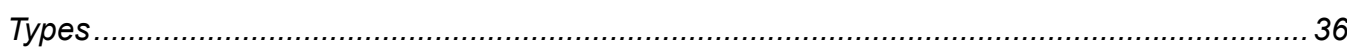

Efficiency

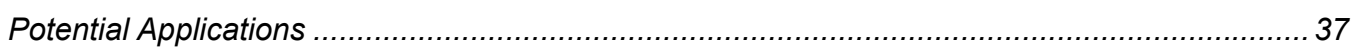

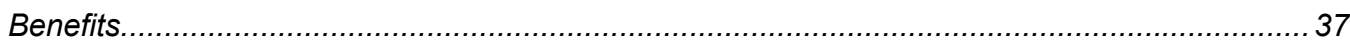

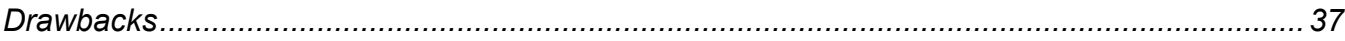

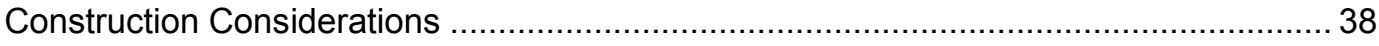

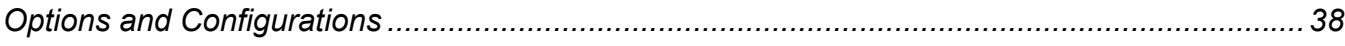

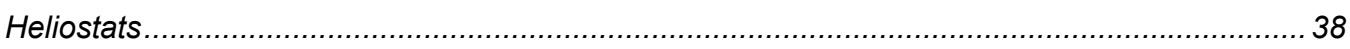

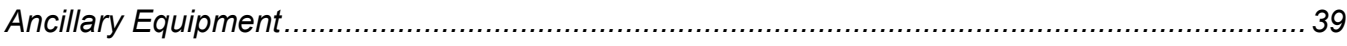

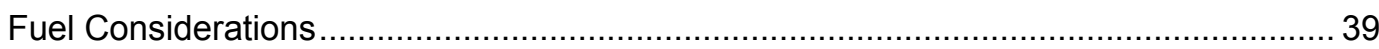

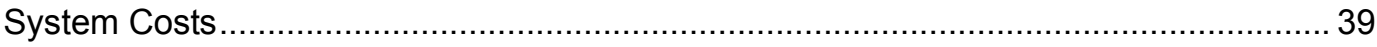

Case Study: Pima-Maricopa Indian Reservation, AZ ................................................... 39

Major Stirling Engine Manufacturers........................................................................... 40

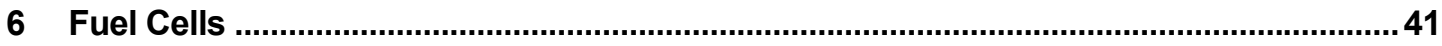

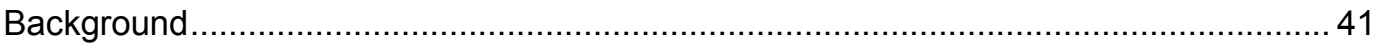

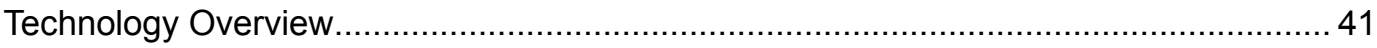

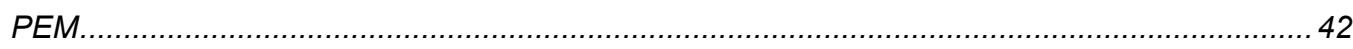

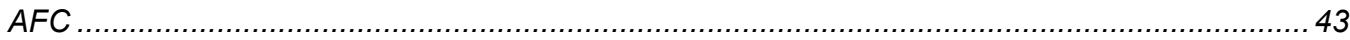

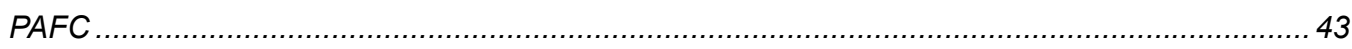

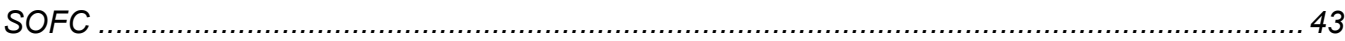

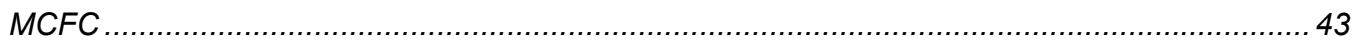

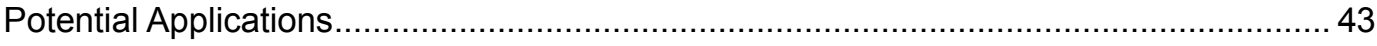

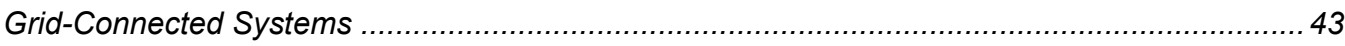

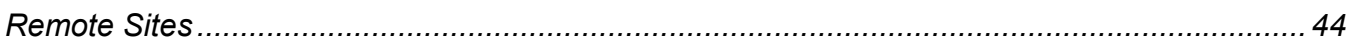

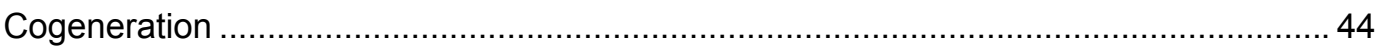

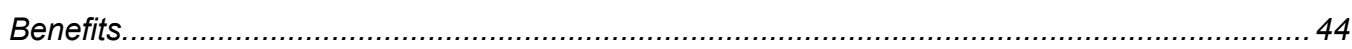

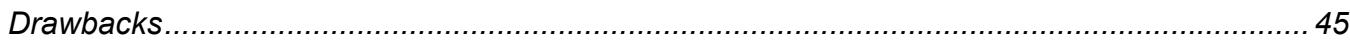

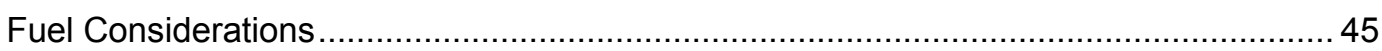

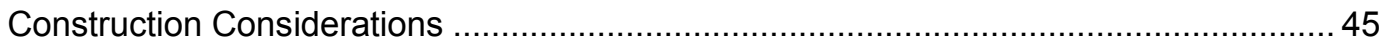




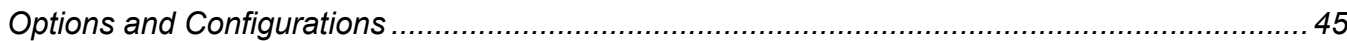

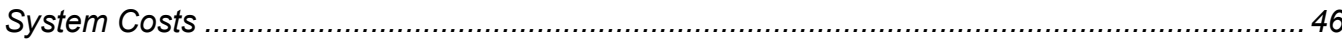

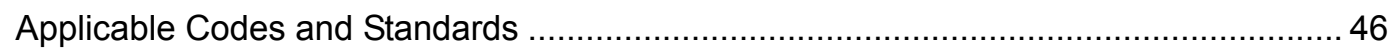

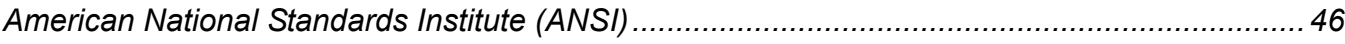

American Gas Association (AGA) ........................................................................ 46

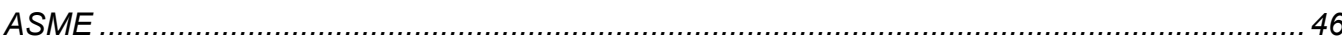

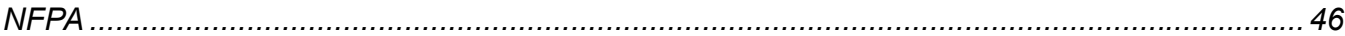

UL 46

Occupational Safety and Health Administration (OSHA) ........................................... 46

Electric Distribution System Considerations .................................................................... 46

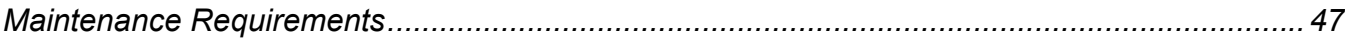

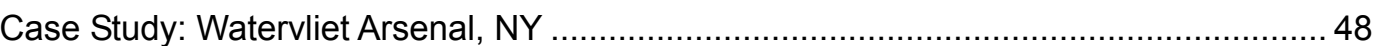

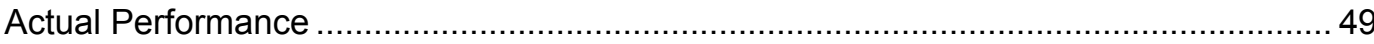

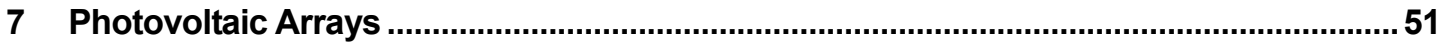

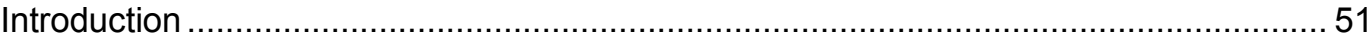

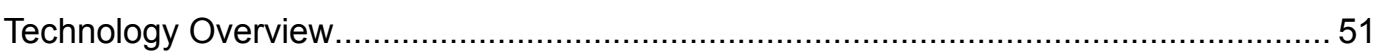

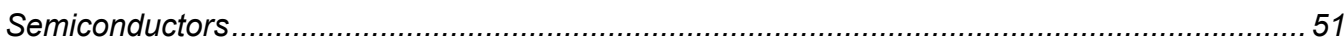

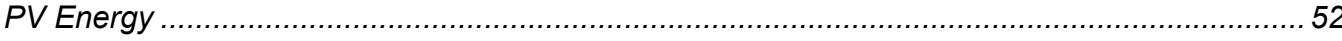

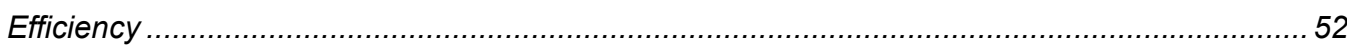

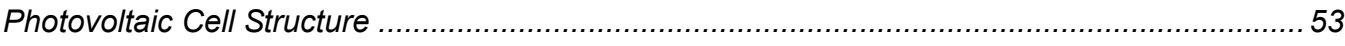

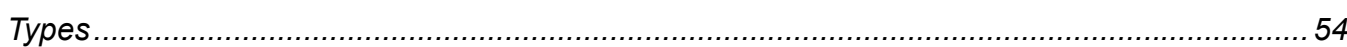

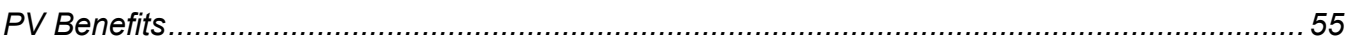

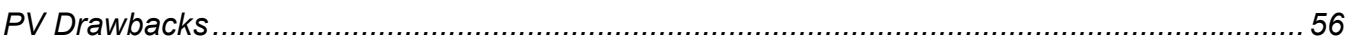

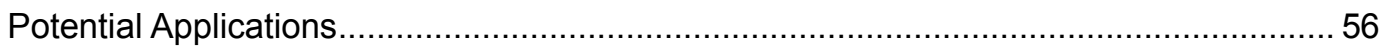

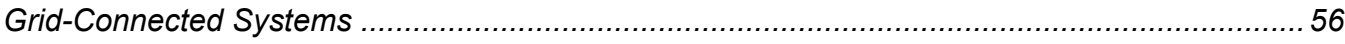

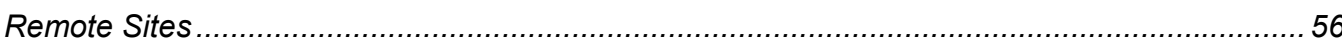

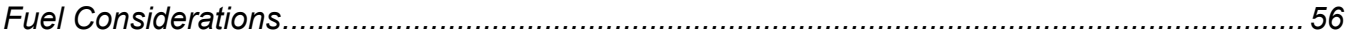

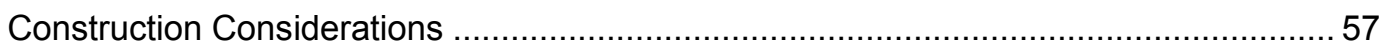

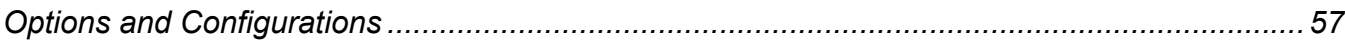

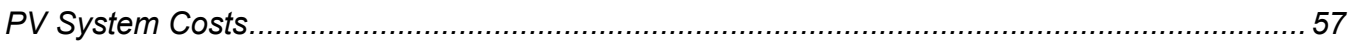

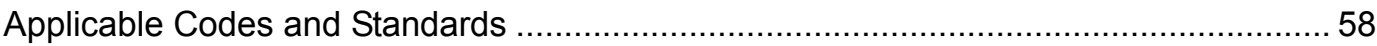

IEEE

UL 59

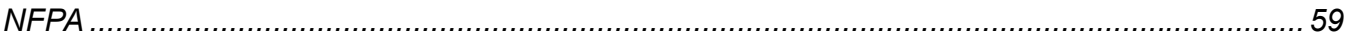

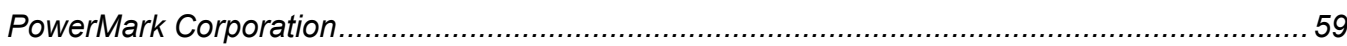

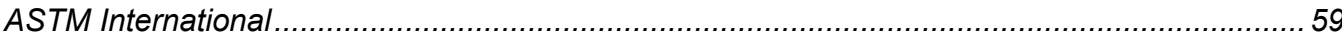

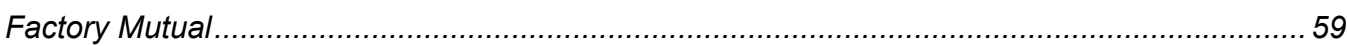

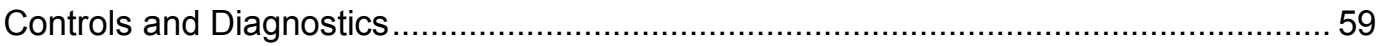

Electric Distribution System Considerations............................................................. 59

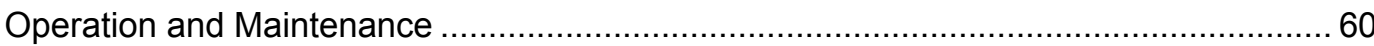

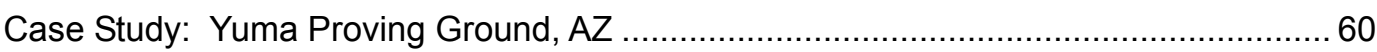




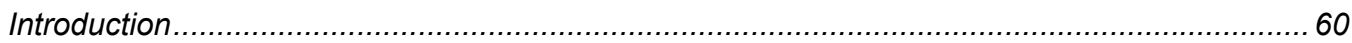

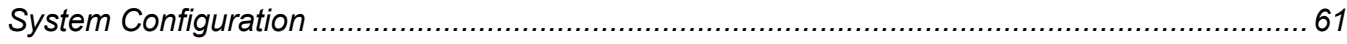

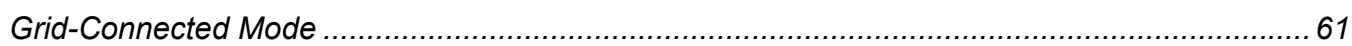

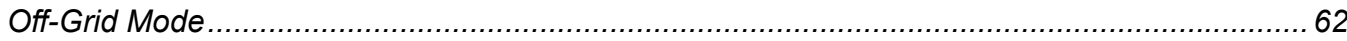

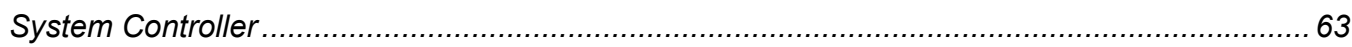

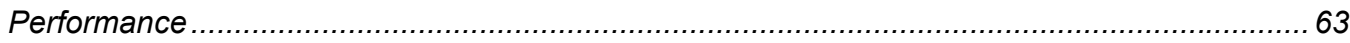

8 Summary

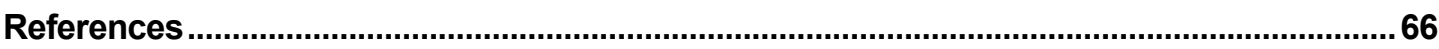

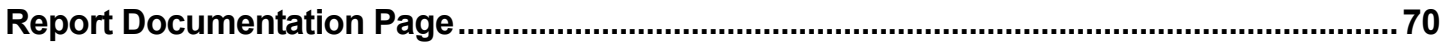




\section{List of Figures and Tables}

Figures

\begin{tabular}{|c|c|}
\hline 1 & Vind turbine components... \\
\hline 2 & Wind distribution in the United States .. \\
\hline 3 & FAA wind turbines at Chandalar Lake.... \\
\hline 4 & Recuperated microturbine block diagram . \\
\hline 5 & IR PowerWorks microturbine... \\
\hline 6 & Capstone microturbines .............. \\
\hline 7 & Fort Drum microturbine and DHW heaters.... \\
\hline 8 & The Stirling cycle .................................... \\
\hline 9 & Solar Dish Stirling system ......................... \\
\hline 10 & Pima-Maricopa Indian Reservation SunDish ........................... \\
\hline 11 & Fuel cell schematic...... \\
\hline 12 & 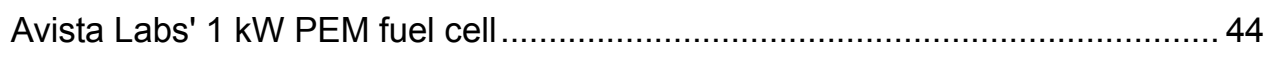 \\
\hline 1 & 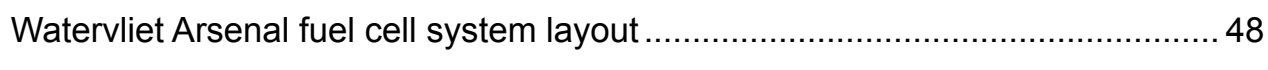 \\
\hline 1 & 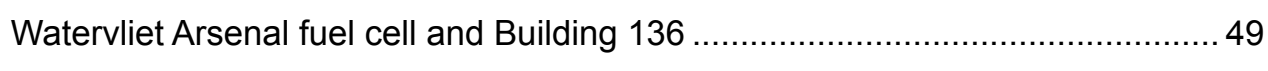 \\
\hline 15 & The effect of the electric field in a PV cell \\
\hline 16 & Operation of a PV cell \\
\hline 17 & 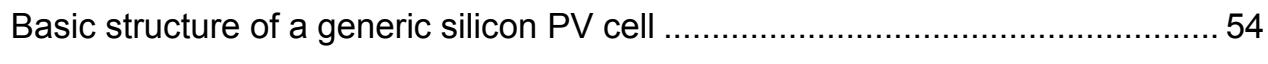 \\
\hline 18 & Availability of solar energy on a surface directly facing the sun..........................5 57 \\
\hline 19 & Typical PV system layout ....... \\
\hline 20 & U.S. Army YPG PV array........................... \\
\hline 21 & 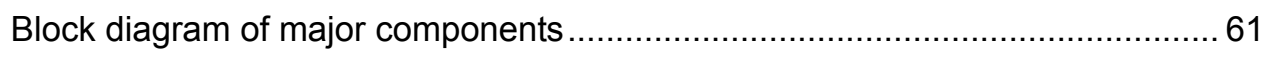 \\
\hline 2 & 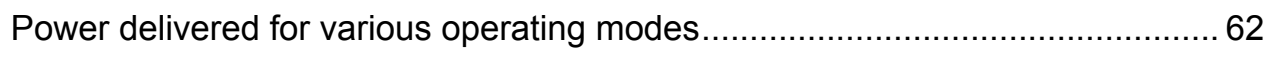 \\
\hline & Operating modes for the YPG PV power station. \\
\hline
\end{tabular}




\section{Tables}

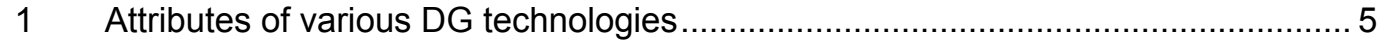

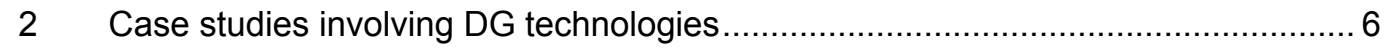

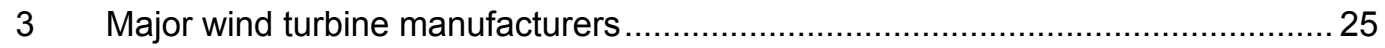

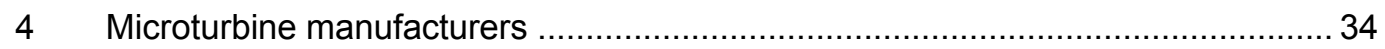

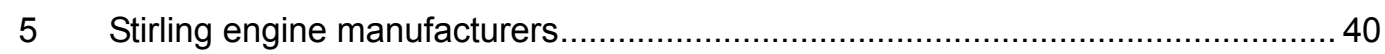

$6 \quad$ Actual performance of the Watervliet Arsenal fuel cell.......................................... 49

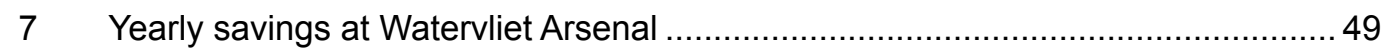

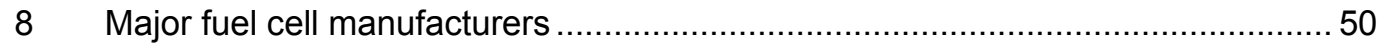

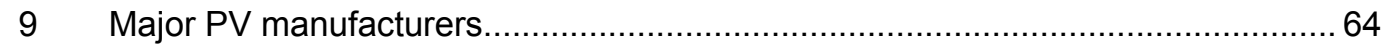




\section{Conversion Factors}

Non-SI* units of measurement used in this report can be converted to SI units as follows:

\begin{tabular}{|l|c|l|}
\hline Multiply & By & To Obtain \\
\hline cubic feet & 0.02831685 & cubic meters \\
\hline degrees (angle) & 0.01745329 & radians \\
\hline degrees Fahrenheit & $(5 / 9) \times\left({ }^{\circ} \mathrm{F}-32\right)$ & degrees Celsius \\
\hline feet & 0.3048 & meters \\
\hline gallons (U.S. liquid) & 0.003785412 & cubic meters \\
\hline horsepower (550 ft-lb force per second) & 745.6999 & watts \\
\hline inches & 0.0254 & meters \\
\hline miles (U.S. statute) & 1.609347 & kilometers \\
\hline pounds (force) per square inch & 0.006894757 & megapascals \\
\hline square feet & 0.09290304 & square meters \\
\hline
\end{tabular}

\footnotetext{
*Système International d'Unités (“International System of Measurement”), commonly known as the "metric system."
} 


\section{Preface}

This study was conducted for the Office of the Director, Defense, Research \& Engineering (ODDR\&E) under Military Interdepartmental Purchase Request No. W81EWF-2094-5873, "Thermoelectric Power Generation for Military Applications," Work Unit T53, "Advanced Distributed Generation.”

The work was performed by the Energy Branch (CF-E), of the Facilities Division (CF), Construction Engineering Research Laboratory (CERL). The CERL Principal Investigator was Franklin H. Holcomb. Sarah J. Scott was a contractor associated with Jones Technologies, Inc., Lanham, MD. Dr. Thomas A. Hartranft was Chief, CF-E, and L. Michael Golish was Chief, CF. The associated Technical Director and project monitor was Gary W. Schanche. The technical editor was Linda L. Wheatley, Information Technology Laboratory - Champaign. The Director of CERL was Dr. Alan W. Moore.

CERL is an element of the U.S. Army Engineer Research and Development Center (ERDC), U.S. Army Corps of Engineers. The Commander and Executive Director of ERDC is COL James R. Rowan, EN. The Director of ERDC is Dr. James R. Houston. 



\section{Introduction}

\section{Background}

The Federal Government is by far the greatest consumer of electricity in the nation. Federal procurement and installation of higher efficiency energy sources would create extraordinary energy cost savings and trigger price reductions needed for significant penetration through manufacturing economies of scale. The Solar Energy Industries Association (SEIA) identifies "Four Es" of alternative energy: economy, employment, export, and environment. Domestically manufactured alternative energy technologies will stimulate economic growth, providing employment opportunities. As the market for these technologies grows, the economy will benefit from technology exports, lessening the country's dependence on fuels obtained overseas. The use of these alternative energies will also lower greenhouse gas emissions and air pollutants, improving environmental quality.

Delivering these alternative energies through distributed generation (DG) ${ }^{*}$ has many distinct benefits. It can provide electricity to remote sites and lowers transmission losses associated with grid distribution. It can provide reliable backup power for critical, grid-connected facilities and can lower stress on the grid by supplying extra power during peak periods. DG provides its users with control over the availability of power. Cogeneration from the DG equipment is possible in the form of cooling and heating; enhancing a 20 to 35 percent generation efficiency to between 75 and 80 percent. DG increases national energy independence, security, and diversity. It reduces the necessity to build new transmission/distribution lines or to upgrade existing ones. DG is well suited to the use of some renewable energy technologies because it can be located close to the user and can be installed in small increments to match the load requirement of the customer. It creates new employment opportunities here in the United States rather than in overseas oil fields.

\footnotetext{
* Chapter 2 describes distributed generation in detail.
} 
DG is not without drawbacks, however. Startup costs can be high. While solar and wind power can be easily accessed, there is no fuel delivery infrastructure in place to provide hydrogen for fuel cells. Few systems at this time can be purchased "off the shelf," and complicated codes and standards deter potential users. Federal use of DG, however, will serve to not only demonstrate the technology and drive down costs, but will lead to public acceptance of a changing energy scheme.

\section{Objective}

The objective of this work was to:

- review and describe various DG technologies, including fuel cells, microturbines, wind turbines, photovoltaic arrays, and Stirling engines

- address issues such as fuel availability, construction considerations, and protection controls

- $\quad$ provide direction to further information about DG technologies.

\section{Approach}

This study was done primarily through literature and web-site review.

\section{Scope}

The subject matter discussed in the report is constantly changing; technologies described here may soon become obsolete. Prior to the design and installation of a DG system, an owner must investigate the latest technological developments and updated codes and standards.

\section{Mode of Technology Transfer}

This report will be made accessible through the World Wide Web (WWW) at: http://www.cecer.army.mil 


\section{The Case for Distributed Generation}

\section{What is Distributed Generation?}

DG is modular electric generation or storage located near the point of use. Distributed systems include microturbines, photovoltaic systems, wind turbines, Stirling engines, and fuel cells. Distributed resources can be grid-connected or operate independently of the grid. In contrast to large, central-station plants, which generate several hundred megawatts (MW), distributed systems typically range in size from less than a kilowatt $(\mathrm{kw})$ to tens of megawatts.

\section{Types of Distributed Generation}

There are four main types of DG applications:

1. Standby generation. Standby generators provide electricity during system outages until service can be restored. This is essential at some facilities, such as hospitals, that require uninterrupted electric service.

2. Peak shaving. This DG technology is operated between 200 and 3000 hours per year during high cost peak periods to reduce overall electricity costs. Units can be operated to reduce the utility's demand charges, to defer buying electricity during high-price periods, or to allow for lower rates from utilities by smoothing site demand.

3. Remote/standalone generation. In isolated or remote applications, installing standalone distributed generation may be more economical than building infrastructure necessary for grid connection.

4. Combined heat and power (cogeneration). In the process of converting fuel into electricity, a large amount of heat is created — on average two-thirds of a fuel's energy content. Customers can use this heat for space heating/cooling or water heating if a power generation system is near their facility. Cogeneration increases efficiency, lowers greenhouse gas emissions, and reduces energy costs. 


\section{Premium Power}

"Premium power" electricity service is provided at a higher level of reliability and/or power quality than typically available from the grid. It includes:

1. Emergency power system. This independent system automatically provides electricity within a specified timeframe to replace the normal source if it fails. It is used to power critical devices, failure of which would result in property damage or threaten health and safety.

2. Standby power system. This independent system provides electricity to replace the normal source if it fails and allows a user's entire facility to continue to operate satisfactorily.

3. True premium power system. This system provides uninterrupted power, free of power surges, dips, voltage transients, and frequency variations. It is not available directly from the grid. It requires power conditioning equipment and standby power.

\section{Siting, Technology Characteristics, and Environmental Considerations}

When choosing which form of DG to install, one must consider the effects the technology will have on its surroundings. For instance, wind turbines have the largest footprint (130 to $550 \mathrm{sq} \mathrm{ft} / \mathrm{kW}$ ) of the considered technologies, followed by photovoltaics (PV) at 1.5 to $9.0 \mathrm{sq} \mathrm{ft} / \mathrm{kW}$, fuel cells at 0.6 to $1.5 \mathrm{sq} \mathrm{ft} / \mathrm{kW}$, Stirling engines at 0.36 to $269 \mathrm{sq} \mathrm{ft} / \mathrm{kW}$, and microturbines at 0.2 to $0.5 \mathrm{sq} \mathrm{ft} / \mathrm{kW}$. Table 1 lists the attributes of each of these DG technologies. Table 2 summarizes the technologies and the case studies presented in Chapters 3-7 of this report.

\section{Interconnection Proposals}

Guidelines are being developed to standardize grid-connected DG systems. While some utilities may require more information and further studies, interconnection proposals should include, as a minimum: an online system diagram, system protection data, location of the DG equipment on the utility system, commissioning date, test data, synchronizing method, and maintenance schedules. 
Table 1. Attributes of various DG technologies.

\begin{tabular}{|c|c|c|c|c|c|}
\hline $\mathrm{D}_{\text {Description }}^{\text {Technology }}$ & Fuel Cells & Stirling Engines & Microturbines & Photovoltaic Arrays & Wind Turbines \\
\hline Manufacturer & ONSI & STM Power Corporation & Capstone & Siemens & Beregey Windpower Co. \\
\hline Size Range (kW) & $<1-2,000$ & $<1-25$ & $25-500$ & $<1-100$ & $<1-5,000$ \\
\hline Size (kW) & 200 & Peak 22.4 & 30 & 450 & 2 Units @ 7.5 \\
\hline Footprint (sq ft/kW) & $0.6-1.5$ & $0.36-269$ & $0.2-0.5$ & $1.5-9$ & $130-550$ \\
\hline Approximate Efficiency (\%) & $30-80$ & $12-20$ & $14-30$ & $5-16$ & $10-30$ \\
\hline Emissions NOx (ppm) & $0.1-1$ & $0-15$ & $9-125$ & NA & NA \\
\hline Emissions $\mathrm{CO}_{2}$ (ppm) & NA & $0-15$ & $9-125$ & NA & NA \\
\hline Installed Cost $(\$ / \mathrm{kW})$ & $4,500-5,500$ & $2,000-50,000$ & $910-1,650$ & $7,100-22,000$ & $2,500-8,500$ \\
\hline Cogeneration & Yes & Yes & Yes & No & No \\
\hline Types & $\begin{array}{l}\text { Alkaline, phosphoric acid, } \\
\text { proton exchange } \\
\text { membrane, solid oxide, } \\
\text { and molten carbonate fuel } \\
\text { cells (AFC, PAFC, PEM, } \\
\text { SOFC, MCFC) }\end{array}$ & Kinematic, Free Piston & $\begin{array}{l}\text { Single Shaft, Double } \\
\text { Shaft }\end{array}$ & $\begin{array}{l}\text { Crystalline Silicon, } \\
\text { Thin Film, Electro- } \\
\text { chemical }\end{array}$ & $\begin{array}{l}\text { Horizontal Axis, Vertical } \\
\text { Axis }\end{array}$ \\
\hline Minimum Requirements & Hydrogen Fuel Source & Heat Source & Combustible Fuel & Solar Energy & Wind Speed 7-10 mph \\
\hline Fuel & $\begin{array}{l}\text { Hydrogen, Natural Gas, } \\
\text { Ethanol, Methanol, Gaso- } \\
\text { line, Diesel, Landfill Gas, } \\
\text { Anaerobic Digester Gas, } \\
\text { any Hydrocarbon Fuel } \\
\end{array}$ & $\begin{array}{l}\text { Propane, Natural Gas, } \\
\text { Gasoline, Diesel, Radio- } \\
\text { isotopes, Solar Energy, } \\
\text { Biomass, any Heat Gen- } \\
\text { erating Process }\end{array}$ & $\begin{array}{l}\text { Natural Gas, LPG, Die- } \\
\text { sel, Kerosene, Jet-A, } \\
\text { Biodiesel, Propane, } \\
\text { Digester Gas, Landfill } \\
\text { Gas }\end{array}$ & Solar Energy & Wind \\
\hline Benefits & $\begin{array}{l}\text { No Moving Parts, Low } \\
\text { Noise, Heat and Water } \\
\text { Byproducts }\end{array}$ & $\begin{array}{l}\text { Zero Emissions, Fuel } \\
\text { Flexibility, Quiet, Small } \\
\text { Footprint, High Reliability, } \\
\text { Long Life, Maintenance } \\
\text { Free, Recover Waste } \\
\text { Heat }\end{array}$ & $\begin{array}{l}\text { Fuel Flexibility, Low } \\
\text { Emissions for Combus- } \\
\text { tion Process, Scalable, } \\
\text { Small Footprint }\end{array}$ & $\begin{array}{l}\text { Zero Emissions, Zero } \\
\text { Fuel Costs, No Moving } \\
\text { Parts, Long Life, Scal- } \\
\text { able, Low Weight }\end{array}$ & $\begin{array}{l}\text { Zero Emissions, No } \\
\text { Thermal Signature, Zero } \\
\text { Fuel Cost, Low Mainte- } \\
\text { nance, Quiet Perform- } \\
\text { ance }\end{array}$ \\
\hline Application & $\begin{array}{l}\text { Grid Connected, Grid In- } \\
\text { dependent, Hybrid with } \\
\text { Stirling Engine }\end{array}$ & $\begin{array}{l}\text { Grid Connected, Grid } \\
\text { Independent, Hybrid with } \\
\text { any Heat Generating } \\
\text { Process. }\end{array}$ & $\begin{array}{l}\text { Grid Connected, Grid } \\
\text { Independent, Hybrid } \\
\text { with Fuel Cell }\end{array}$ & $\begin{array}{l}\text { Grid Connected, Grid } \\
\text { Independent, Hybrid } \\
\text { with Wind Turbine }\end{array}$ & $\begin{array}{l}\text { Grid Connected, Grid } \\
\text { Independent, Hybrid with } \\
\text { PV Array }\end{array}$ \\
\hline
\end{tabular}


Table 2. Case studies involving DG technologies.

\begin{tabular}{|c|c|c|c|c|c|}
\hline Description & Fuel Cells & Stirling Engines & Microturbines & Photovoltaic Arrays & Wind Turbines \\
\hline Location & $\begin{array}{l}\text { Watervliet Arsenal, } \\
\text { Watervliet, NY }\end{array}$ & $\begin{array}{l}\text { Pima-Marcopia Indian } \\
\text { Reservation, AZ }\end{array}$ & Fort Drum, NY & $\begin{array}{l}\text { U.S. Army Yuma Proving } \\
\text { Ground, Yuma, AZ }\end{array}$ & Chandalar Lake, AK \\
\hline Supporters & $\begin{array}{l}\text { U.S. Department of } \\
\text { Defense (DOD) }\end{array}$ & $\begin{array}{l}\text { Science Applications } \\
\text { International Corporation } \\
\text { (SAIC), STM Power Corp., } \\
\text { U.S. Department of Energy } \\
\text { (USDOE) }\end{array}$ & USDOE & $\begin{array}{l}\text { U.S. Army, Navy, Air Force, } \\
\text { Marines, Sandia National } \\
\text { Laboratories, Western Area } \\
\text { Power Administration, U.S. } \\
\text { DOD, USDOE }\end{array}$ & $\begin{array}{l}\text { U.S. Federal Aviation } \\
\text { Administration (FAA) }\end{array}$ \\
\hline Manufacturer & ONSI & STM Power Corporation & Capstone & Siemens & $\begin{array}{l}\text { Beregey Windpower } \\
\text { Company }\end{array}$ \\
\hline Size $(k W)$ & 200 & Peak 22.4 & 30 & 450 & 2 Units @ 7.5 \\
\hline Use/Load & $\begin{array}{l}\text { Boiler Plant Grid } \\
\text { connected Grid } \\
\text { Independent Preheat } \\
\text { Boiler Water }\end{array}$ & $\begin{array}{l}\text { Landfill Demonstration } \\
\text { Grid Connect }\end{array}$ & $\begin{array}{l}\text { Boiler Room Emergency } \\
\text { Backup/30 kW Domestic Hot } \\
\text { Water/ } 880 \text { therms/mo }\end{array}$ & $\begin{array}{l}\text { Water Treatment Plant Grid } \\
\text { Connected Grid } \\
\text { Independent }\end{array}$ & $\begin{array}{l}\text { Aircraft Navigation } \\
\text { Beacon/ } 1520 \text { W AC } \\
\text { Seasonal Heating Load }\end{array}$ \\
\hline
\end{tabular}




\section{Grid Interconnection}

Safety standards for grid interconnection require that local DG-produced power be disconnected rapidly and automatically in the event of a grid failure. This disconnection device prevents powering the utility system from the DG system and protects maintenance personnel. The device should have a visible disconnect for easy and sure confirmation of the switch status. It also must be capable of interrupting full load current and be lockable in the open position.

It may be a disconnect switch, a draw-out breaker, fuse block, or other commonly used means of physical isolation. The independent system operator (ISO) requires all DG to operate within frequency and voltage limits.

Interconnection standards also address coordination with distribution system equipment such as upstream voltage regulators and overcurrent protection devices; transformer connections and grounding; monitoring, data telemetry, and utility remote control; and testing and verification of interconnection relays, islanding prevention, and switchgear and DG control equipment.

Because of the power requirements of common computers and automated equipment, high power quality is a necessity. Increasing interconnected DG sources decreases service interruptions, but also compromises stability. Distortions in the sinusoidal wave power provided by utilities come in the form of power interruption (complete loss of the waveform), voltage sag (decrease in wave amplitude), flicker (momentary voltage swings), and harmonics (higher frequency waves combined with the basic $60 \mathrm{~Hz}$ sinusoid). Concessions must be made to maintain power quality where DG sources are connected to the grid. Many different DG system configurations can be used to avoid distortions when grid power fails, such as using an energy storage device (i.e., a battery) to seamlessly kick in until the DG source has reached set levels and can take over.

\section{Protection Requirements}

Many utilities use circuit breakers that reclose automatically to maintain continuity of service to the greatest possible extent, without damaging equipment or creating an unsafe condition. Automatic reclosing devices interrupt the power in the event of a fault or short circuit, and then re-instate or "reclose" the power after a fixed interval of time. To avoid misoperation in cases where reclosing is used, grid-connected DG systems may be required to switch to isolation within eight to ten cycles. 
Basic protective schemes required at the interconnection interface may include the following: Undervoltage and overvoltage protection, frequency protection, synchronizing relay, phase and ground over-current relays, ground overvoltage, and phase directional overcurrent relays.

\section{Interconnection/Inversion Codes and Standards}

As the grid was designed to accommodate one-way electron flow, most utilities in the United States do not have a standard code of grid interconnection. This can be problematic for DG users. The following sections provide some guidelines, though consultation with local authorities is required.

Institute of Electrical and Electronics Engineers (IEEE)

- P1547 - Draft Standard for Interconnecting Distributed Resources With Electric Power Systems (expected approval late 2003)

\section{Underwriters Laboratory (UL)}

- 1012-6 - Fixed, portable, or stationary systems for use with cathode protection equipment, electric organs, fixed power supply systems, household appliance supply systems, industrial equipment, inverters, office appliance and business equipment power systems, etc.

- 924-8, Automatic battery charging and control equipment, auxiliary lighting equipment, central station battery systems, distribution panels, emergency lighting fixtures, exit lights, inverters, and remote lamp assemblies.

\section{National Electrical Code}

DG customers must be aware of a variety of charges a utility may impose on gridconnected systems, including interconnection charges, metering charges, and standby charges, among others. Federal law (Public Utilities Regulatory Policy Act [PURPA] Section 210) prohibits utilities from assessing discriminatory charges for customers who have their own generation facilities. 
In recent years, net-metering * laws have been enacted in many states, including California, Connecticut, Delaware, Massachusetts, Montana, Nevada, New Hampshire, New Jersey, Ohio, Oregon, Vermont, Virginia, and Washington. Most states with net-metering statutes limit eligibility to small systems.

\section{Economics}

Cost is typically a top priority in designing DG systems. The savings a proposed unit would provide over its lifetime can be calculated by using Equation 1.

$$
S=\frac{-D Q p_{e}}{\left(A / P, r_{d, e}, N\right)}-D C_{c a p}
$$

where:

$$
\begin{array}{lll}
\mathrm{S} & = & \text { life cycle savings } \\
\mathrm{DQp} & = & \text { first year savings, the difference between the amount of energy used mul- } \\
& \text { tiplied by fuel costs for existing and proposed DG energy } \\
\mathrm{DC}_{\text {cap }}= & \text { additional capital cost } \\
\mathrm{N} & = & \text { system life } \\
\mathrm{r}_{\mathrm{d}, \mathrm{e}} & =\left(\mathrm{r}_{\mathrm{d}}-\mathrm{r}_{\mathrm{e}}\right) /\left(1+\mathrm{r}_{\mathrm{dem}}\right) \\
\mathrm{r}_{\mathrm{d}} & =\text { market discount rate } \\
\mathrm{r}_{\mathrm{e}} & =\text { market energy price escalation rate } \\
\mathrm{r}_{\text {dem }} & =\text { market demand charge escalation rate }
\end{array}
$$

so that:

\section{Payback time, $\mathrm{Np}=\mathrm{DC}_{\text {cap }} /($ first year savings $)$.}

Maintenance costs must also be taken into consideration.

\section{Definitions}

- Availability. A measure of system reliability that refers to the number of hours that a power plant is available to produce power, divided by the number of hours in the same period.

\footnotetext{
* Net metering allows a consumer's electric meter to turn backwards when their generators are producing more energy than the consumer is using from the power company. This means that the electricity the consumer generates is valued at the same retail rate as that of the power company. The alternative is to install a separate meter to measure the electricity the generator produces in excess of the consumer's demand, for which the power company pays to the consumer a rate much less than retail.
} 
- Continuous power. Refers to an application in which a DG technology is operated at least 6000 hours per year to allow a facility to generate some or all of its power on a relatively continuous basis.

- Combined Heat and Power (CHP). Also referred to as Cooling, Heating, and Power or cogeneration, this DG technology is operated at least 6000 hours per year to allow a facility to generate some or all of its power. A portion of the DG waste heat is used for water heating, space heating, steam generation, or cooling equipment.

- Green Power. This DG technology is operated to reduce environmental emissions created during electricity generation.

- Heliostat. An instrument consisting of a moving mirror, by which a sunbeam is made apparently stationary by being steadily directed to one spot during the whole of its diurnal period.

- Islanding. A condition in which a portion of the utility system that contains both load and distributed generation is isolated from the remainder of the utility system.

- Net meter. A nondemand, noontime, differentiated meter that measures the reverse flow of electricity to register the difference between the electricity supplied by an electric corporation and the electricity provided to the corporation by a customer-generator.

- PURPA. The PURPA of 1978 requires electric utilities to purchase electricity produced from any qualifying power producers that use renewable energy resources or are cogenerators.

\section{Case Study: Distributed Generation in New York}

New York is one of the few states that has established standardized requirements for interconnection of DG facilities to the utility grid. The New York requirements provide simplified provisions for systems up to $15 \mathrm{~kW}$, including an exemption from the $\$ 350$ application fee, simpler interconnection application and contract forms, a shorter 4-week timeline for processing interconnection requests, an exemption from annual operation and maintenance (O\&M) payments for any utility equipment that has to be installed to protect the utility network from the DG facility, and insurance requirements of no more than $\$ 100,000$.

For facilities over $15 \mathrm{~kW}$ and up to $300 \mathrm{~kW}$, the New York requirements provide for a $\$ 350$ application fee, an 8-week period for processing interconnection requests, annual O\&M payments by the DG facility for utility-installed equipment that the utility concludes is needed to satisfy its requirements, and insurance requirements of up to $\$ 1$ million. 
The State of New York Public Service Commission adopted standard interconnection requirements for DG units in 1999. An 11-step interconnection process is outlined for all DG proposals, including:

1. The potential applicant initiates the communication.

2. Utility reviews the project to determine its nature.

3. Potential applicant files application.

4. Utility initiates coordinated interconnection review and develops cost estimate.

5. Applicant commits to utility's review of proposed design package.

6. Utility reviews applicant's proposed design package.

7. Applicant commits to utility's system modifications.

8. Project is constructed.

9. Applicant's facility is tested in accordance with standard interconnection requirements.

10. Interconnection is completed.

11. Final acceptance is confirmed and utility cost is reconciled.

The Commission details information on specifications for acceptable inverters, power quality, transformers, and testing. A standardized contract is available for interconnection proposals for DG systems less than 300 kilovoltampere (kVA). The following describes examples of DG system requirements in the State of New York, as defined by the Commission:

- The DG owner must provide protection and control equipment to isolate the system from the grid in the case of islanding or faulting. The interrupting device must disconnect the system from the grid within six cycles if the voltage falls below 60 volts root mean square ( $\mathrm{V} \mathrm{rms}$ ) phase to ground and within 2 seconds if the voltage rises above $132 \mathrm{~V} \mathrm{rms}$ phase to ground or falls below $104 \mathrm{~V}$ rms phase to ground. It must disconnect the system within two cycles if the voltage rises above $165 \mathrm{~V}$ rms phase to ground and within six cycles if the frequency falls outside a 59.3 - $60.5 \mathrm{Hertz}(\mathrm{Hz})$ range.

- To avoid out-of-phase reclosing, the owner's protection and control scheme must take into account the utility's practice of reclosing the feeder 12 cycles after being tripped.

- The owner must submit the number of starts per specific time period and maximum starting $\mathrm{kVA}$ draw data for the utility to verify that the voltage dip due to starting is within the visible flicker limits defined by IEEE 519-1992.

\section{Energy Billing}

New York's Public Service Law §66-j details regulations on the billing rates of DG systems. While the law currently specifies photovoltaic power in DG form, it is being amended to include other DG technologies. It not only simplifies the billing process for the utility, but also protects the DG owner, as described in this excerpt: 
An electric corporation shall use net energy metering to measure and charge for the net electricity supplied by the corporation and provided to the corporation by a customer-generator, according to these requirements:

In the event that the amount of electricity supplied by the corporation during the billing period exceeds the amount of electricity produced by a customer-generator, the corporation shall charge the customer-generator for the net electricity supplied at the same rate applicable to service provided to other residential customers.

In the event that the amount of electricity produced by customer-generator during the billing period exceeds the amount of electricity used by the customer-generator, it shall apply a credit to the next bill for service to the customer-generator for the net electricity produced at the same rate applicable to service provided to other residential customers.

At the end of the year or annualized over the period that service is supplied by means of net energy metering, the corporation shall promptly issue payment at its avoided cost to the customer-generator for the value of any remaining credit for the excess electricity produced during the year or over the annualized period by the customer-generator.

\section{Legislation}

The New York State senate is developing legislation encouraging the use of alternative energies in DG. Relevant bills include:

- A5322 - Exempts clean energy technologies from sales and use taxes

- A6447 - Makes provisions for net metering for wind electric generation

- A11789 - Requires a determination on the siting of a wind energy production facility in the county of Lewis within 6 months of an application

- $\quad S 4609$ - Requires electric corporations to interconnect to residential and commercial wind-generating systems and provide net energy metering; provides income tax credit

- $A 8748$ - Provides for installation of distributed generation that would enhance customer choice for electricity and accelerate the benefits of electric utility deregulation

- A8976a, A0431 - Increases funding for renewable energy from state power authorities by $\$ 300$ million annually, and prohibits utilities from charging "exit fees," "standby charges," or unreasonable interconnection costs to customers who use wind and solar energy to meet electric power needs. Allows net metering for wind turbines. 


\section{Wind Turbines}

\section{Background}

Humans were harnessing the energy of the wind to propel boats along the Nile River as early as 5000 B.C.E. By 200 B.C.E., simple windmills in China were pumping water, while vertical-axis windmills with woven reed sails were grinding grain in the Middle East. By the 11th century, windmills were being used extensively for food production. The Dutch adapted the windmill for draining lakes and marshes, and this technology was brought to "the new world" to pump water for farms and eventually generate electricity.

Industrialization brought about the downfall of windmill use. First the steam engine gained popularity, and by the 1930s, the Rural Electrification Administration's programs had brought inexpensive electric power to most rural areas in the United States via the power grid. Industrialization also sparked the development of larger windmills to generate electricity, though. Wind turbines appeared in Denmark as early as 1890. In the 1940s the largest wind turbine of the time began operating on a Vermont hilltop known as Grandpa's Knob. This turbine, rated at 1.25 MW in winds of about 30 miles per hour ( $\mathrm{mph}$ ), fed electric power to the local utility network for several months during World War II.

The popularity of using wind energy has always fluctuated with the price of fossil fuels. When fuel prices fell after World War II, interest in wind turbines waned, but when the price of oil skyrocketed in the 1970s, so did worldwide interest in wind turbine generators. New wind turbine technologies were demonstrated at wind farms in the United States and Europe. Today interest in wind power in DG is constantly expanding. Technology improvements, combined with the zero cost of fuel, are making wind power cost-competitive with traditional energy sources.

\section{Technology Overview}

Wind turbine gears connect the low-speed shaft to the high-speed shaft and increase the rotational speeds from about 30 to 60 rotations per minute (rpm) to about 1200 to $1500 \mathrm{rpm}$, the rotational speed required by most generators to produce electricity. 
Typically an off-the-shelf induction generator that produces 60-cycle alternating current (AC) electricity is used in the turbine. A high-speed shaft (Figure 1) turns the generator, while a rotor turns the low-speed shaft at about 30 to $60 \mathrm{rpm}$. The rotor attaches to the nacelle, which sits atop the tower and includes the gearbox, low- and high-speed shafts, generator, controller, and brake. A cover protects the components inside the nacelle. The blades and the hub together are called the rotor. Upwind turbines face into the wind; the yaw drive is used to keep the rotor facing into the wind as the wind direction changes. Downwind turbines do not require a yaw drive; the wind blows the rotor downwind.

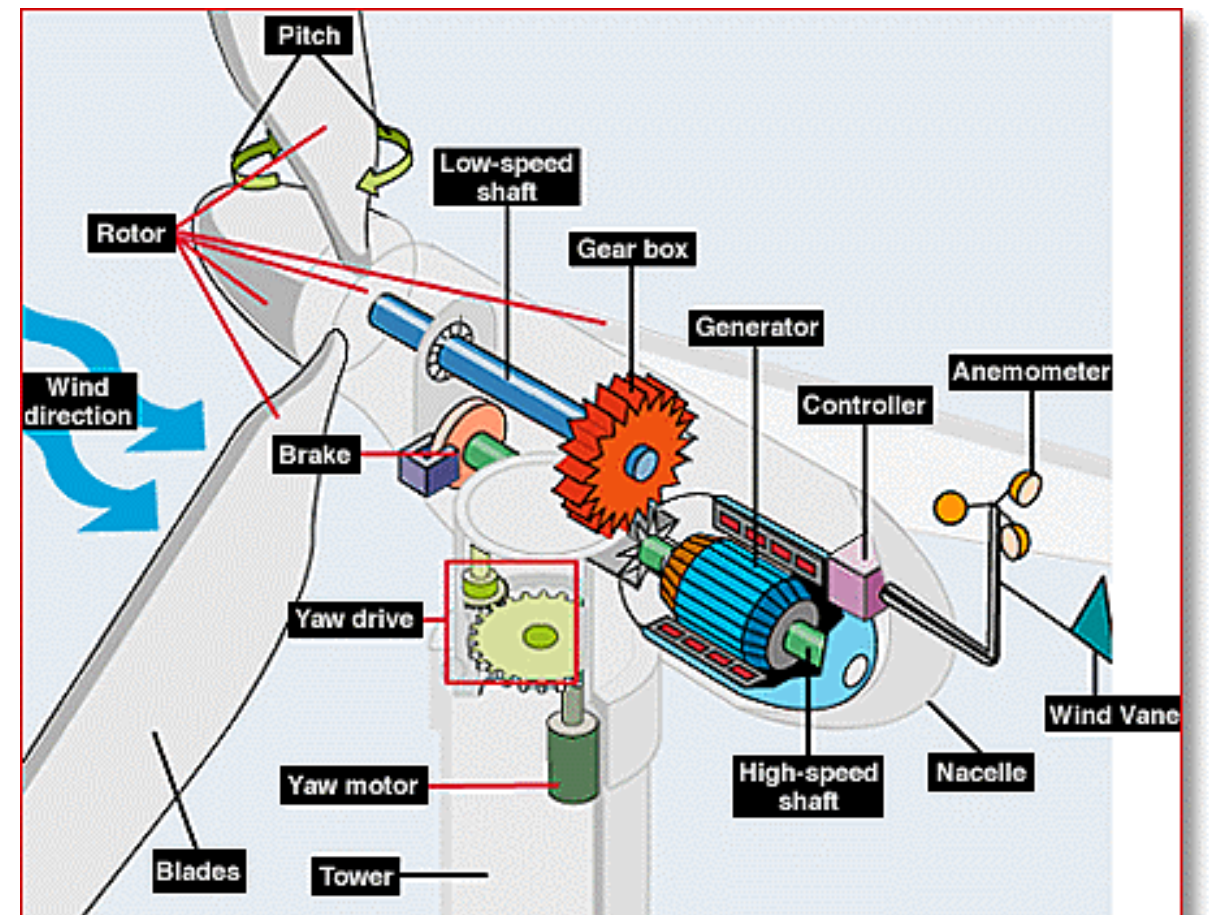

Figure 1. Wind turbine components (courtesy of DOE Wind Energy Program).

\section{Lift Design}

Wind turbine blades are essentially airfoils. When air flows past the blade, a wind speed and pressure differential is created between the upper and lower blade surfaces. The pressure at the lower surface is greater and thus acts to "lift" the blade. When blades are attached to a central axis, like a wind turbine rotor, the lift is translated into rotational motion.

\section{Tip Speed Ratio}

The tip-speed is the ratio of the rotational speed of the blade to the wind speed. The larger this ratio, the faster the rotation of the wind turbine rotor at a given wind speed. Electricity generation requires high rotational speeds. Lift-type wind tur- 
bines have maximum tip-speed ratios of around 10, while drag-type ratios are approximately 1. Given the high rotational speed requirements of electrical generators, the lift-type wind turbine is clearly most practical for this application.

The number of blades that make up a rotor and the total area they cover affect wind turbine performance. For a lift-type rotor to function effectively, the wind must flow smoothly over the blades. Blades should be spaced apart far enough to avoid turbulence, which is why most wind turbines have only two or three blades on their rotors.

\section{Generators}

The generator converts the turning motion of a wind turbine's blades into electricity. Inside this component, coils of wire are rotated in a magnetic field to produce electricity. Different generator designs produce either AC or direct current (DC). The generator's rating, or size, depends on the length of the wind turbine's blades because more energy is captured by longer blades. DC generators are normally used in battery charging applications and for operating DC appliances and machinery. They also can be used with an inverter to convert DC current to AC electricity.

\section{Transmission}

A wind turbine rotor's revolutions per minute can range between 40 and $400 \mathrm{rpm}$, depending on the model and the wind speed. Generators typically require 1200 to $1800 \mathrm{rpm}$, so a gear box is typically required to increase the rotation of the generator to the speeds necessary for efficient electricity production. Some DC-type wind turbines do not use transmissions. These direct drive systems have a direct link between the rotor and generator. Without a transmission, wind turbine complexity and maintenance requirements are reduced, but a much larger generator is required to deliver the same power output as the AC-type wind turbines.

\section{Types}

Wind turbines are classified into two general types: horizontal axis and vertical axis.

\section{Horizontal axis}

This wind turbine design is the most common. The axis of blade rotation is parallel to the wind flow. Some machines are designed to operate in an upwind mode, with the blades upwind of the tower. In this case, a tail vane is usually used to keep the blades facing into the wind. Other designs operate in a downwind mode so that the 
wind passes the tower before striking the blades. Without a tail vane, the machine rotor naturally tracks the wind in a downwind mode. Some very large wind turbines use a motor-driven mechanism that turns the machine in response to a wind direction sensor mounted on the tower.

\section{Vertical axis}

Vertical axis wind turbines are far less common than horizontal turbines. The only such turbine manufactured commercially at any volume is the Darrieus machine, characterized by its two or three $\mathrm{C}$-shaped rotor blades. The advantages of a vertical axis turbine are: the generator and gearbox can be placed on the ground, eliminating the need for a tower, and no yaw mechanism is required to turn the rotor against the wind. Its disadvantages are: wind speeds are lower closer to the ground (which lowers efficiency), and the machine is not self starting (which posed a problem for off-grid systems). Also, replacing the main bearing for the rotor requires the removal of the rotor, which is essentially the disassembly of the entire vertical axis turbine.

\section{Operating Characteristics}

All wind machines share certain operating characteristics, such as cut-in, rated, and cut-out wind speeds.

\section{Cut-in speed}

Cut-in speed is the minimum wind speed at which the blades will turn and generate usable power, typically between 7 and $10 \mathrm{mph}$.

\section{Rated speed}

The rated speed is the minimum wind speed at which the wind turbine will generate its designated rated power. Rated speed for most machines is in the range of 25 to $35 \mathrm{mph}$. At wind speeds between cut-in and rated, the power output from a wind turbine increases as the wind increases. The output of most machines levels off above the rated speed, as detailed by their power curves.

\section{Cut-out speed}

Cut-out speed is the maximum wind speed at which the turbine can safely operate, typically around 50-60 mph. At this point, the turbine will shut down to protect the rotor and drive train machinery from damage. Not all wind turbines have this feature. 


\section{Energy Output}

Taller towers and larger rotors increase the amount of power produced by a wind turbine. This can be calculated by:

$$
\text { Power }=C_{p} 1 / 2 \rho A V^{3}
$$

where:

$\mathrm{C}_{\mathrm{p}}=$ power coefficient, ranging from $0.2-0.4$ (theoretical $\max =0.59$ )

$\rho=$ air density, lb/cu ft

$\mathrm{A}=$ rotor swept area $=\Pi \mathrm{D}^{2 / 4}$, where $\mathrm{D}=$ rotor diameter in feet

$\mathrm{V}=$ wind speed, $\mathrm{mph}$.

\section{Betz's Law}

The wind turbine extracts energy by slowing the wind down. If an attempt was made to extract all the energy, the air would move away at zero speed and could not leave the turbine. Hence, no energy would be extracted as no air would enter the turbine's rotor. An ideal wind turbine would slow the wind by two-thirds of its original speed. In 1919 Albert Betz proved a wind turbine can convert a maximum of 59 percent of the kinetic energy in the wind to mechanical energy. A more typical efficiency is 35 to 45 percent. A complete wind energy system, including rotor, transmission, generator, storage and other devices, which all have less than perfect efficiencies, will deliver between 10 and 30 percent of the original energy available in the wind. More information on basic wind turbine design is available through:

http://www.energy.iastate.edu/WindManual/Text-Systems.html

\section{Energy Storage}

The least costly batteries for wind applications are deep cycle, heavy-duty, industrial-type lead-acid batteries. They can be fully charged and discharged. Gel-cell lead-acid batteries have improved the safety of the traditional liquid-acid battery by containing the hydrogen that can be produced during charging and by preventing the liquid acid from spilling.

\section{Maintenance}

Wind turbines are subject to extreme physical forces. The tips of a wind turbine rotor can reach speeds of up to $300 \mathrm{mph}$. Hail, dirt, and insects contacting the blades 
at these speeds can cause wear to the blade edges. Bearings that support the rotor or other moving parts are also subject to wear. The entire wind system, including the tower, storage devices, and wiring should be inspected at least once a year. Routine maintenance might include changing the transmission oil, greasing the bearings, and visually inspecting the condition of the blades, tower, and electrical connections. Manufacturers claim the expected lifetime of wind turbines is 20 to 30 years.

\section{Potential Applications}

\section{Grid Connected Systems}

Wind turbines can be used to lower the amount of energy required of the grid. The only additional equipment required is an inverter to condition the turbine's electrical output to be compatible with grid power. Batteries are usually not needed.

\section{Remote Sites}

If the average wind speeds at a location are greater than $12 \mathrm{mph}$, a wind turbine may be installed to meet basic electrical needs at a lower cost than extending grid access to remote sites. They are especially useful at offshore sites, where winds are fairly constant. Deep cycle battery systems can supply the owner with reserve power whenever energy demand exceeds that delivered by the wind turbine. A gasoline or diesel generator may be necessary to cover the remaining load. An inverter may be required, depending on the application.

\section{Hybrid Systems}

Hybrid systems are often more effective for remote sites than single systems. Combining PV with a wind turbine can produce more reliable power than either technology alone. Across much of the United States, wind speeds are low in the summer when the sun shines brightest and longest. The wind is strong in the winter, when there is less sunlight. A battery or engine generator can satisfy any additional load.

\section{Benefits}

Wind turbines can provide users with the following advantages:

- zero emissions

- no thermal signature

- zero fuel cost 
- low maintenance

- lower initial costs than PV, the only other completely renewable energy

- very quiet performance (for well maintained turbines).

\section{Drawbacks}

Wind turbines also have the following disadvantages:

- reliance on a variable, unpredictable fuel source

- visually obtrusive

- some controversy regarding the harm this technology may do to migrating birds.

\section{Wind Technology Siting Considerations}

Figure 2, which maps wind distribution in the United States, demonstrates that wind turbines are not cost effective in all areas. Prior to design, study should be done at the intended installation site to determine the speed and constancy of the wind.

\section{Construction Considerations}

\section{Options and Configurations}

Wind turbines can be installed as grid connected, grid independent, or hybrid systems. Turbines can be pitch, active-stall, or passive-stall controlled.

\section{Towers}

The tower supporting the turbine raises it to assure that its blades safely clear the ground and to allow it to reach the stronger winds at higher elevations. Tower height must be the result of a cost-benefit analysis; the higher the tower, the higher the construction cost and energy production. Larger wind turbines are usually mounted on towers ranging from 40 to 70 meters tall. 


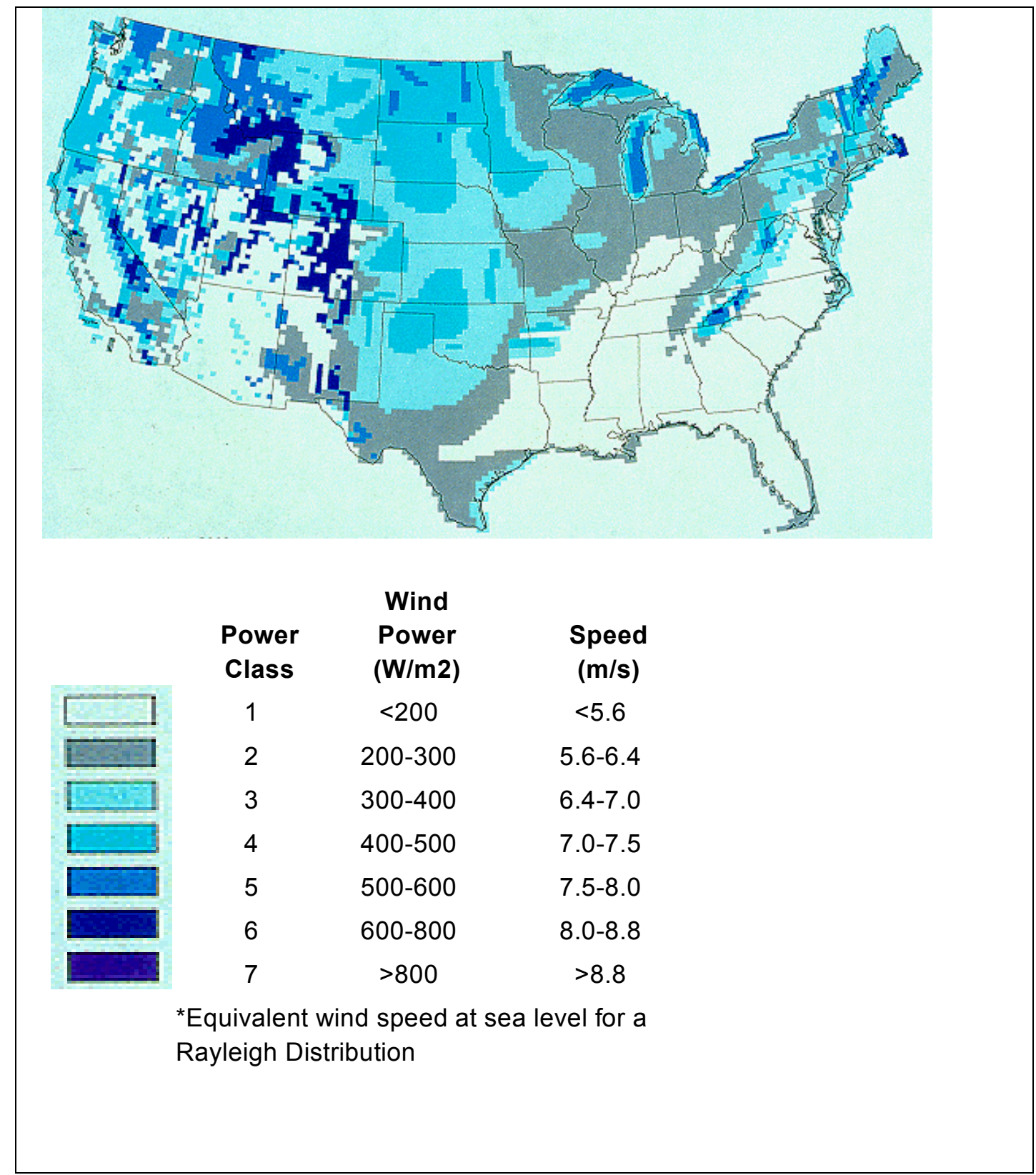

Figure 2. Wind distribution in the United States (courtesy of AWEA).

Towers for small wind systems are generally guyed on three or four sides. These towers cost less than freestanding towers, but require more land area to anchor the guy wires. Some of these guyed towers are erected by tilting them up. Installation can be quickly accomplished using only a winch, with the turbine already mounted to the tower top. This simplifies installation as well as maintenance, and allows the tower to be easily dismantled in the event of a hurricane. Towers can be constructed of a simple tube, a wooden pole, or a lattice of tubes, rods, and angle iron. The structure must be designed not only to support the turbine and subsequent vibrations, but to sustain wind loads itself. 


\section{System Costs}

A turbine package, including the generator and ancillary equipment, costs between $\$ 2500$ and $\$ 7500 / \mathrm{kW}$. Installation adds approximately $\$ 0$ to $\$ 1000 / \mathrm{kW}$, and maintenance adds a small additional amount. Wind energy becomes more cost effective with increasing rotor size.

\section{Siting}

Complex terrains require care in wind turbine siting. Locating the turbine on top of a hill rather than in a gully will provide greater wind access. Geology and other existing obstacles, such as buildings and trees, must be considered, as well as potential future obstacles. The turbine must be at least $30 \mathrm{ft}$ above anything within $300 \mathrm{ft}$ to avoid turbulent wind flows. If a long wire run is required from the turbine to the load, converting from $\mathrm{DC}$ to $\mathrm{AC}$ will decrease transmission losses.

\section{Applicable Codes and Standards}

Local municipal building codes, including height regulations:

International Electrotechnical Commission (IEC)

- IEC 61400-1, Wind Turbine Safety and Design, $2 d$ ed.

- IEC 61400-2, Small Wind Turbine Safety

- IEC 61400-12, Power Performance

- IEC 61400-11, Noise Measurement

- IEC 61400-13, Mechanical Load Measurements

- IEC 61400-22, Wind Turbine Certification

- IEC 61400-23, Blade Structural Testing

- IEC 61400-21, Power Quality

Underwriters Laboratory (UL)

- UL 1741, Inverters, Converters, and Controllers for Use in Independent Power Systems

American Society of Mechanical Engineers (ASME)

- Performance Test Code (PTC) 42, Wind Turbines 


\section{Protection Controls}

\section{Sensors}

One of the most basic safety devices in a wind turbine is the vibration sensor, which is simply a ball resting on a ring. The ball is connected to a switch via a chain. If the turbine shakes too violently, the ball falls off the ring, switching off the turbine. Other sensors monitor the temperatures of the gearbox oil and the generator.

\section{Overspeed protection}

At very high wind speeds, typically between 45 and $80 \mathrm{mph}$, most wind turbines cease power generation and shut down. Shutdown may occur in one of several ways. In some machines, an automatic brake is activated by a wind speed sensor. Some machines twist or "pitch" the blades to spill the wind. Still others use "spoilers," drag flaps mounted on the blades or the hub that are automatically activated by high rotor rotations per minute, or mechanically activated by a springloaded device that turns the machine sideways to the wind stream. Normal wind turbine operation usually resumes when the wind drops back to a safe level.

\section{Aerodynamic tip braking}

Most modern wind turbines use an aerodynamic braking system. Pitch controlled turbines "pitch" the blades to spill the wind when the power output becomes too high. This mechanism is usually hydraulically controlled. Passive stall controlled turbines are aerodynamically complex, relying on slightly twisted blades to ensure stalling occurs gradually rather than abruptly when wind speeds become too high. This structure eliminates the need for moving parts in the rotor and a complex control system. Active stall machines are a hybrid of pitch and passive stall control. If the generator is about to be overloaded, the brakes increase the rotor blades' angle of attack, sending the blades into a deeper stall, wasting excess energy into the wind. Active stall can control power output more accurately than passive stall. This type of braking allows the machine to run at nearly its rated power at all high wind speeds.

\section{Mechanical braking}

Most turbines are also equipped with a mechanical brake, used as a backup for the aerodynamic braking system or to assure safe conditions during maintenance. 


\section{Case Study: Chandalar Lake, AK}

The U.S. Federal Aviation Administration (FAA) operates an aircraft navigation beacon at Chandalar Lake in northeast Alaska, a remote site accessible only by air. In the past, fuel for the diesel generators had to be flown in. The beacon is now powered by two Bergey $7.5 \mathrm{~kW}$ turbines, seen in Figure 3.

The preliminary design that Bergey Windpower Co. (BCW, Norman, OK) developed for the Chandalar Lake project (dated 23 March 1999) is:

1. Wind resources. The location and the altitude $(442 \mathrm{~m})$ correspond to a Class 1 , $>4.4 \mathrm{~m} / \mathrm{s}$ at a height of $10 \mathrm{~m}$, wind zone according to the U.S. Department of Energy (USDOE) World Wind Atlas. The USDOE data for this area of Alaska, however, are based on roof-mounted anemometers and are conservative. The USDOE report states: "The map analyses represent the lower limits of the wind power resource for exposed areas." Therefore, the Chandalar Lake site resource is assumed to be $4.8 \mathrm{~m} / \mathrm{s}(10.8 \mathrm{mph})$ at a height of 10 meters. For the average monthly wind speeds, scaled data from an earlier project at Fort Greely have been used. The Fort Greeley data were based on National Climatic Data Center (NCDC) data.

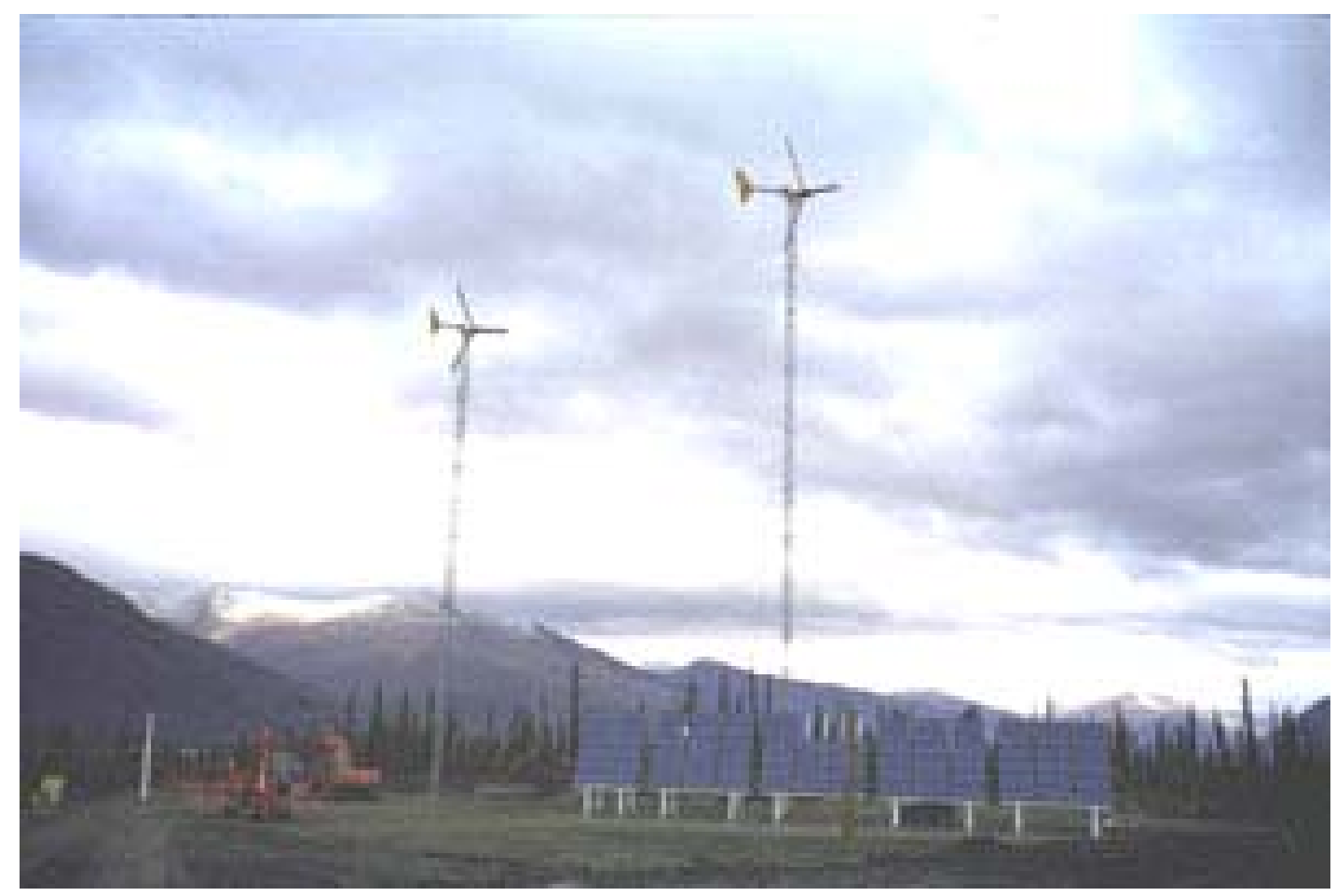

Figure 3. FAA wind turbines at Chandalar Lake. 
2. Solar resources. Solar resource data from Solarex and PVCAD were combined to establish monthly estimates of average daily insolation. The annual average was estimated at $3.4 \mathrm{kWh} / \mathrm{m}^{2}$. The summer resource is usable, but the winter resources are extremely low.

3. Wind turbine and solar array performance. Wind turbine performance predictions are based on the battery-charging version of the BWC excel wind turbine, which has a peak output of 7 to $8 \mathrm{~kW}$. The modeling was done with WindCAD. Please remember that the daily energy predictions are for DC $\mathrm{kWh}$, not $\mathrm{AC} \mathrm{kWh}$, so the losses from storage and power conversion (DC/AC inverter) must be factored in before comparing them to the load or the diesel generation.

The wind turbine performance predictions assume 18-m towers, a Weibull $\mathrm{K}=2$, an altitude of $300 \mathrm{~m}$, a wind shear exponent of 0.143 , and 5 percent losses due to turbulence. Predicted average daily energy production varies from 17 DC $\mathrm{kWh}$ in July to $50 \mathrm{DC} \mathrm{kWh}$ in December.

Solar array performance was modeled for an arbitrary $1 \mathrm{~kW}$ system using first-order (nontemperature compensated) efficiency estimates. The resulting predicted average daily outputs for the $1 \mathrm{~kW}$ array varied from $0.1 \mathrm{kWh}$ in December to $5.8 \mathrm{kWh}$ in May.

The wind and solar resources are good seasonal complements. The wind peaks in the winter and the solar peaks in the summer. In general, however, the wind resources are predicted to be better than the solar resources.

4. Load. The load is a constant $1520 \mathrm{~W}$ AC communications load and a seasonal heating load, which has been calculated from temperature data. Both nondirectional beacon (NDB) and heating loads have been converted to average daily demand by month. All loads are assumed to be 120/240 VAC, $60 \mathrm{~Hz}, 1$-phase.

Following the late spring 1999 conception of installing an all-renewable system and subsequent design process, construction began that summer. The DG system consists of two Bergey $7.5 \mathrm{~kW}$ turbines on $30 \mathrm{~m}$ guyed-lattice towers, a $5 \mathrm{~kW}$ solar array, a 48 VDC sealed battery bank, switchgear, and two Trace sine wave inverters (Xantrex, Burnaby, BC).

The chosen design implemented the least cost wind/solar hybrid capable of supplying a higher percentage of the sites' power on an average basis. The sizing was determined by minimizing the excess production during the high resource months. This system provides 92 percent of the annual energy. A diesel generator meets the remaining energy demand.

The project's logistics posed construction problems due to the site's cold climate. The permafrost precluded onsite concrete pouring so the wind turbine tower anchor blocks had to be precast in Anchorage and flown by C-130 aircraft to Chandalar Lake. The FAA considers Chandalar Lake to be a pilot project and hopes to repli- 
cate it at other off-grid FAA facilities in the coming years. The agency has already purchased two additional smaller systems for other Alaska sites. Table 3 lists some major wind turbine manufacturers.

Table 3. Major wind turbine manufacturers.

\begin{tabular}{|l|l|}
\hline Manufacturer & Web Link (URL) \\
\hline Atlantic Orient & $\underline{\text { http://www.aocwind.net }}$ \\
\hline Bergey WindPower Co. & $\underline{\text { http://www.bergey.com }}$ \\
\hline Bonus Wind Turbine, Texas & $\underline{\text { http://www.bonus.dk }}$ \\
\hline Gamesa & $\underline{\text { http://www.gamesa.es/home.htm }}$ \\
\hline Genergy, Inc. & $\underline{\text { http://www.genergy.com }}$ \\
\hline Lorax Energy Systems, LLC & $\underline{\text { http://www.lorax-energy.com/ }}$ \\
\hline NEG Micon & $\underline{\text { http://www.neg-micon.com/ }}$ \\
\hline Nordex USA, Inc. & $\underline{\text { http://www.nordex-online.com/ }}$ \\
\hline Northern Power Systems & $\underline{\text { http://www.northernpower.com/ }}$ \\
\hline Solar Wind Works & $\underline{\text { http://www.solarwindworks.com }}$ \\
\hline Southwest Windpower & $\underline{\text { http://www.windenergy.com }}$ \\
\hline Synergy Power Corporation & $\underline{\text { http://www.synergypowercorp.com }}$ \\
\hline Toko Asia Enterprises Group & $\underline{\text { http://www.tokoasiausawindturbine.com/ }}$ \\
\hline Vestas Wind Systems & $\underline{\text { http://www.vestas-awt.com/ }}$ \\
\hline WindTech International, LLC & $\underline{\text { http://www.windmillpower.com }}$ \\
\hline Wind Turbine Company & $\underline{\text { http://www.windturbinecompany.com/ }}$ \\
\hline Wind Turbine Industries Corporation & $\underline{\text { http://www.windturbine.net }}$ \\
\hline Wintec Energy, Ltd. & $\underline{\text { http://www.wintecenergy.com/ }}$ \\
\hline
\end{tabular}




\section{Microturbines}

\section{Background}

British and German engineers developed the first working gas turbines in the 1930s. The early models were large, produced only moderate amounts of thrust, and were complex and rather unreliable. The development of high strength, heat resistant alloys and new machining methods has allowed for the downscaling of the turbine. Inconel, stainless steel, and ceramic hybrid bearings are commonly used in all microturbines. Microchip technology allows for the very consistent, smooth, and safe operation of the present day gas turbine.

In the early 1990s the first successful commercial microturbines were produced and made available. Using only propane to start and operate, the units were capable of producing 11 pounds of thrust. These engines were complex, heavy, had very slow throttle transition, and required large propane supplies.

During this period of propane-powered turbines, European engineers began designing a lightweight, high output liquid-fueled gas turbine. Refinements to the turbine and electronics have resulted in engines that can be started by the push of a single button rather than extensive manipulation of a fuel and air mixture.

Today's turbines are self-starting, self-diagnosing, and failsafe. They are lightweight and capable of producing more thrust than their recent, larger, more complicated predecessors. The microturbine has been proven to be a reliable, compact, powerful alternative to the internal combustion engine. Microturbines have powered cars and functioned as Auxiliary Power Units (APUs) in aircraft and missiles. In the late 1960s the telephone industry began using microturbines to create power for remote sites. Now they are finding a niche in the DG market.

\section{Technology Overview}

The microturbine typically runs on a Brayton cycle at 68,000 rpm and higher in the 30 to $400 \mathrm{~kW}$ range. In this cycle, atmospheric air is first compressed, then fuel combustion heats the compressed air. The heated air-fuel mixture is expanded through a turbine (Figure 4) rotating the blades, and then exhaust gases are dis- 
charged into the atmosphere. In most cases, a high-speed permanent magnet generator converts the rotation into electricity, variable voltage, variable frequency AC power.

Two types of bearing systems are used in microturbines. Air bearings eliminate the oil system, and so require little maintenance and have no parasitic oil pump load. Oil bearings, however, last longer.

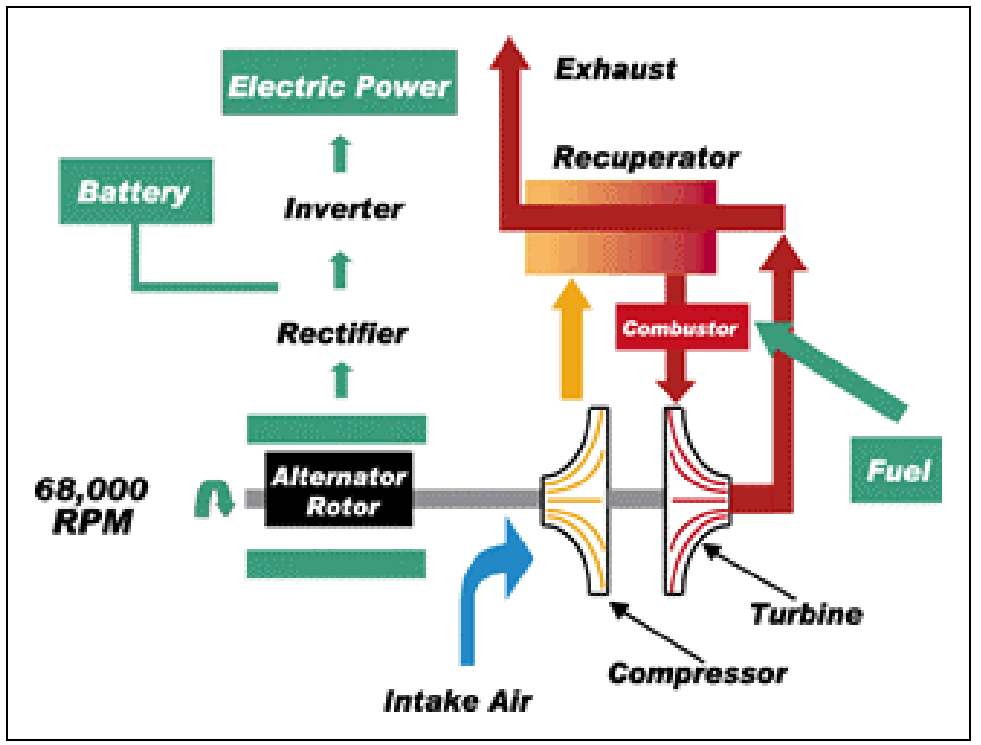

Figure 4. Recuperated microturbine block diagram (courtesy of Elliot Energy Systems).

\section{Efficiency}

Often a recuperator is used to capture exhaust gases to preheat the combustor inlet air, improving efficiency to 20 to 30 percent compared with the 14 to 20 percent of nonrecuperated units. Microturbine efficiency also increases with increasing gas pressures. A 1 to 4 percent improvement can be expected with high-pressure gas at 50 to 60 psig. Combining the microturbine with a high temperature fuel cell, running the fuel cell's waste heat through the turbine to produce additional electricity, can increase the system's efficiency to more than 60 percent. Figure 5 is an example of a microturbine. 


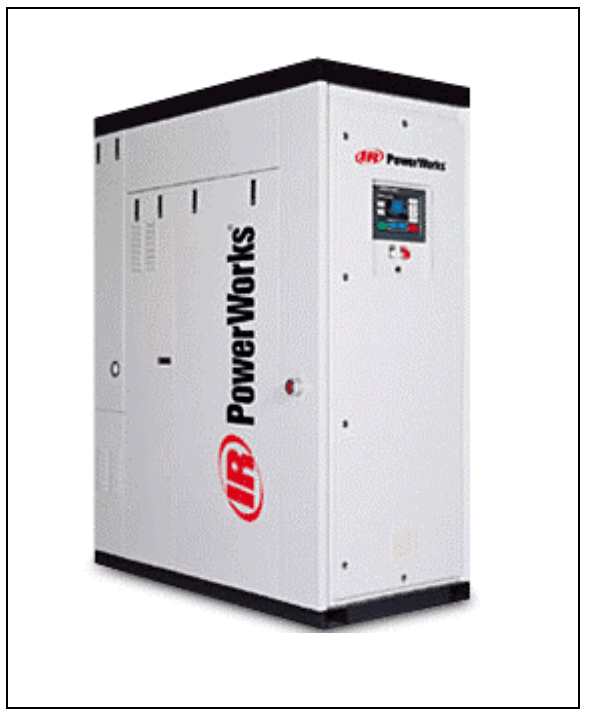

Figure 5. IR PowerWorks microturbine.

\section{Types}

The two main types of microturbine are single shaft and double shaft. Single shaft machines are simpler to design and have a lower capital cost, but double-shaft microturbines offer several advantages. An inverter is required to convert the power produced by the generator on a single-shaft microturbine from AC power to $60 \mathrm{~Hz}$ DC power. Two-shaft configured microturbines include a reduction gearbox and generator, so no inverter is required. The two-turbine configuration increases engine life by splitting work output between the turbines. Because of its direct mechanical output, the dual turbines can drive any rotating mechanical component. Greater component flexibility is afforded over a single-shaft microturbine. Because the power components of the dual shaft rotate at a lower speed, catastrophic rotating failures are less dangerous; resulting shrapnel moves much more slowly.

\section{Emission Control}

Microturbine emissions are similar to those of larger turbines. The $30 \mathrm{~kW}$ Capstone unit produces nitrous oxide (NOx) levels less than 9 parts per million (ppm), though emissions increase when the turbine is run under partial loads. Combustor design and flame control technologies are often employed as methods of emission control. Because of their small size, many microturbine installations are exempt from emission regulations. 


\section{Potential Applications}

\section{Resource Recovery}

Biogases are zero-cost fuel sources that are often wasted. Microturbines can draw energy from them resulting in extremely low emissions. Excess oil and gas is frequently flared, a highly polluting practice, but microturbines can burn these resources for energy rather than wasting them to the atmosphere.

\section{Cogeneration}

Cogeneration can increase the efficiency of microturbines to nearly 90 percent by using heat produced by a microturbine for direct or indirect heating and cooling. Because much of the heat output is used for inlet air preheating, the recuperation needed for higher electric efficiencies limits the quality of thermal output.

\section{Grid-Connected Systems}

When the existing electrical infrastructure is no longer able to handle given loads, microturbines can be added to make up the difference, often at a lower cost than expanding the grid's capabilities. Because of their low capital cost, microturbines can be suitable for peak shaving. They can also be used as standby power in the case of a grid failure to prevent crucial applications from losing power.

\section{Grid-Independent Systems}

Microturbines can provide power to remote sites where the grid is not accessible but, because of their low efficiencies, fuel costs will likely be lower with the use of an alternative DG source.

\section{Benefits}

Microturbines can offer users the following benefits:

- fuel flexibility

- lower emissions than other combustion processes - NOx less than 9 ppm

- use of air bearings, which are low maintenance

- can be operated continuously or for peak shaving or back-up power

- can use combined heat and power

- ability to operate grid-connected or independently

- scalability

- can be inexpensively mass-produced 
- can operate over a wide power range

- responsiveness to sudden load changes

- small footprint.

\section{Drawbacks}

However, microturbine technology has the following drawbacks:

- uses combustion; therefore creates emissions

- obtaining higher efficiency requires heat recovery

- efficiency drops with increase in altitude

- low efficiency causes higher fuel costs

- long startup time limits use as backup power.

\section{Operation and Maintenance Considerations}

Generally, microturbines are designed to operate for 100 cycles or more before requiring a preventative bearing change. Ensuring fresh fuel is used, maintaining equipment, and using proper starting procedures will ensure a healthy engine that will give years of reliability. Common problems stem from using old, contaminated fuel, leaking fuel lines, plugged filters, and poorly designed ducting systems.

The following is an example maintenance schedule for a Capstone $30 \mathrm{~kW}$ microturbine (Figure 6):

- microturbine air filter, replace every $8000 \mathrm{hr}, \sim \$ 100$

- air filter electronics, replace every $8000 \mathrm{hr}, \sim \$ 80$

- internal fuel filter, inspect every $8000 \mathrm{hr}$, labor only

- external fuel filter, replace every $8000 \mathrm{hr}, \sim \$ 200$

- turbine exhaust thermocouple, replace every $16,000 \mathrm{hr}, \sim \$ 120$

- igniter, replace every $16,000 \mathrm{hr}, \sim \$ 225$

- three injectors, replace every $16,000 \mathrm{hr}, \sim \$ 1600$

- rotary flow compressor, replace every 3 to $16 \mathrm{khr}, \sim \$ 2700$ 


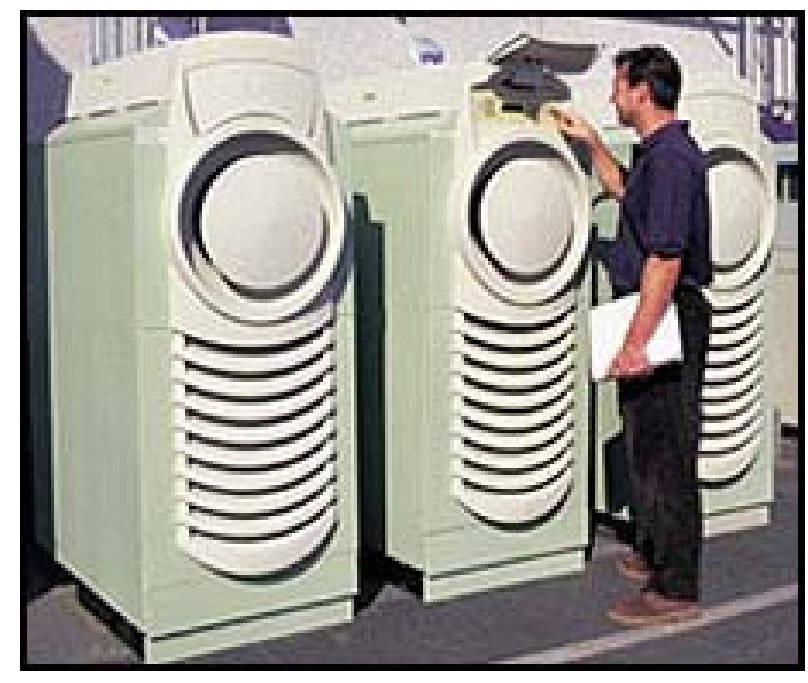

Figure 6. Capstone microturbines.

\section{Fuel Considerations}

The preferred fuel for use in microturbines is natural gas because of the fuel's large distribution networks and the lower emission levels produced when burning it compared to other combustibles. Many microturbines are also capable of running on liquefied petroleum gas (LPG), diesel, kerosene, Jet-A and bio-diesel. Systems can be designed to operate on fuels with British thermal unit (Btu) content as high as propane, $2500 \mathrm{Btu} /$ standard cubic foot (SCF), or natural gas, $1000 \mathrm{Btu} / \mathrm{SCF}$, and as low as digester gas, $600 \mathrm{Btu} / \mathrm{SCF}$, or landfill gas, 350 to $500 \mathrm{Btu} / \mathrm{SCF}$.

\section{Construction Considerations}

\section{Options and Configurations}

Microturbines, single or double shaft, can be designed to perform resource recovery or operate with any number of available fuels. They can be set up in cogeneration systems, grid connected, grid independent, or a hybrid of the two. Microturbines can operate in parallel with other DG systems or linked to other microturbines.

\section{System Costs}

The initial cost of a microturbine system depends on its rating, ranging from $\$ 700$ to $\$ 1100 / \mathrm{kW}$. For instance, a $30-\mathrm{kW}$ Capstone unit is priced at about $\$ 33,000$, while a $60-\mathrm{kW}$ unit is about $\$ 50,000$. The cost of operating a microturbine depends upon the configuration of the system. Adding CHP capabilities, for example, increases 
the unit's cost from $\$ 75$ to $\$ 350 / \mathrm{kW}$. Installation generally adds 30 to 50 percent to the total cost, and maintenance can be expected to run approximately $\$ 0.01$ to $\$ 0.015 / \mathrm{kWh}$ annually.

\section{Applicable Codes and Standards}

\section{American Society for Testing and Materials (ASTM) International}

- D2880-00, Standard Specification for Gas Turbine Fuel Oils

- D4418-00, Standard Practice for Receipt, Storage, and Handling of Fuels for Gas Turbines

- D6224-98, Standard Practice for In-Service Monitoring of Lubricating Oil for Auxiliary Power Plant Equipment

- D6522-00, Standard Test Method for Determination of Nitrogen Oxides, Carbon Monoxide, and Oxygen Concentrations in Emissions from Natural Gas-Fired Reciprocating Engines, Combustion Turbines, Boilers, and Process Heaters Using Portable Analyzers

- D396-01, Standard Specification for Fuel Oils

\section{American Society of Mechanical Engineers (ASME)}

- B133.4, Gas Turbine Control and Protection Systems

- B133.7M, Gas Turbine Fuels

- B133.8, Gas Turbine Installation Sound Emissions

- 3977-1, Gas Turbines: Procurement-Part 1: General Introduction and Definitions

- 3977-2, Gas Turbines: Procurement-Part 2: Standard Reference Conditions and Ratings

- B133.9, Measurement of Exhaust Emissions From Stationary Gas Turbine Engines

- B133.3, Procurement Standard for Gas Turbine Auxiliary Equipment

- B133.5, Procurement Standard for Gas Turbine Electrical Equipment

- B133.10, Procurement Standard for Gas Turbine Information To Be Supplied by User and Manufacturer

- B133.12, Procurement Standard for Gas Turbine Maintenance and Safety

- B133.11, Procurement Standard for Gas Turbine Preparation for Shipping and Installation

\section{National Fire Protection Association (NFPA)}

- NFPA 37, Standard for the Installation and Use of Stationary Combustion Engines and Gas Turbines 


\section{Case Study: Fort Drum, NY}

A USDOE and Federal Energy Management Program (FEMP) grant, awarded in April 2001, funded a microturbine demonstration project at Fort Drum, NY. Construction began in December 2001 and was completed by May 2002. The site includes a 119,000 sq-ft 500-soldier barracks, an administration complex with a full dining hall, and a domestic hot water (DHW) requirement of over 8800 therms/ month. The microturbine was installed inside the boiler room, connected to a dedicated DC (DDC) system for load control. The Capstone Model 330 microtubine pictured in Figure 7 provides $30 \mathrm{~kW}$ of power at $208 \mathrm{~V}$ for emergency backup of the boiler room equipment, as well as heat for the site's DHW.

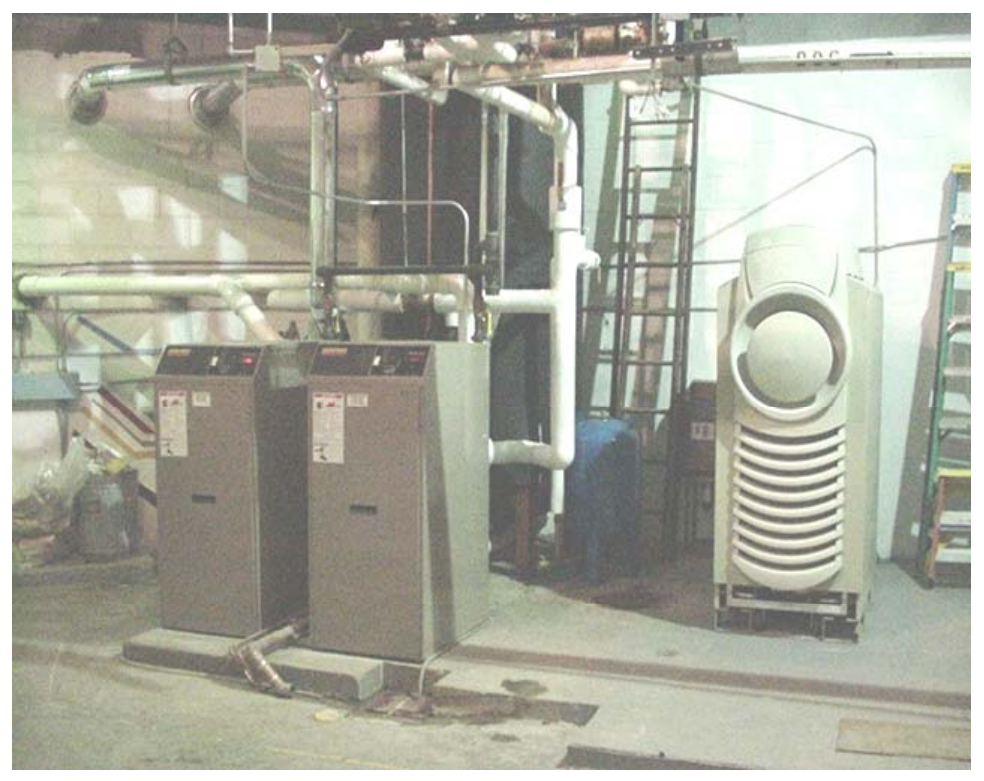

Figure 7. Fort Drum microturbine and DHW heaters.

\section{Electrical Design}

The installed generator provides 480V 3-phase power, so a step down transformer was required to provide $208 \mathrm{~V}$ service. The system was set up such that in the event of a grid outage, the microturbine would shut down and open the grid isolation switch, restarting after a brief pause. A Trane Tracer 100 DDC control system sequentially starts the following boiler room equipment in 3-minute intervals: a 2 million Btu (Mbtu)/hr hydronic boiler, a DHW boiler, boiler-room lights, one DHW circulating pump, and a 15 horsepower (hp) main circulation pump. 


\section{Mechanical Design}

The microturbine exhaust was ducted through a Unifin plate-type heat exchanger (Unifin International, Inc., London, Ontario), providing heat for the site's DHW through a closed loop circulation system with a 2040 -gal storage capacity. The heat recovery system operates at $240,000 \mathrm{Btu} / \mathrm{hr}$, heating water to $140^{\circ} \mathrm{F}$. Once the set temperature of the DHW is reached, a diverter opens, forcing the exhaust directly to the exhaust stack until the DWH requires further heating.

\section{Major Microturbine Manufacturers}

Table 4 lists some microturbine manufacturers and contact information.

Table 4. Microturbine manufacturers.

\begin{tabular}{|l|l|}
\hline Manufacturer & Web Link (URL) \\
\hline ALM Turbine, Inc. & http://www.miniturbine.com \\
\hline Bowman Power Ltd. & http://www.bowmanpower.com \\
\hline Capstone Turbine Corp. & http://www.microturbine.com \\
\hline DTE Energy & http://www.dteenergy.com \\
\hline Elliott Energy Services & http://www.elliottenergy.ca/ \\
\hline Honeywell & http://www.honeywell.com \\
\hline Ingersoll-Rand & http://www.irco.com \\
\hline Turbec Americas Inc. & http://www.turbec.com \\
\hline
\end{tabular}




\section{Stirling Engines}

\section{Background}

The Reverend Robert Stirling patented the Stirling engine in 1816, well before Sadi Carnot began the development of thermodynamics. Stirling's efforts to develop the device were motivated by the frequent explosions of steam engine boilers. Steel and Bessemer iron were not yet available, and the low strength materials used for the boilers often exploded, leaving many people working near them severely burned by high-pressure steam. Stirling's engine did not explode because the pressures were not highly elevated. The machine simply stopped when the heater section failed from thermal stress or imperfections in the material or manufacturing process.

Since Stirling's time, his engines have continued to quietly evolve, though they have not managed to gain a firm foothold in the market. Stirling engines are impractical for many applications because the heat source is external. The engine must warm up before it can respond to changes in the amount of heat being applied to the cylinder and produce useful power. The engine is not able to quickly change its power output; however, in cases where it would not need to be shut down and restarted frequently, such as a distributed energy power source, the engine can efficiently convert any source of heat into electricity.

\section{Technology Overview}

A Stirling engine is a closed-cycle, regenerative heat engine that uses an external combustion process, heat exchangers, pistons, a "regenerator," and a gaseous working fluid contained within the engine to convert heat to mechanical work.

The displacer and power piston reciprocate in a cylinder filled with a fixed charge of working gas, typically helium. The engine proceeds through the Stirling cycle, detailed in Figure 8, which involves the four phases shown in the figure. When the working gas is heated, its pressure increases, pushing the piston, forcing the hot gas into the cool cylinder. As the gas cools, its pressure decreases, allowing atmospheric pressure to push the piston back down. This process repeats rapidly, and the mechanical work performed can be converted to usable energy. The two main ways to raise the power output of a Stirling cycle are to increase the pressure in the first 
phase by increasing the temperature or to cool the gas in the third phase to a lower temperature. Due to heat transfer and mechanical issues, most Stirling engines currently available have capacities under $5 \mathrm{~kW}$.

\section{Types}

The two main types of Stirling engines are kinematic and free piston. The kinematic engine has pistons attached to a drive mechanism that converts the linear motion of the pistons to a rotary motion. Because they have a crankshaft and flywheel, kinematic engines may replace internal combustion engines to provide shaft power. The free piston engine uses harmonic motion mechanics and usually planar springs. The pistons are mounted in flexures and oscillate freely, without any contact, and therefore without any wear. They can be configured to provide whatever voltage and frequency are required. Hundreds of variations of these two types of engines can be used, depending on the application.

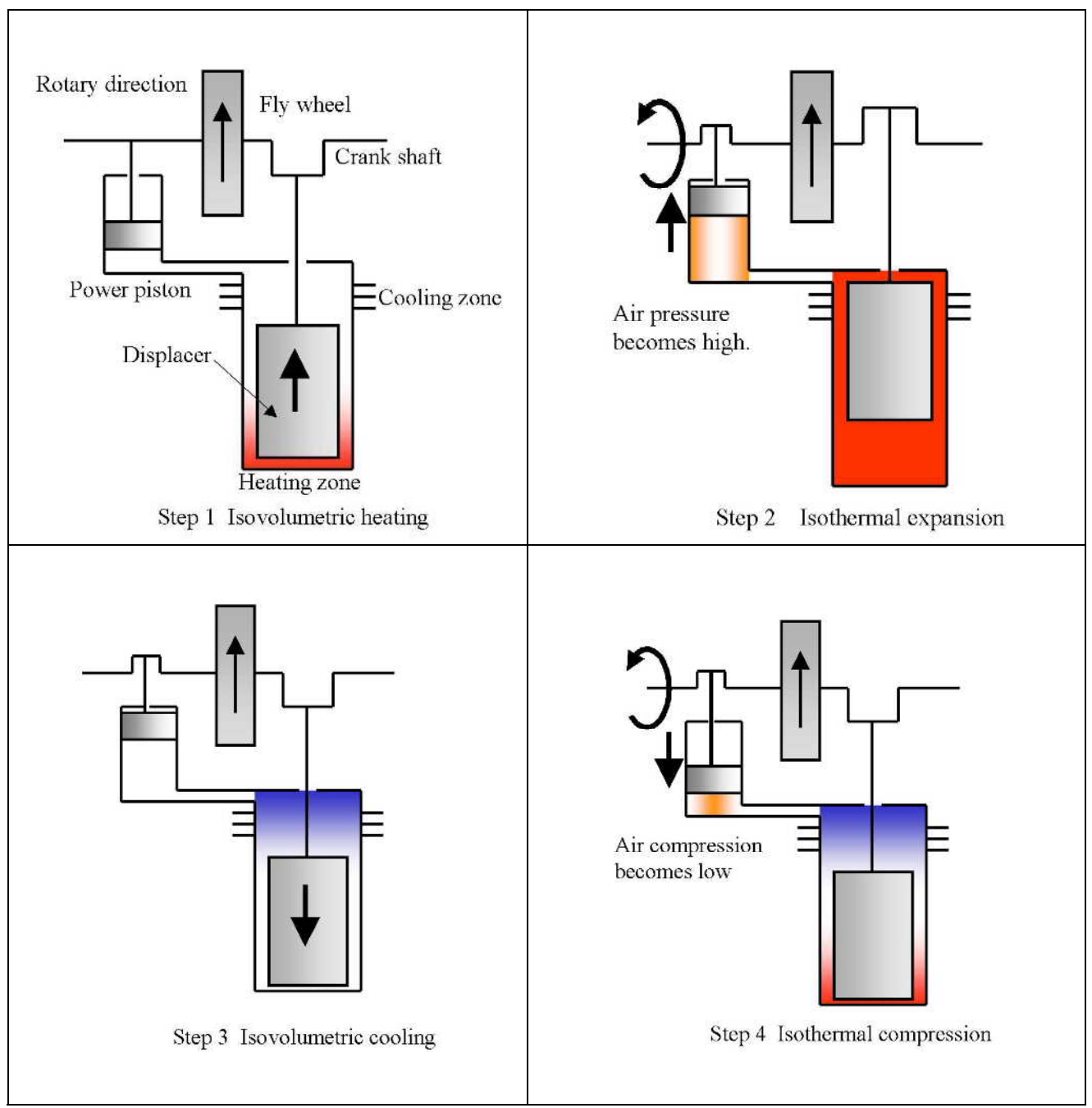

Figure 8. The Stirling cycle (courtesy of J. Shinozuka). 


\section{Efficiency}

Stirling engines can reach 50 percent of their maximum theoretical output, which increases to 98 percent when the engine is used in cogeneration. Their theoretical efficiency is nearly equal to their theoretical maximum efficiency or Carnot Cycle efficiency.

\section{Potential Applications}

Stirling engines can be used as grid-connected or independent generators, or in specialized applications. Because they make little noise, they can be used to create electricity on submarines.

Stirling engines can be coupled with any heat generating process, such as burning a fuel for direct use or drawing on waste heat from another process, the latter increasing the efficiency of electrical production. For instance, the engine may be used in conjunction with fuel cells, making use of the byproduct heat, or in facilities where steam is created and typically wasted.

\section{Benefits}

Stirling engines offer the following benefits:

- quiet operation

- a physically small size

- high reliability

- long life

- maintenance-free operation

- zero emissions

- fuel flexibility

- recovery of waste heat created by other processes.

\section{Drawbacks}

However, Stirling engines also have the following drawbacks:

- a long startup time

- cannot quickly change power output

- high capital costs

- larger than internal combustion engines with similar power output. 


\section{Construction Considerations}

\section{Options and Configurations}

Stirling engines can be used as grid-connected or independent energy sources. To minimize the size and cost of a battery bank, an off-grid engine should be run continuously, charging the bank to handle peak loads beyond the engine's capacity. An inverter can be used to obtain $\mathrm{AC}$ power from the batteries. In grid-connected situations, it is practical to turn the generator on and off as loads reach prescribed levels. Thus power is produced when it is most needed or most cost effective.

Stirling engines can be coupled with any heat generating process, increasing the efficiency of electrical production. For instance, they may be used in conjunction with fuel cells (making use of the waste heat from the fuel cells) or in facilities where steam is created and typically wasted.

\section{Heliostats}

Heliostats, or solar concentrators, can be used to collect heat to power Stirling engines. They use a lens or reflectors to concentrate sunlight (Figure 9). They can use only direct sunlight, so they must track the sun precisely and do not work when it is cloudy. A heliostat can make the Stirling engine a completely renewable energy source, so fuel costs are zero. Because this system produces electricity only on sunny days, it must be used with a battery bank or alternate power generator or be connected to the grid. In the United States, the heliostat Stirling system would be effective only in the southwest.

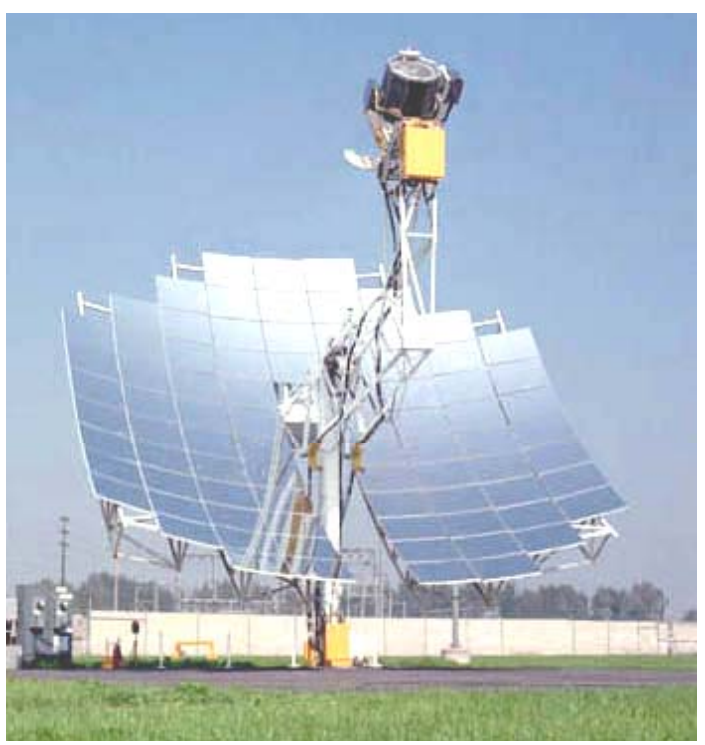

Figure 9. Solar Dish Stirling system (courtesy of SES). 


\section{Ancillary Equipment}

An alternator of some sort is required to turn the mechanical energy generated by the engine into electricity. For instance, induction generators are used on gridconnected kinematic Stirling engines. They are about 94 percent efficient, synchronize with the grid, and provide single or three-phase power of either 230 or $460 \mathrm{~V}$.

An inverter may be necessary for further power conditioning. A radiator is required to allow the Stirling engine to waste excess heat to the atmosphere.

\section{Fuel Considerations}

Stirling engines may be operated using propane, natural gas, gasoline, diesel, radioisotopes, solar energy, or biomass. They can be coupled with any heat generating process.

\section{System Costs}

Stirling engines are not yet mass produced. Prototypes are available, however. Early commercial engines will have higher initial costs than internal combustion generators, but the Stirling is more cost effective over its lifetime. High efficiency and low maintenance make the engine competitive with other DG technologies.

\section{Case Study: Pima-Maricopa Indian Reservation, AZ}

The Science Applications International Corporation (SAIC) and STM Corporation, in conjunction with the USDOE and Salt River Project, have been operating a Stirling engine/solar dish at the Pima-Maricopa Indian Reservation landfill in Arizona since mid-1999. The concentrator (Figure 10), has 16 round, stretched-membrane mirror facets, amounting to a total reflective area of $118 \mathrm{~m}^{2}$. Concentrated sunlight from the dish enters a cavity receiver and encroaches upon a direct-irradiation receiver containing hydrogen working fluid. The Stirling engine has four axial cylinders in a square configuration, with a swashplate drive to the output crankshaft. The engine runs at $2200 \mathrm{rpm}$ and drives a standard three-phase generator at 1800 rpm through a reduction geartrain. The engine is set up to burn gaseous fuel to produce power at night or anytime the sun is obscured. The landfill gas collection system at the site provides the fuel. Operation of the SunDish is fully automated. Its control system includes a microprocessor-based dish controller and engine. A central control computer allows for remote operation. The system is also set up to 
collect data on its performance. It automatically wakes up, tracks the sun, and transitions between solar and gas operation.

The Stirling engine requires daily verification of hydrogen pressures and other periodic maintenance. The dish must be cleaned once per month, have its clock synchronized once per week, and be inspected on a regular basis.

Since its installation, the SunDish has operated on sun power for over $580 \mathrm{hr}$ and has delivered over 7.1 MW-h of electricity to the grid, peaking at $22.4 \mathrm{~kW}$ at 20 percent efficiency. It has facilitated improvements in Stirling engine/solar dish grid interfacing, dish and engine control systems, maintenance procedures, and robustness.

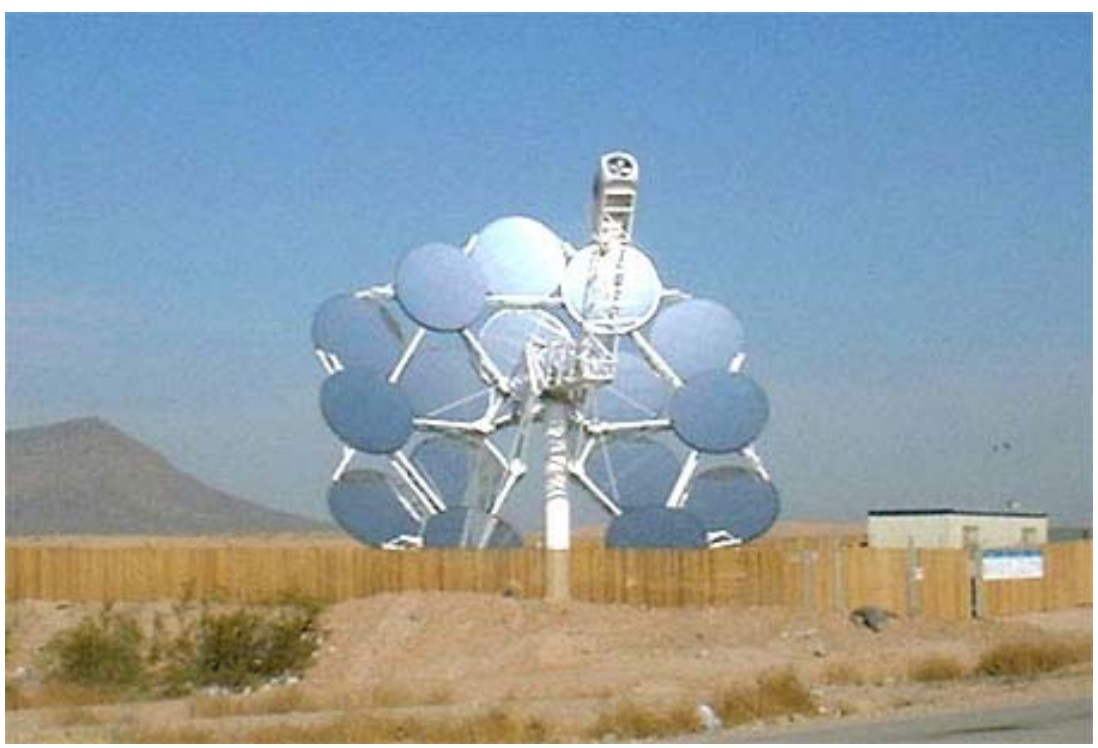

Figure 10. Pima-Maricopa Indian Reservation SunDish (courtesy of DOE).

\section{Major Stirling Engine Manufacturers}

Table 5 lists some Stirling engine manufacturers and contact information.

Table 5. Stirling engine manufacturers.

\begin{tabular}{|l|l|}
\hline \multicolumn{1}{|c|}{ Manufacturer } & \multicolumn{1}{c|}{ Web Link (URL) } \\
\hline American Stirling Company & http://www.stirlingengine.com \\
\hline DEKA Research and Development Corp. & http://www.dekaresearch.com \\
\hline Quiet Revolution Motor Company, LLC & http://www.qrmc.com \\
\hline Stirling Advantage, Inc (SAI) & http://www.stirlingadvantage.com \\
\hline Stirling Energy Systems, Inc (SES) & http://www.stirlingenergy.com \\
\hline Stirling Technology Company (STC) & http://stirlingtech.com \\
\hline Stirling Technology, Inc & http://www.stirling-tech.com \\
\hline STM Power & http://www.stmpower.com \\
\hline Whisper Tech Ltd & http://www.whispertech.co.nz \\
\hline
\end{tabular}




\section{Fuel Cells}

\section{Background}

In 1838 English scientist William Robert Grove was recognized for his development of an improved wet-cell battery. The Grove Cell used a platinum electrode immersed in nitric acid and a zinc electrode in zinc sulfate to generate about 12 amperes (amps) at about 1.8 volts. Grove discovered that, by arranging two platinum electrodes with one end of each immersed in sulfuric acid and the other ends separately sealed in containers of oxygen and hydrogen, a constant current would flow between the electrodes. Each container also held water, and Graves noticed that the water level rose in both tubes as the current flowed. Electrolysis, the process of using electricity to decompose water into hydrogen and oxygen, had been discovered in 1800. Grove set out to reverse the process to produce electricity, and soon accomplished this feat with the device he named a "gas battery," now known as the first fuel cell, by combining several of the electrodes in a series circuit.

In 1889 Chemist Ludwig Mond built a hydrogen-oxygen fuel cell that attained 6 amps per square foot (measuring the surface area of the electrode) at 0.73 volts. His cell used electrodes of thin, perforated platinum. Four years later, Friedrich Wilhelm Ostwald experimentally determined the interconnected roles of the various components of the fuel cell: electrodes, electrolyte, oxidizing and reducing agents, anions, and cations, and was able to explain theoretically how fuel cells work. In 1939 Francis Thomas Bacon built a cell that used nickel gauze electrodes and operated under pressures as high as 3000 psi. In 1958 Bacon demonstrated an alkali cell using a stack of 10-in. diameter electrodes, technology that proved reliable enough to be used on the Apollo spacecraft.

The National Aeronautic and Space Administration (NASA) continues to use fuel cells on all their missions. This promising technology is still evolving, bringing developers closer to building units commercially available on a wide scale.

\section{Technology Overview}

Though there are many different types of fuel cells, the basic operating principles for all are the same. An electrolyte separates two electrodes: an anode and a cath- 
ode. Hydrogen enters the anode (Figure 11), while oxygen from the air passes into the cathode. A catalyst splits the hydrogen into a proton and an electron. The protons travel through the electrolyte to the cathode. The electrons cannot pass through the membrane, so they must flow through an external circuit, creating a DC circuit. The electrons end up at the cathode, where they combine with the hydrogen and oxygen. Heat and water are thus produced. A fuel cell is made up of "stacks" of numerous electrode/electrolyte "cells."

Several types of fuel cell technologies are now being developed, including proton exchange membrane (PEM), alkaline (AFC), phosphoric acid (PAFC), solid oxide (SOFC), and molten carbonate (MCFC).

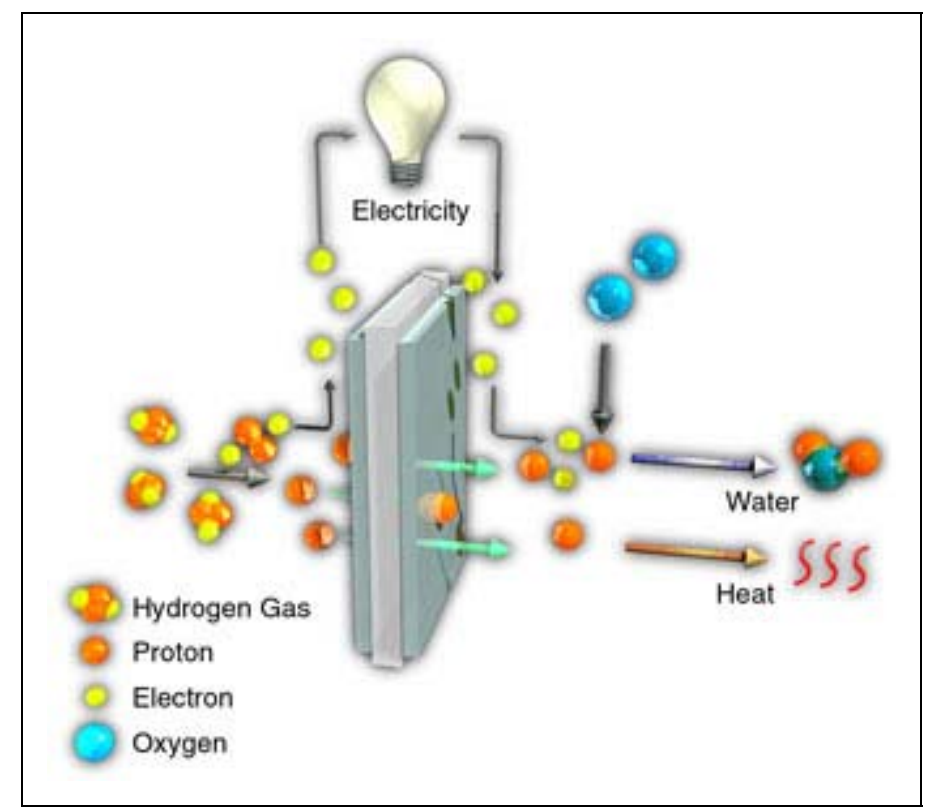

Figure 11. Fuel cell schematic (courtesy of Plug Power).

\section{PEM}

PEM fuel cells use a polymer electrolyte in the form of a thin, permeable sheet made of polyperfluorosulfonic acid. At around $200^{\circ} \mathrm{F}$, the PEM operates at low temperatures relative to other types of fuel cells. Even with higher cost platinum catalysts, PEM cells can be manufactured less expensively than other types of fuel cells. They are practical in small-scale applications, have high power density, and can vary their output quickly to meet shifts in power demand. The output from PEM cells ranges from $500 \mathrm{~W}$ to $250 \mathrm{~kW}$. 


\section{$A F C$}

AFCs also require platinum electrode catalysts, but operate at a somewhat hotter temperature (300 to $\left.400^{\circ} \mathrm{F}\right)$ than PEM cells and are about 70 percent efficient. They typically use a solution of potassium hydroxide (chemically, $\mathrm{KOH}$ ) in water as their electrolyte. AFCs can produce $300 \mathrm{~W}$ to $5 \mathrm{~kW}$ of power. They provided electricity and drinking water on the Apollo space missions.

\section{PAFC}

PAFCs also require platinum electrode catalysts and operate in the 300 to $400{ }^{\circ} \mathrm{F}$ range. They use phosphoric acid as an electrolyte. Their efficiency varies between 40 and 80 percent, and they can tolerate carbon monoxide concentrations of up to 1.5 percent, broadening the choice of fuels they can use. PAFCs can produce up to $200 \mathrm{~kW}$ of power.

\section{SOFC}

SOFCs use a hard, ceramic compound of metal, such as calcium or zirconium, oxides as an electrolyte. They are nearly 60 percent efficient and run at around $1800^{\circ} \mathrm{F}$. Their high temperatures limit their applications, but eliminate the need for a fuel reformer and afford a greater opportunity for heat recovery than other types of fuel cells. SOFCs are capable of producing up to $100 \mathrm{~kW}$ of power.

\section{MCFC}

MCFCs use compounds of salt carbonates electrolytes. Their nickel electrode catalysts are far less expensive than the platinum used in other types of fuel cells. They operate at around $1200^{\circ} \mathrm{F}$ with 60 to 80 percent efficiency. Their high temperatures limit their use but again create a valuable opportunity for waste heat recovery. Because of certain electrochemical reactions in the cell, carbon dioxide must be injected during operation. Current MCFCs are capable of producing up to $2 \mathrm{MW}$ of power.

\section{Potential Applications}

\section{Grid-Connected Systems}

Fuel cells can be configured to provide primary power or true premium power as a backup during grid failures. 


\section{Remote Sites}

Fuel cells can be installed in locations too far off the grid to be served by ordinary utilities, provided a fuel source is available. The lack of emissions makes fuel cells ideal for sites requiring minimal environmental disturbance. Their lack of moving parts increases availability, making them suitable for continuous use. High efficiencies keep fuel costs low.

\section{Cogeneration}

Heat is a byproduct of all fuel cells. Adding a heat exchanger to capture this waste heat for use in water heating, boiler makeup, or space heating or cooling can increase the system's efficiency to over 80 percent. The waste heat could also be recovered for use in a microturbine for further power generation.

\section{Benefits}

The benefits of fuel cell technology are that the technology:

- has no moving parts

- produces little noise

- produces only heat and water as by-products

- has great siting flexibility (because of its low emissions)

- is "stackable" (i.e., users can add capacity as funding becomes available Figure 12).

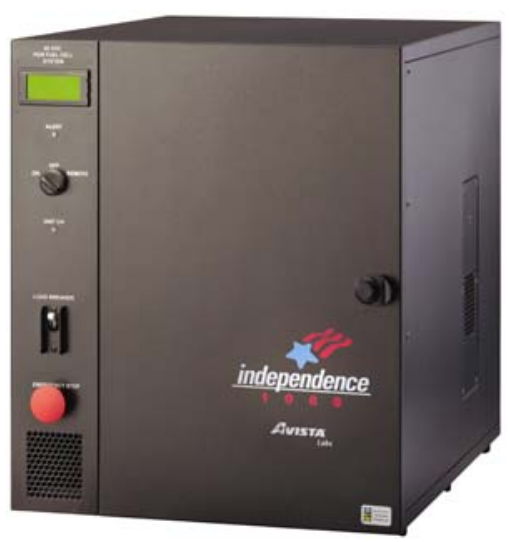

Figure 12. Avista Labs' 1 kW PEM fuel cell (courtesy of Avista Labs). 


\section{Drawbacks}

Fuel cell technology does, however, have the following drawbacks:

- high cost

- no hydrogen fuel infrastructure in place

- efficiency is lost when fossil fuels are reformed to produce hydrogen

- sulfur must be removed from the fuel to avoid poisoning the cell

- stack degrades over time, requiring expensive replacement

- fuel cell units have long startup times

- frequent startups/shutdowns negatively affect fuel cells.

\section{Fuel Considerations}

Fuel cells can be configured to acquire their hydrogen from numerous sources. Systems including a fuel reformer can draw hydrogen from any hydrocarbon fuel: natural gas, ethanol, methanol, gasoline, diesel, landfill gas, or anaerobic digester gas from wastewater treatment plants. To be a completely green energy source, fuel cells can be coupled with wind turbines or PVs, which can be used to electrolyze water to obtain hydrogen.

\section{Construction Considerations}

\section{Options and Configurations}

If the fuel cell is to be set up for heat recovery, it should be interfaced with a thermal loop that has a lower temperature than that of the fuel cell's delivery temperature.

Because a fuel cell's efficiency degrades over time, a higher input fuel rate will eventually be required. This must be taken into account when the fuel piping is installed.

The fuel cell should be sited as close as possible to the electrical, thermal, and natural gas interfaces it will be using. This proximity will not only reduce the cost of wire and pipe runs, but will minimize energy losses as well.

A mounting slab appropriate for the weight of the fuel cell must be provided. If the cell is to be installed indoors, provisions must be made for an air supply and exhaust. 


\section{System Costs}

Today's typical fuel cells cost about $\$ 4500 / \mathrm{kW}$. Installation adds an additional $\$ 800 / \mathrm{kW}$. Heat exchangers, chillers, and transformers further increase the cost. Maintenance and fuel rates must also be considered.

\section{Applicable Codes and Standards}

American National Standards Institute (ANSI)

- ANSI B31.1, Pressure Piping Code

- ANSI 7-95, Minimum Design Loads

\section{American Gas Association (AGA)}

- 8-90, Requirements for Fuel Cell Power Plants

\section{ASME}

- ASME Boiler and Pressure Vessel Code, Sections VIII and IX

NFPA

- NFPA 70, National Electric Code

- NFPA 86C, Standards for Industrial Furnaces

- NFPA 101, Life Safety Code

- NFPA 30, Flammable and Combustible Liquids Code

- NFPA 853, Standard for the Installation of Fuel Cells

$U L$

- UL 795, Commercial Industrial Gas Heating Equipment

Occupational Safety and Health Administration (OSHA)

- General Industry Standards, 29 CFR 1910.212

\section{Electric Distribution System Considerations}

If the fuel cell's output voltage is not available at the connected load, it must be interfaced with an intermediate step up or step down transformer. 


\section{Maintenance Requirements}

Fuel cells require regular maintenance to minimize efficiency losses. Some necessary tasks include:

\section{Quarterly}

- replace mineral demineralizer beds

- clean water tank

- clean water filters

- replace air filters

- lubricate pump bearings

\section{Annually}

- clean deaerator column

- maintain pump

- lubricate bearings on process air blower

- clean condenser

- check spark plug

- check flame sensor

- clean ancillary cooling filters

- analyze glycol solution

- inspect accumulator

- check UPS function

- check panel boards

- test automatic power transfer switch

- check motor starters

- provide power conditioner maintenance

- calibrate I/O devices

- check power supply voltage

\section{Bi-Annually}

- maintain stack cooling pumps

- check stack cooling flow switch

- replace air conditioning filter.

After significant operating time, when fuel cell performance has dropped significantly, the stack may need to be replaced. 


\section{Case Study: Watervliet Arsenal, NY}

As part of a DOD PAFC demonstration, Watervliet Arsenal, a U.S. Army installation near Albany, NY, dedicated its 200 kW ONSI PC25B PAFC (ONSI Corp., So. Windsor, CT) on 31 October 1997, a year and a half after the initial site evaluation. The fuel cell is on the south side of the central boiler plant (Figure 13), which delivers steam 7 months of the year for space heating and manufacturing processes. The fuel cell electrical interface ties into a spare electrical panel inside the electrical room. A new breaker panel was also installed for connection to a base-specified grid-independent load. The cell's thermal output is piped through a blowdown heat exchanger and set of water softeners and is used to preheat boiler make-up water.

The system used American Society of Heating, Refrigerating, and Air-Conditioning Engineers (ASHRAE) design temperatures ranging from -1 to $88^{\circ} \mathrm{F}$. In total, the installation required approximately a $120 \mathrm{ft}$ wire run, a $110-\mathrm{ft}$ thermal piping run, a $60-\mathrm{ft}$ natural gas line, and $20 \mathrm{ft}$ of piping for the cooling module.

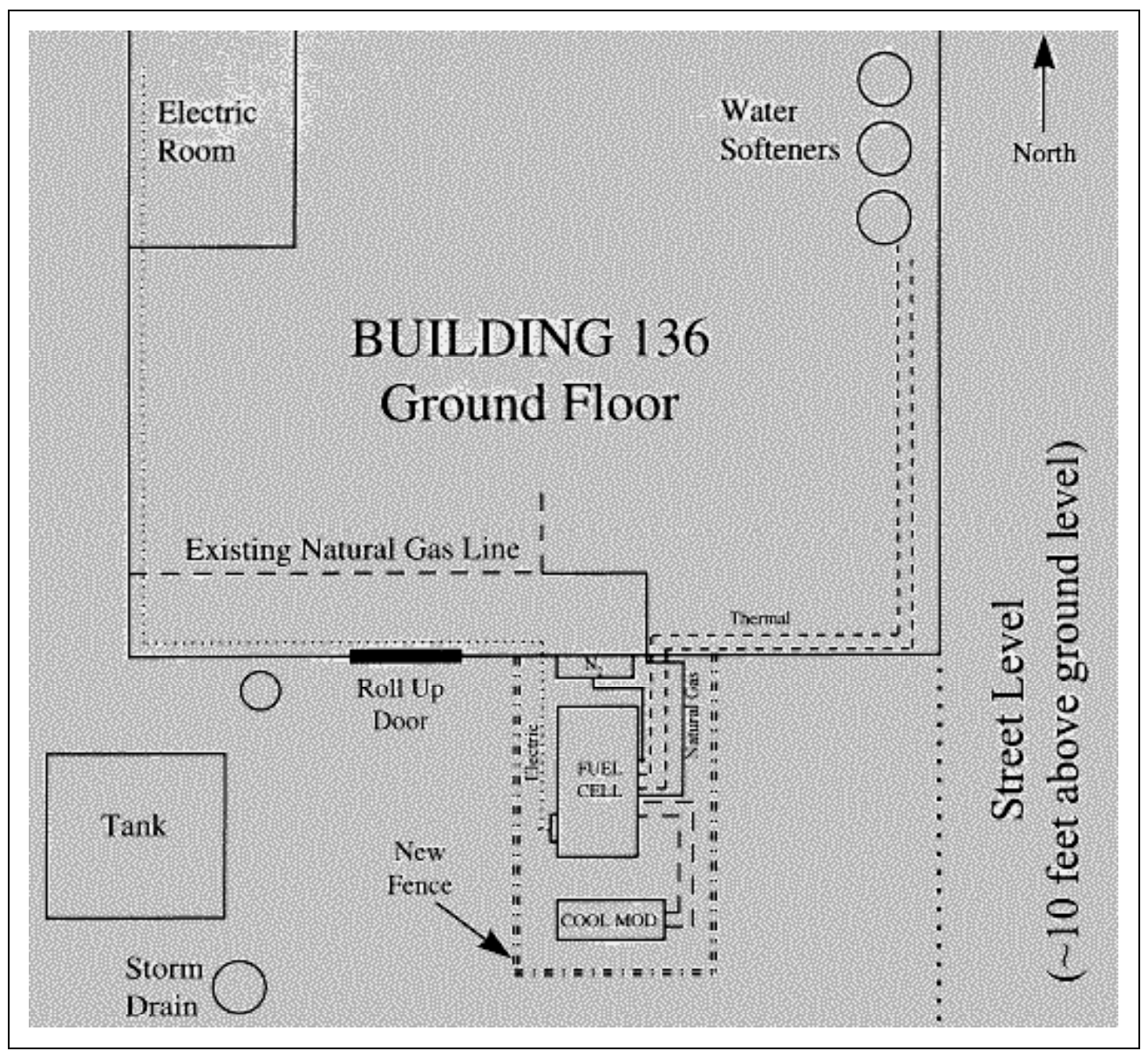

Figure 13. Watervliet Arsenal fuel cell system layout. 


\section{Actual Performance}

Table 6 lists actual performance of the Watervliet Arsenal fuel cell from 29 October 1997 to 31 January 2002.

Table 6. Actual performance of the Watervliet Arsenal fuel cell.

\begin{tabular}{|l|r|l|l|}
\hline Hours of Operation (hr) & 28,875 & Electric Efficiency (\%) & 31.4 \\
\hline Total Electric Output (MWhr) & $4,117.7$ & Thermal Efficiency (\%) & 26.0 \\
\hline Average Fuel Cell Output (kW) & 142.6 & Total Efficiency (\%) & 57.4 \\
\hline Total Heat Recovered (MMBtu) & 968.8 & Capacity Factor (\%) & 55.1 \\
\hline Heat Recovery Rate (kBtu/hr) & 33.6 & Availability (\%) & 77.3 \\
\cline { 1 - 3 } Input Fuel (cu ft) & $44,195,508$ & \multicolumn{2}{|l}{} \\
\cline { 1 - 3 } & & \multicolumn{2}{|l}{}
\end{tabular}

Watervliet Arsenal purchases electricity from Niagara Mohawk under rate schedule SC3A that has both demand charge and on-peak/off-peak energy charge components. Natural gas prices are based on a negotiated rate. Table 7 lists estimated savings on energy costs each year (for a net savings of $\$ 76,000$ ).

Table 7. Yearly savings at Watervliet Arsenal.

\begin{tabular}{|l|c|}
\hline Electric Savings & $\$ 111,000$ \\
\hline Thermal Savings & $\$ 15,000$ \\
\hline TOTAL SAVINGS & $\$ 126,000$ \\
\hline Natural Gas Cost & $(\$ 50,000)$ \\
\hline NET SAVINGS & $\$ 76,000$ \\
\hline
\end{tabular}

Since the inception of this project, the ONSI Corporation has released a PC25C PAFC and no longer supports the older PC25B models. Watervliet's maintenance contract with the DOD demonstration has expired, but energy managers on site have been so satisfied with its cost saving capabilities they have opted to keep the fuel cell in operation (Figure 14). Table 8 lists major fuel cell manufacturers.

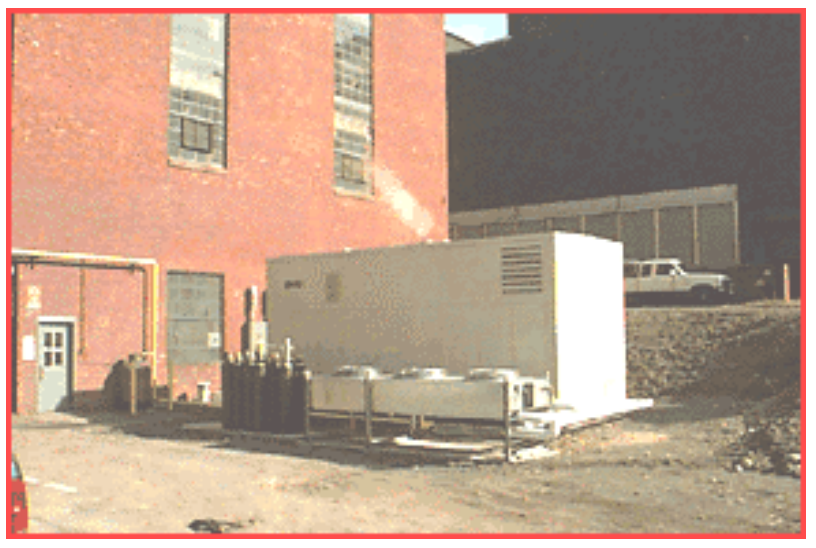

Figure 14. Watervliet Arsenal fuel cell and Building 136. 
Table 8. Major fuel cell manufacturers.

\begin{tabular}{|l|l|}
\hline Manufacturer & Web Link (URL) \\
\hline Acumentrics Corporation & http://www.acumentrics.com/ \\
\hline Allied Signal & http://www.honeywell.com \\
\hline Arotech Corp. & http://www.arotech.com \\
\hline Avista Corporation & http://www.avistacorp.com \\
\hline Astris Energi, Inc & http://www.astrisfuelcell.com/ \\
\hline Ballard Power Systems & http://www.ballard.com \\
\hline BCS Technology, Inc. & http://user.txcyber.com/ bcstech/ \\
\hline CeramTec & http://www.ceramtec.com \\
\hline Dais Analytic Corp. (DAC) & http://www.daisanalytic.com/ \\
\hline ElectroChem, Inc & http://www.fuelcell.com/ \\
\hline ECD Ovonics & http://www.ovonic.com/ \\
\hline FuelCell Energy, Inc & http://www.ercc.com/ \\
\hline Fuel Cell Technologies Ltd & http://www.fct.ca/ \\
\hline Giner, Inc & http://www.ginerinc.com/ \\
\hline Global Thermoelectric Inc & http://www.globalte.com/ \\
\hline GreenVolt Corp & http://www.greenvolt.com/ \\
\hline Hydrogenics Corp & http://www.hydrogenics.com/ \\
\hline IdaTech & http://www.idatech.com/ \\
\hline ITN Energy Systems, Inc & http://www.itnes.com/ \\
\hline McDermott Technology, Inc & http://www.mtiresearch.com/ \\
\hline Mosaic Energy & http://www.mosaicenergy.com/ \\
\hline Nuvera Fuel Cells & http://www.nuvera.com/ \\
\hline Plug Power & http://www.plugpower.com \\
\hline Siemens Westinghouse & http://www.siemenswestinghouse.com \\
\hline Sulzer Hexis Ltd & http://www.hexis.com/ \\
\hline Teledyne Technologies Inc & http://www.teledyne.com/ \\
\hline UTC Fuel Cells & http://www.utcfuelcells.com/ \\
\hline
\end{tabular}




\section{Photovoltaic Arrays}

\section{Introduction}

Edmund Bacquerel first discovered the photoelectric effect in 1839, when light was incident on an electrode in an electrolyte solution. While working with selenium, Adams and Day first observed the effect in solids in 1877. The technology developed until 1954, when researchers at Bell Labs and RCA achieved efficiencies of 6 percent with $\mathrm{p}$ and $\mathrm{n}$ semiconductors. Four years later, the United States launched the first PV-powered satellite. One of the first earthbound uses of PV was in electricity transmission. Utility companies need to keep diagnostic equipment running at various points along long-distance transmission lines. Since these lines are very high voltage, tapping into them requires stepping down the voltage to usable levels, requiring expensive equipment and often "dirtying" the electricity being transmitted by introducing unwanted harmonics in the AC. PV cells, with batteries for nighttime use, have been supplying diagnostic equipment with electricity for decades now. PV is also used to provide power for calculators, watches, water pumping, remote buildings, space vehicles, and megawatt-scale power plants. Long used only in remote applications, PV now provides as much power off-grid as grid-connected. Net metering and government subsidy programs have increased sales.

Although the price of PV modules has dropped from about $\$ 80 /$ watt in 1975 to under $\$ 4 /$ watt today, cost is still a major hindrance to the expanded use of solar power. At two to five times the cost of grid power, it cannot yet compete with traditional fossil fuels.

\section{Technology Overview}

\section{Semiconductors}

PV cells are made of semiconductors such as silicon, currently the most commonly used. Metals tend to be good conductors of electricity because they usually have "free electrons" that can move easily between atoms, and electricity involves the flow of electrons. However, a pure silicon crystal is nearly an insulator. Very little electricity will flow through it. Doping silicon ( $\mathrm{Si}$ ) can change its behavior, causing it to function as a semiconductor. In doping, a very small quantity of the impurity 
creates enough free electrons to allow an electric current to flow through the silicon. In n-type doping, phosphorus or arsenic is added to the silicon in small quantities, with extra electrons creating a negative charge. In p-type doping, boron or gallium is added, creating a positive charge with too few electrons, or "holes."

\section{PV Energy}

In a solar cell the positively and negatively charged silicon are placed together, and an electron/hole barrier is created at the junction, separating the two sides by an electric field. This electric field acts as a diode, allowing electrons to flow from the $p$ side to the $\mathrm{n}$ side (Figure 15).

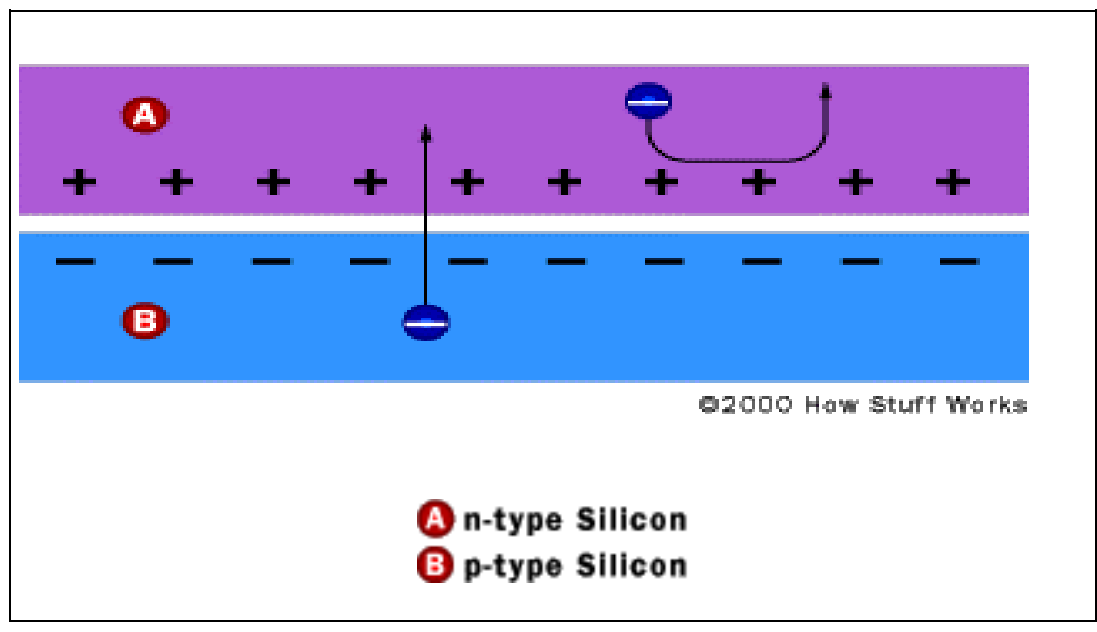

Figure 15. The effect of the electric field in a PV cell.

When light photons hit the solar cell, their energy frees electron/hole pairs. Each photon frees exactly one electron/hole pair. If this happens close enough to the electric field, the field will send the electron to the $\mathrm{n}$ side and the hole to the $\mathrm{p}$ side. This causes further disruption of electrical neutrality, and if an external current path is provided, electrons will flow through the path to their original p side (Figure 16) to unite with holes that the electric field sent there. The electron flow provides the DC, and the cell's electric field causes a voltage. Typically the electricity is converted to $\mathrm{AC}$ for end use.

\section{Efficiency}

A PV cell uses about 15 percent of sunlight's energy. Only a certain amount of "band gap energy," as defined by the cell material (about 1.1 electron-volt [eV] for crystalline silicon [c-Si]), is required to knock an electron loose. If a photon has more energy than the required amount, then the extra energy is lost. If a photon has too little energy, it simply passes through the cell. These two effects account for 
nearly 70 percent of the radiation energy lost on a cell. The band gap also determines the voltage of the electric field. The optimal band gap, balancing these two effects, is around $1.4 \mathrm{eV}$ for a cell made from a single material.

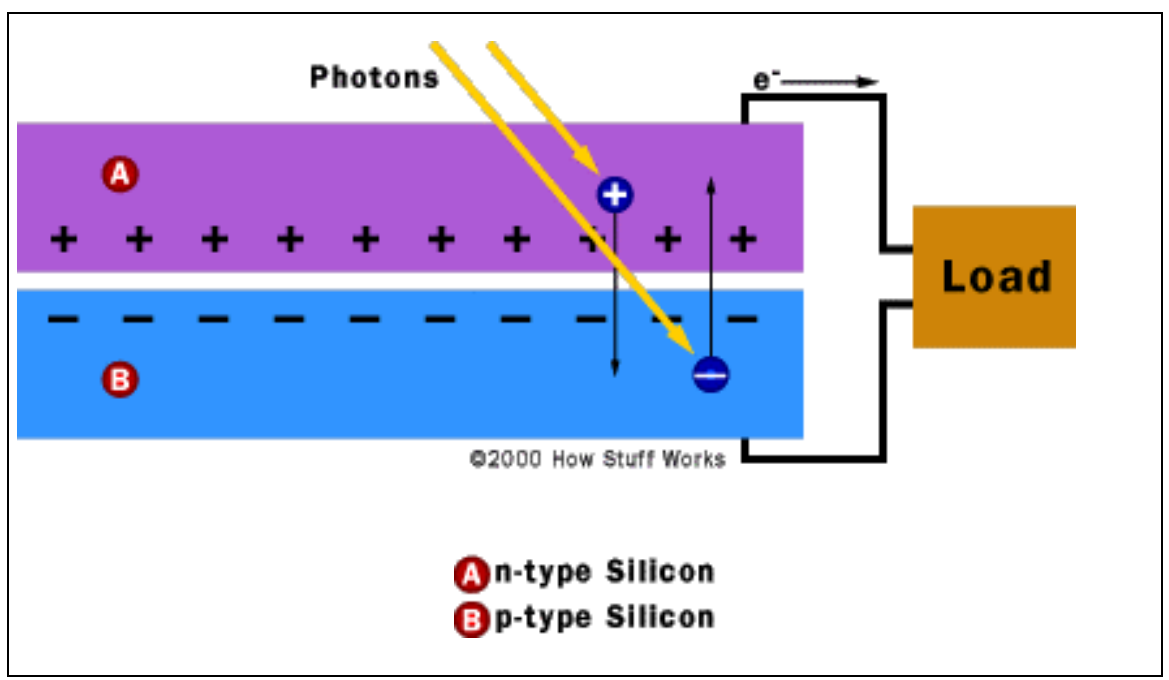

Figure 16. Operation of a PV cell.

Other losses occur in a PV cell as well. Electrons have to flow from one side of the cell to the other through an external circuit. The bottom can be covered with a metal, allowing for good conduction, but covering the top would result in a loss of current. If the contacts are placed only at the sides of the cell, then the electrons have to travel an extremely long distance to reach them. Si's series resistance is fairly high, resulting in high losses. To minimize these losses, a metallic contact grid covers the cell, shortening the distance electrons have to travel while covering only a small part of the cell surface.

\section{Photovoltaic Cell Structure}

An antireflective coating is applied to the top of the PV cell to reduce photon reflection losses to less than 5 percent. PV cells are the smallest unit of a PV system and are wired together in series and parallel to form modules of useful levels of voltage and current. The modules are sealed in units conveniently sized for handling and are wired together to form panels. They are placed in a sturdy frame with positive and negative terminals on the back, and a protective glass cover plate is added. Groups of panels form arrays, and a number of arrays make up an array field. Figure 17 shows the layers of the PV cell. 


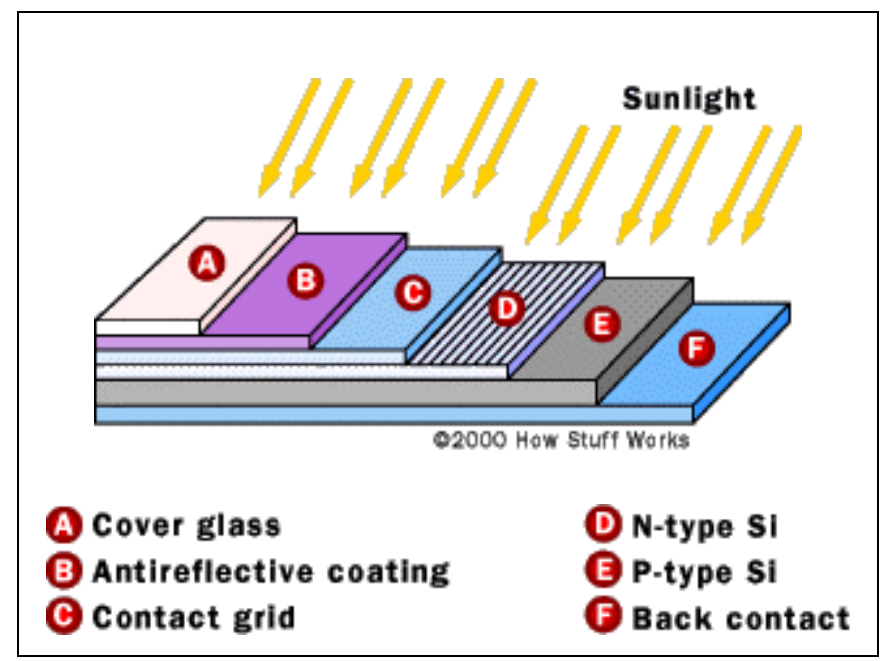

Figure 17. Basic structure of a generic silicon PV cell.

Types

\section{Crystalline silicon}

Historically, c-Si has been used as the light-absorbing semiconductor in most solar cells, accruing 88 percent of the PV market share, even though it is a relatively poor absorber of light and requires a considerable thickness (several hundred microns) of material. Nevertheless, it has proved convenient because it yields stable solar cells with good efficiencies (11 to 16 percent, half to two-thirds of the theoretical maximum) and uses process technology developed from the huge knowledge base of the microelectronics industry.

Two types of c-Si are used in the industry. The first type is monocrystalline, produced by slicing wafers (up to 150 -mm diameter and 350-microns thick) from a high-purity single crystal boule. The second type is multicrystalline silicon, made by sawing a cast block of silicon first into bars and then wafers. While multicrystalline production is less costly, it is also less efficient PV than single crystal silicon.

Each c-Si cell generates about $0.5 \mathrm{~V}$, so 36 cells are usually soldered together in series to produce a module with enough output to charge a $12 \mathrm{~V}$ battery. The cells are hermetically sealed under toughened, high transmission glass to produce highly reliable, weather resistant modules that carry warranties of up to 25 years. 


\section{Thin film}

The other 12 percent of the PV market is in thin film cells, which are typically used in low power $(<50 \mathrm{~W})$ and consumer electronics applications. The materials used are all strong light absorbers and only need to be about 1 micron thick. The most common materials are amorphous silicon or the polycrystalline materials: cadmium telluride and copper indium (gallium) diselenide. Thin film cells are laminated to produce a weather resistant and environmentally robust module. Although they are less efficient (production modules range from 5 to 8 percent), thin films are potentially cheaper than c-Si because of their lower materials costs and larger substrate size. Some thin film materials, however, have shown degradation of performance over time, and stabilized efficiencies can be 20 to 30 percent lower than initial values. Many thin film technologies have demonstrated best cell efficiencies at research scale above 13 percent, and best prototype module efficiencies above 10 percent.

\section{Electrochemical}

Electrochemical solar cells, a developing technology, have their active component in a liquid phase. A dye sensitizer is used to absorb the light and create electron-hole pairs in a semiconductor layer. This layer is sandwiched between the front tin oxide coated glass sheet and a rear carbon contact layer, with a glass or foil-backing sheet. These cells may offer lower manufacturing costs in the future because of their simplicity and use of cheap materials. Prototypes of small devices powered by dyesensitized nanocrystalline electrochemical PV cells are now appearing as $120 \mathrm{~cm}^{2}$ cells with 7 percent efficiency.

\section{PV Benefits}

PV cells offer users the following benefits:

- no fuel cost

- green power - no emissions (chemical, noise, or thermal)

- no moving parts - infrequent maintenance

- long service life - 20 to 25 years

- modular design allows scalable power

- many commercial products available

- global infrastructure support

- low weight. 


\section{PV Drawbacks}

However, PV cells do have the following drawbacks:

- high initial costs $(5000 \$ / \mathrm{kW})$

- variable power generation, depending on location, time of day, and weather

- a large footprint

- only modest efficiency.

\section{Potential Applications}

\section{Grid-Connected Systems}

In grid-connected systems, a PV system supplies electricity to the load. Any daytime excess may be exported to the grid. Batteries are not required because the grid supplies any extra demand as well as the low levels of power required at night. Solar PV modules can be retrofitted to a pitched roof above the existing roof-tiles, or the tiles can be replaced by PV roof-tiling systems. Curtain walls can be built of glass/glass PV modules, which can be semi-transparent to provide shaded light.

\section{Remote Sites}

Often solar systems can be installed to meet basic electrical needs at a lower cost than extending grid access to remote sites. PV is commonly used for lighting, communications, water pumping, offshore navigation buoys, and environmental and situation monitoring equipment systems in remote locations, using rechargeable batteries to store energy captured during daylight hours.

\section{Fuel Considerations}

Once installed, solar energy has close to zero variable costs and is not exposed to price volatility. Solar energy has technical reliability characteristics that allow it to access the premium power market. It also has good fit with most utility load curves. Its strongest fit occurs during the summer, when the daily airconditioning load in many countries fits closely with solar energy production. Figure 18 maps the concentration of solar energy in the United States. The National Renewable Energy Laboratory publishes maps on the availability of solar energy based on month and instrument orientation. This useful tool can be found at http://www.homepower.com/education/solar.cfm. 


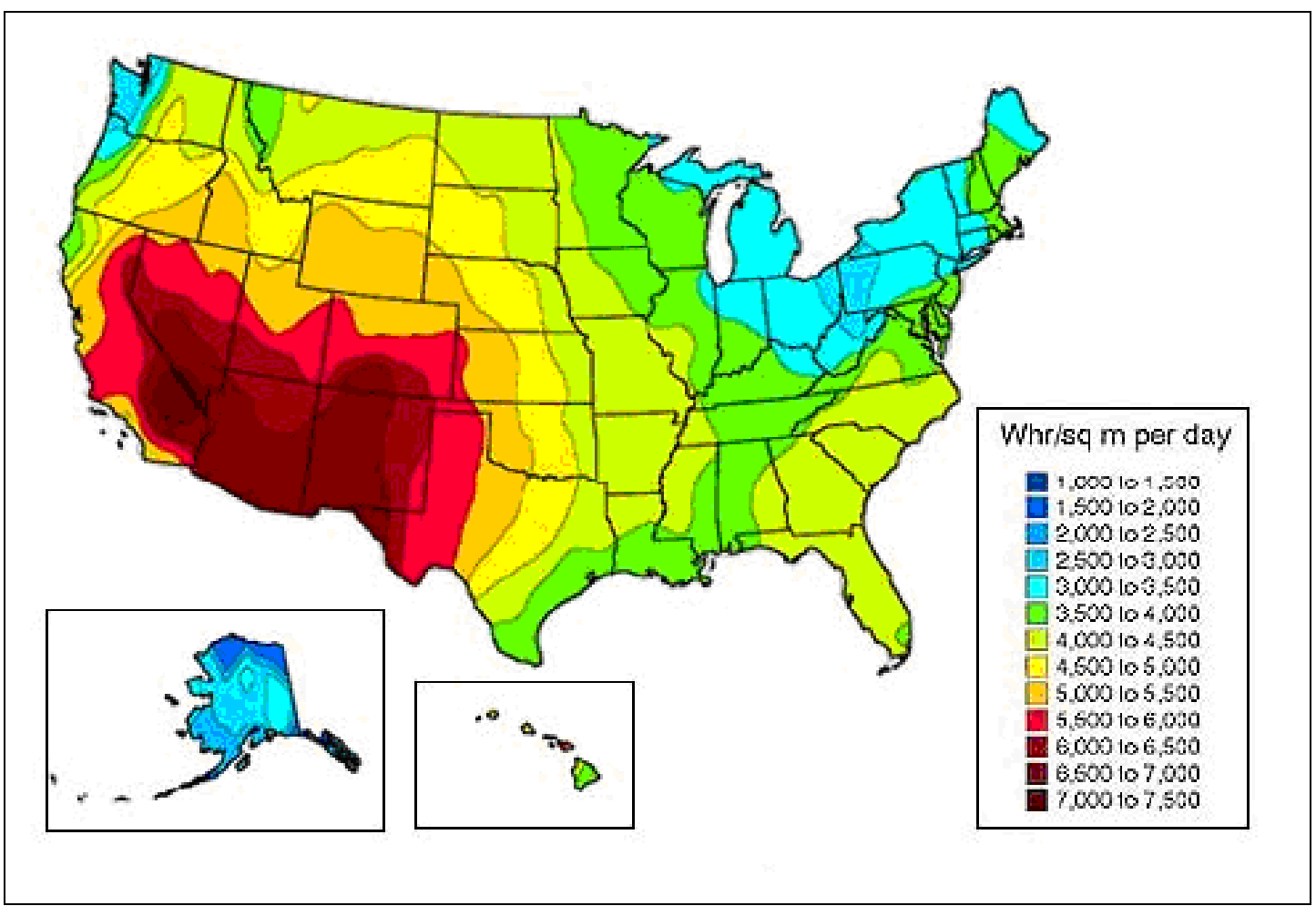

Figure 18. Availability of solar energy on a surface directly facing the sun (courtesy of Stirling Energy Systems, Inc.).

\section{Construction Considerations}

\section{Options and Configurations}

PV systems may use electromechanical sun tracking devices to maximize power output. They can operate independent of the grid, requiring a battery bank, connected to the grid, making use of PV for peak shaving or grid power during times of non-PV generation, or a hybrid of the two. The electricity produced can be used directly, stored in batteries, or fed into the utility grid. Figure 19 diagrams a typical PV system.

\section{PV System Costs}

A PV system initially costs $\$ 7,100-\$ 20,000 / \mathrm{kW}$, depending on the type of cells used. Installation adds $\$ 0$ to $\$ 2,000 / \mathrm{kW}$ and annual maintenance adds a small amount to the cost. 


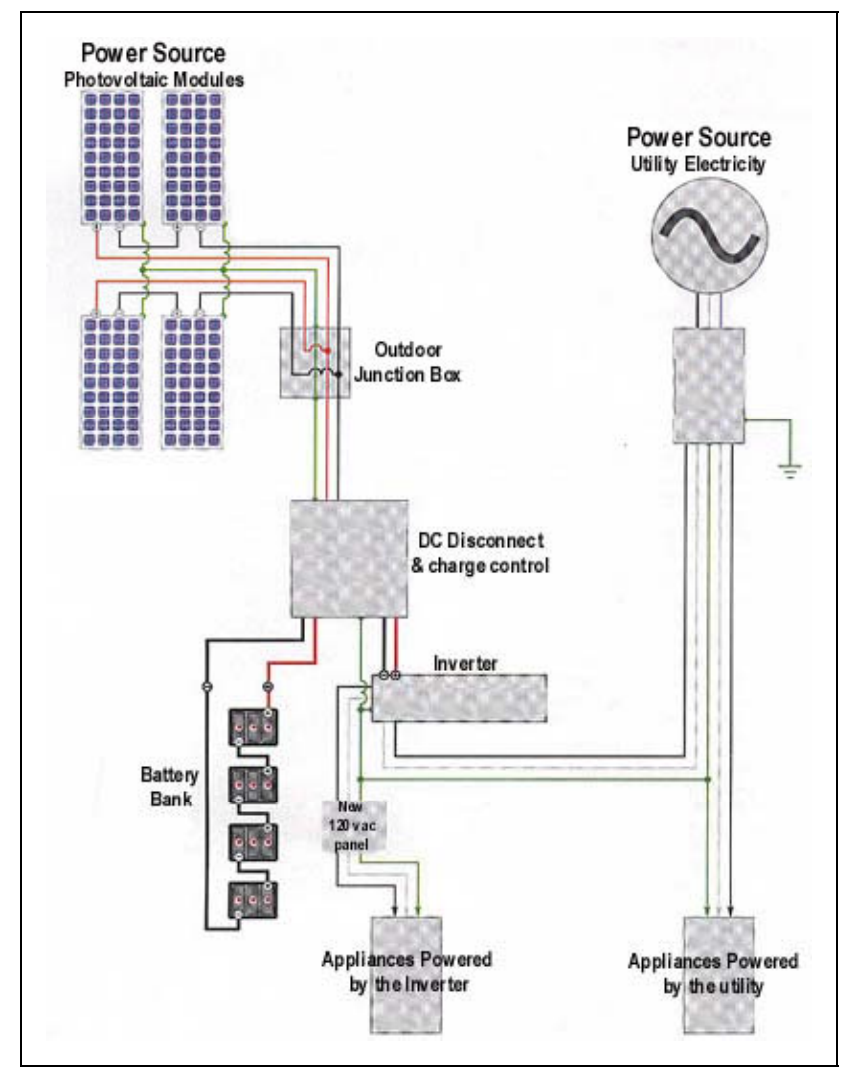

Figure 19. Typical PV system layout (courtesy of Solar Village Institute, Inc.).

\section{Applicable Codes and Standards}

The DG system must meet all applicable government standards: national, state and local construction and safety standards. The following is a partial list of relevant national standards.

\section{IEEE}

- PV Interconnection Standard 929-2000, Connection of Solar Systems to the Electricity Grid

- IEEE 519, Recommended Practice and Requirements for Harmonic Control in Electrical Power Systems

- IEEE 1374, Guide for Terrestrial Photovoltaic (PV) Power System Safety

- IEEE 1262, PV Module Qualification for Performance and Reliability

- IEEE 937, Recommended Practice for Installation and Maintenance of LeadAcid Batteries for Photovoltaic (PV) Systems

- IEEE 1145, Recommended Practice for Installation and Maintenance of Nickel-Cadmium Batteries for Photovoltaic (PV) Systems 
$U L$

- UL 1703, Flat-Plate PV Modules and Panels

- UL 1704, "Safety" Related Criteria

- UL 1741, Standard for Static Inverters and Charge Controllers for Use in Photovoltaic Power Systems

NFPA

- National Electric Code (NEC) Sec 720, also Article 690, 90-2, Electrical Installations of PV Equipment. Recommended Installation Practices (March 2001)

\section{PowerMark Corporation}

- PMC Doc. PV-3, Encompasses Jet Propulsion Laboratory (JPL) Block V, CEC 503, IEEE 1262, IEC 1215, IEC 1646, and Photovoltaics for Utility Scale Applications (PVUSA)

\section{ASTM International}

- E standards (E900-2000), Photovoltaic Cells and Module Integrity

\section{Factory Mutual}

- Fire Protection Tests for Solar Component Products

\section{Controls and Diagnostics}

All solar controllers need these features: inverter operation and overload safety cutout, battery charge control, and grid interconnection switching (for grid connected systems).

Battery charge and discharge control is required to maintain battery life. Charge levels must be controlled to avoid overcharging and excess hydrogen evolution, causing physical damage to battery plates. Charge levels below 50 to 60 percent of the nominal level should be avoided with lead acid batteries, as exceeding depth of discharge levels significantly reduces their lifetimes.

\section{Electric Distribution System Considerations}

PV cells produce DC electricity, so an inverter must usually be installed for conversion to AC electricity prior to end use. 


\section{Operation and Maintenance}

PV systems require very little maintenance and can run unattended for long periods of time. However, PV modules may have to be cleaned annually in dirty locations, especially if they are installed horizontally. Batteries will have to be replaced every 5 to 10 years.

\section{Case Study: Yuma Proving Ground, AZ}

\section{Introduction}

In spring 1997, a 450-kW PV array (pictured in Figure 20) was installed at the U.S. Army Yuma Proving Ground (YPG), to provide power for a water treatment plant. Covering 10 acres, the 8120 c-Si modules are $55 \mathrm{~W}$ Siemens M-55s. The system has an $825-\mathrm{kVA}$ peak-shaving capacity. An off-the-shelf battery bank provides 1.8-MWh of power. The array uses single axis east-west azimuth tracking and four inverters. The system is entirely automated, and operates as a hybrid in three different modes: daytime grid connected, nighttime grid connected, and off grid.

The project received the support of several U.S. Federal Agencies, including the Army, Navy, Air Force, Marines, Sandia National Laboratories, and the Western Area Power Administration. Various phases of the project were also funded and supported by the DOD's Energy Conservation Investment Program and Strategic Environmental Research and Development Program and USDOE's Photovoltaics for Utility Scale Applications.

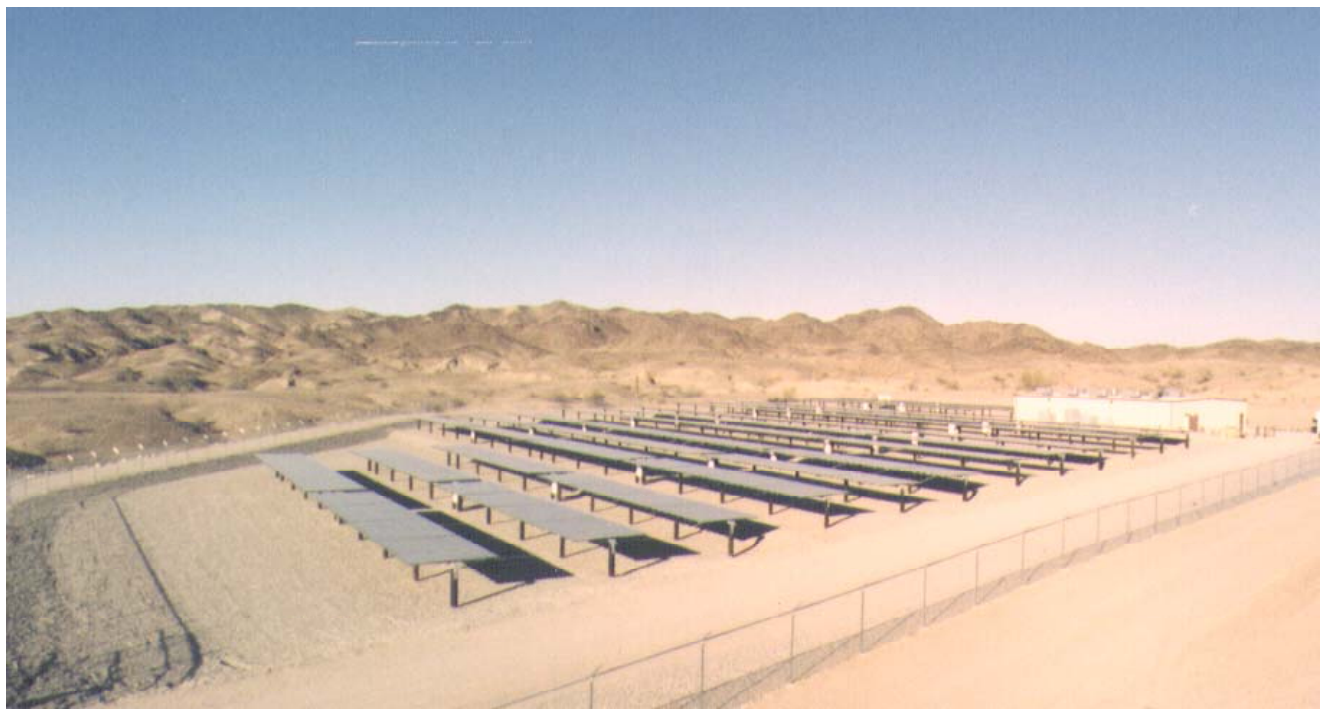

Figure 20. U.S. Army YPG PV array. 


\section{System Configuration}

The 900-kVA system Figure 21 is broken into two 450-kVA subsystems. Each 450kVA subsystem consists of two 225-kVA inverter/rectifiers; a master and a slave. Each 225-kVA inverter/rectifier includes a 225-kVA maximum power tracker (MPT) and a 225-kVA bidirectional DC/DC converter for the battery. The MPTs and the battery DC/DC converters allow the inverter/rectifiers to operate at a higher voltage than the PV array and battery. This increases both the efficiency and capacity of the inverter/rectifiers. One half of the array and battery feed the master MPTs and battery DC/DC converters, and the other half feeds the slave MPTs and battery DC/DC converters. The operating mode determines which MPTs, battery DC/DC converters, and inverter/rectifiers operate at any one point in time.

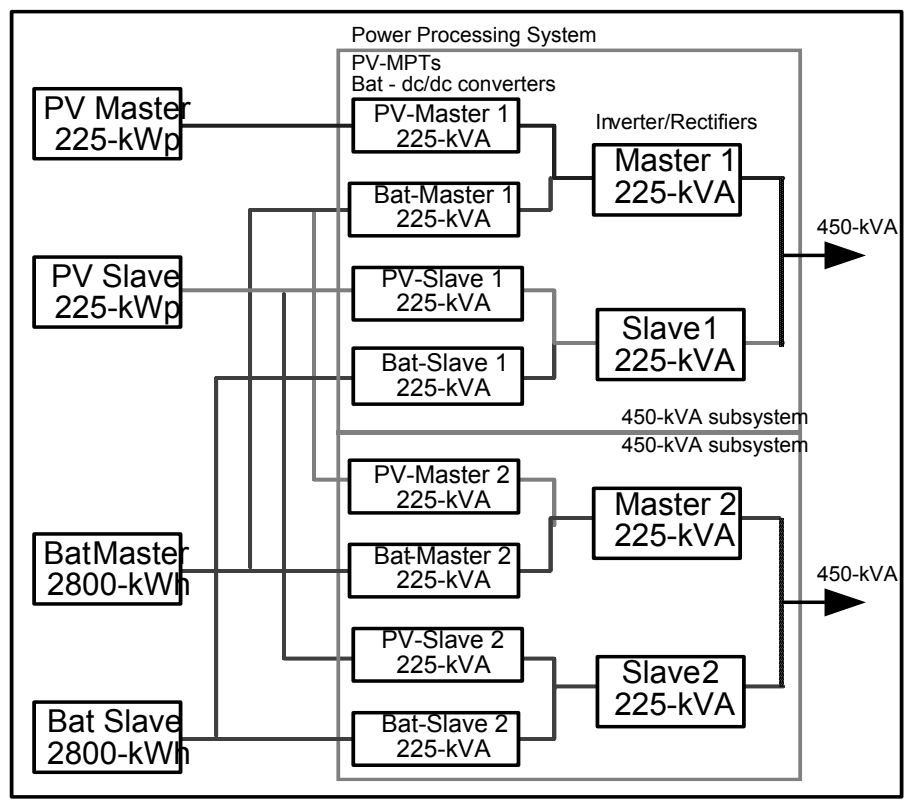

Figure 21. Block diagram of major components.

\section{Grid-Connected Mode}

Operating modes are illustrated using a typical array power profile for a summer day in Yuma (white bars in Figure 22) and an example user power profile (bold line in Figure 22). The power delivered to the grid is defined by the available PV power before hour 10 and after hour 13. In this mode, all battery DC/DC converters are inactive and only one $450 \mathrm{kVA}$ subsystem is active (Figure 23a). During hours 10 and 11 , the user power profile calls for $450 \mathrm{~kW}$. Only one $450-\mathrm{kVA}$ subsystem is active for this mode, but the battery DC/DC converters (of the active $450 \mathrm{kVA}$ subsystem) are activated to make up the difference between the available PV power and $450 \mathrm{~kW}$ (Figure 23b). All array power is delivered to the grid and only the shortfall is drawn from the battery. This direct use of the array power realizes the maximum 
possible benefit from the array. Between hours 12 and 13 , when $750 \mathrm{~kW}$ are required, both $450 \mathrm{kVA}$ subsystems are active. One subsystem processes the array power (the battery DC/DC converters are disabled), and the other processes the battery power. In this mode, one 450-kVA subsystem can deliver up to approximately $375 \mathrm{kVA}$ from the array and the other 450-kVA subsystem can deliver up to $450 \mathrm{kVA}$ from the battery for a total of $825 \mathrm{kVA}$ delivered to the grid. Only operating both subsystems when needed increases the overall system life. Both $450 \mathrm{kVA}$ subsystems and all battery DC/DC converters can be activated to fully charge the battery (Figure 23d) from the grid each night.

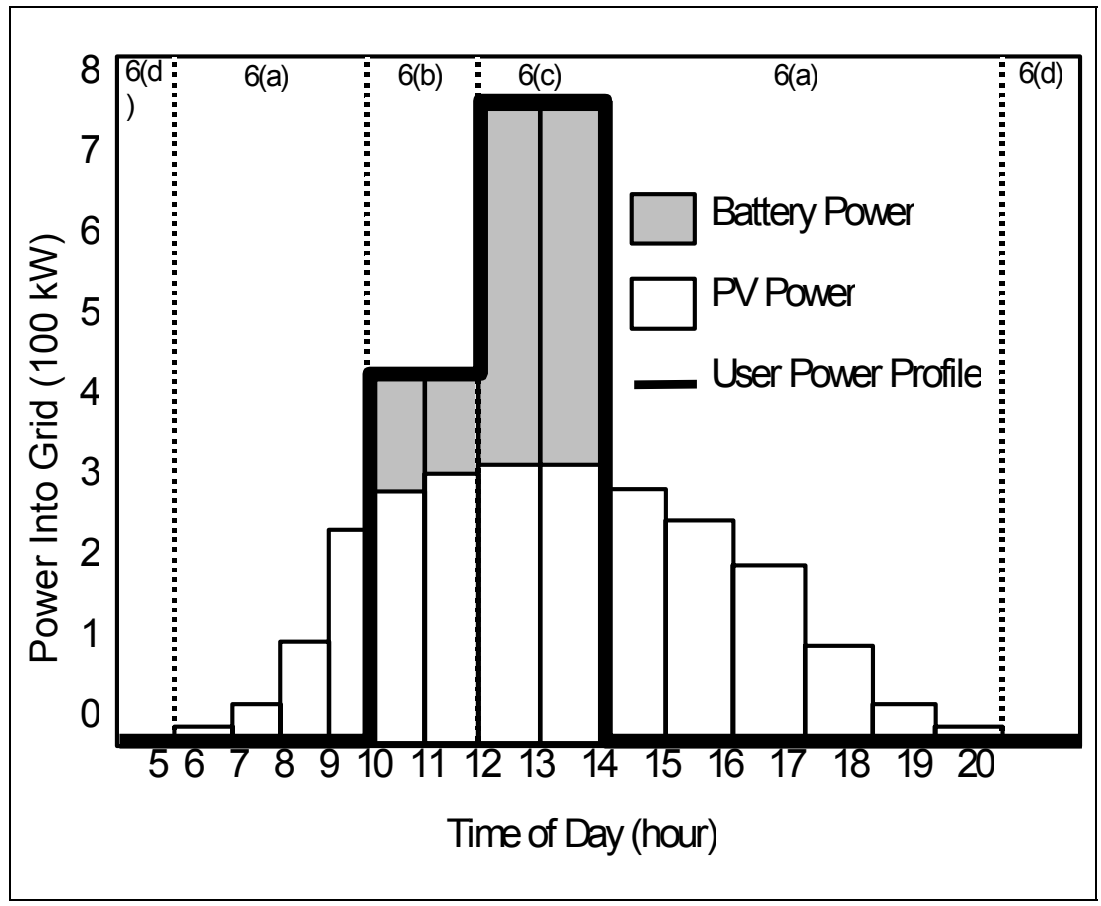

Figure 22. Power delivered for various operating modes.

\section{Off-Grid Mode}

The power processing system will automatically switch from the utility-tied mode to the standalone mode in the event of a utility outage, and it will automatically switch back to the utility-tied mode when utility service is restored. Only one of the 450-kVA subsystems can operate in the standalone mode at a time (Figure 23b). If the available PV power exceeds the power demand of the water treatment plant, the excess PV power is used to charge the battery through the battery DC/DC converters. 


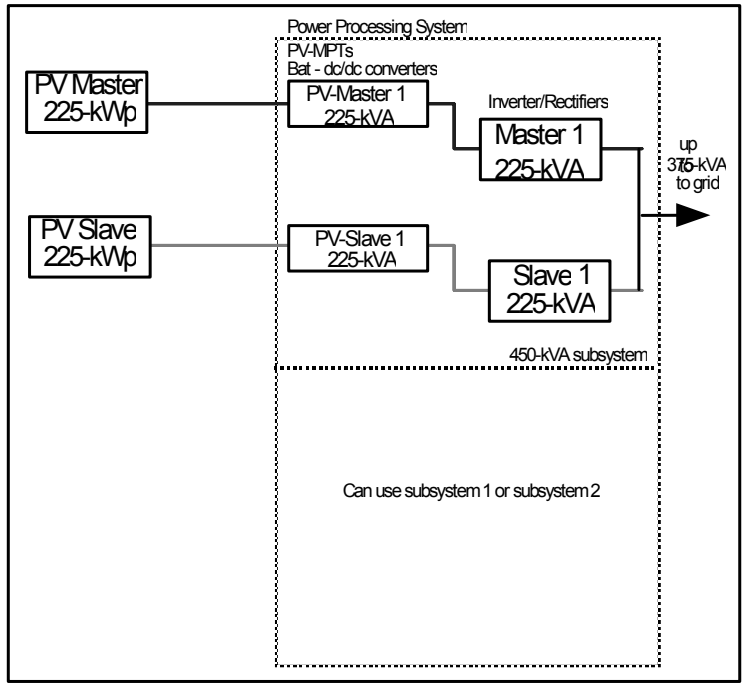

((a) Daytime utility-tied mode, with PV power greater than user profile.

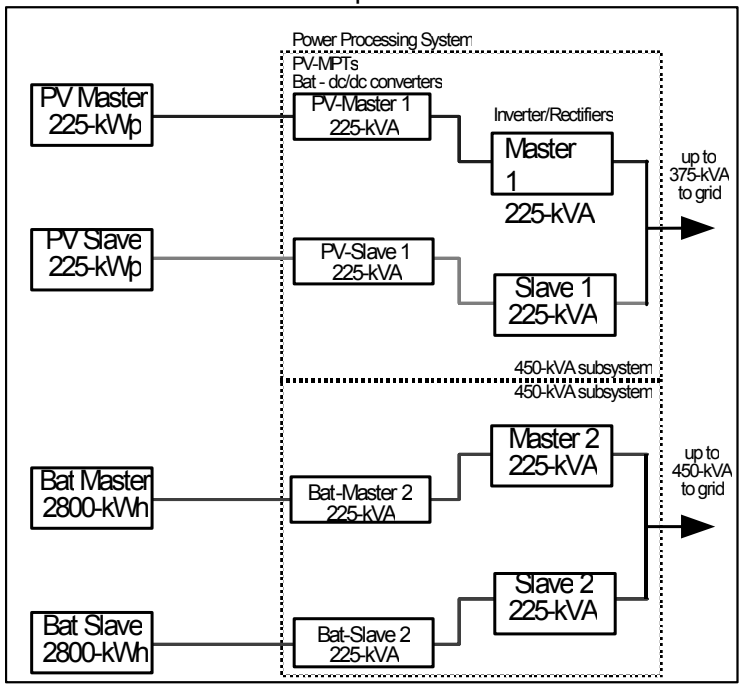

(c) Daytime utility-tied mode, with user profile (greaterthan 450-kVA) greater than PV power.

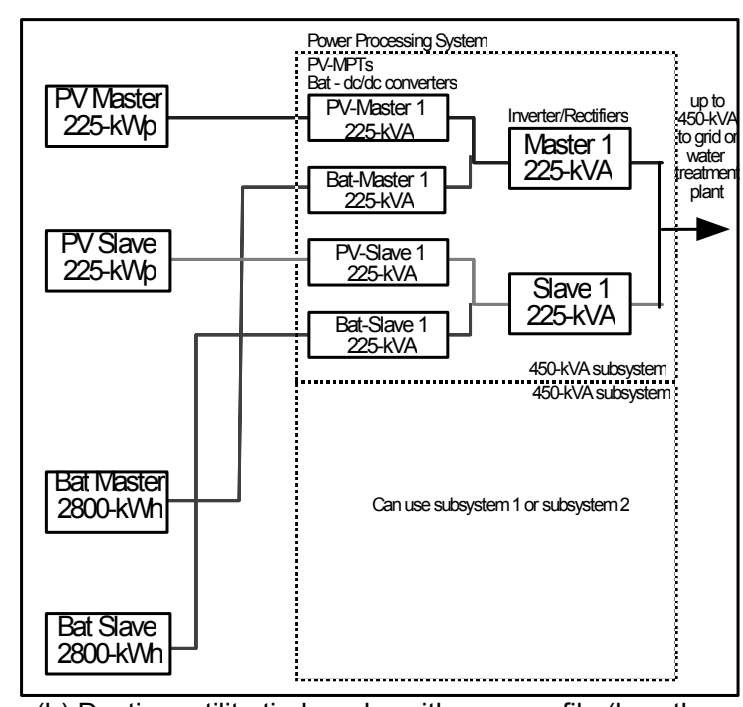

(b) Daytime utility-tied mode, with user profile (less than 450-kVA) greater than PV power, and stand-alone mode.

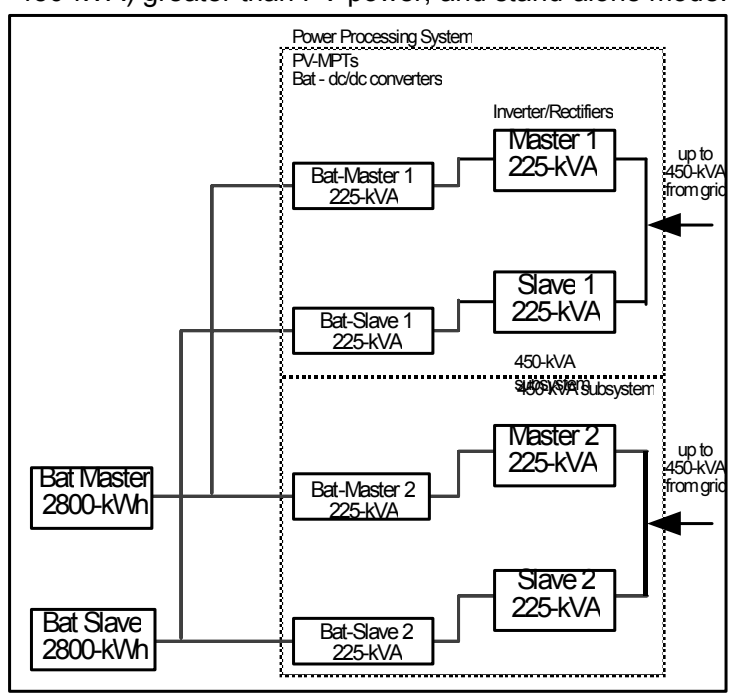

(d) Nighttime utility-tied mode for battery charging.

Figure 23. Operating modes for the YPG PV power station (courtesy of Roch Ducey, ERDC/CERL).

\section{System Controller}

The controller is based on a system of microprocessors. Distributed processors monitor and interface with the subsystems, while a personal computer (PC) collects and analyzes the system status data and then determines the appropriate operating mode for each subsystem. A remote isolation switch implements the isolation of the water treatment plant.

\section{Performance}

Operators of the YPG PV plant report no major maintenance problems. At one point, a severe windstorm bent some of the tracking mechanisms, made of 0.75-in. 
steel, preventing the panels from tracking correctly. This problem was corrected by simply bending the tracks back into place. The system is operating at a 7.5-year payback period, as initially estimated. Operators have found scattered light can produce up to 60 percent output on cloudy days. This project has significantly advanced systems integration and power conditioning technologies, to a point that more large-scale, isolated-grid PV/diesel hybrid power plant applications can be identified and implemented within DOD. There are many off-grid DOD facilities that could take advantage of the benefits that these systems have to offer. Table 9 lists some major PV manufacturers and contact information.

Table 9. Major PV manufacturers.

\begin{tabular}{|l|l|}
\hline Manufacturer & Web Link (URL) \\
\hline RWE Schott Solar, Inc. & http://www.asepv.com \\
\hline AstroPOwer & http://www.astropower.com \\
\hline BP Solar & http://www.bpsolar.com \\
\hline Canrom Photovoltaics, Inc & http://www.canrom.com \\
\hline Ebara Solar, Inc. & http://www.ebarasolar.com \\
\hline ECD Ovonics & http://www.ovonic.com \\
\hline Energy Photovoltaics, Inc & http://www.epv.net \\
\hline Evergreen Solar, Inc & http://www.evergreensolar.com \\
\hline First Solar LLC & http://www.firstsolar.com \\
\hline Global Solar Energy & http://www.globalsolar.com \\
\hline Mitsubishi Heavy Industries, Ltd & http://www.mhi.co.jp/power/e_power/techno/index01.htm \\
\hline Shell Solar & http://www.shell.com/home/Framework?siteld=shellsolar \\
\hline Solec International, Inc & http://www.solecsolar.com \\
\hline TerraSolar & http://www.terrasolar.com \\
\hline United Solar Systems & http://www.uni-solar.com \\
\hline Viva Solar Inc & http://www.vivasolar.com \\
\hline
\end{tabular}




\section{Summary}

Distributed generation, whether used for standby generation, peak shaving, remote/standalone, combined heat and power (cogeneration), or premium power, whether less than a kilowatt to tens of megawatts in size, is a potential solution to the energy dilemma facing the United States. It can benefit the economy and environment, increase domestic employment, and increase product exportation. DG can provide electricity to remote sites and reliable backup power for critical, gridconnected facilities. It can lower stress on the grid by supplying extra power during peak periods. It can increase efficiency through cogeneration and increase national energy independence, security, and diversity. DG reduces the necessity to build new transmission/distribution lines or upgrade existing ones. It creates new employment opportunities here in the United States rather than overseas oil fields.

This report introduces several DG technologies, including fuel cells, microturbines, wind turbines, PV arrays, and Stirling engines. It addresses issues such as fuel availability, construction considerations, and protection controls, and provides direction to further information. The included case studies demonstrated DG in use.

Implemented simply to meet the government's electricity demands, higher efficiency DG could create extraordinary energy cost savings, but Federal leadership is needed to demonstrate to the general public the feasibility of DG and to expand its use. Federal rebate or incentive programs could subsidize DG technology to the point where it is competitive with other generating technologies. Anyone responsible for providing energy for any process is encouraged to investigate the latest DG-related technological developments, codes, and standards, and take part in increasing national energy independence and security. 


\section{References}

\section{Web Sites}

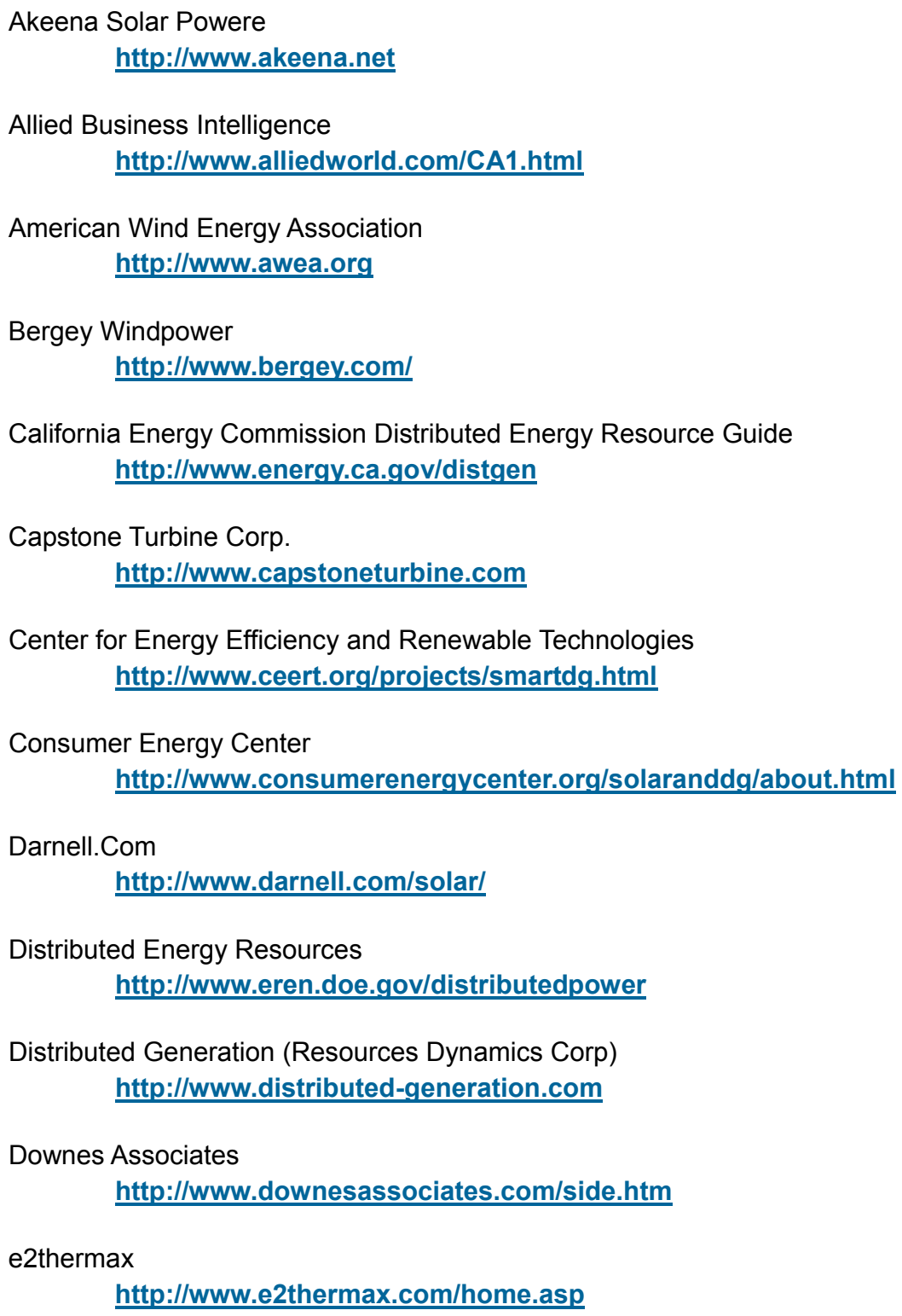


Encorp

http://www.distributedgeneration.com

Energy Conservation and Renewables

http://www.ecoiq.com/energy/index.html

Energy Info Source

http://energyinfosource.com/dg

Engineering News-Record

http://enr.construction.com/new/coverstry 40901.asp

ERDC/CERL DOD Fuel Cell Programs

http://www.dodfuelcell.com

Glenn Research Center

http://www.grc.nasa.gov

Home Power Journal

http://www.homepower.com/education/solar.cfm

HowStuffWorks

http://www.howstuffworks.com

Institute for Local Self-Reliance

http://www.ilsr.org

Marson Energy (Brackney, PA)

http://www.marsonenergy.com

National Rural Electric Cooperative Association (Distributed Generation Interconnection Tool Kit) http://www.nreca.org/leg reg/DGToolKit

New York State Energy Research and Development Association

http://www.nyserda.org

New York State Public Service Commission

http://www.dps.state.ny.us/distgen.htm

Northern Power Systems http://www.northernpower.com

Ocean Power Corp.

http://www.powerco.com

Pacific Power Solutions, Inc. http://www.pacificpowersolutions.com

Piedmont Energy \& Communications Group, Inc. http://www.pecgrp.com

Power Generation Magazine http://pe.pennnet.com/home.cfm

REFOCUS Magazine

http://www.re-focus.net 
Renew Wisconsin (Distributed Resources in Wisconsin Collaborative Group) http://www.renewwisconsin.org/dg/dg1.html

Sandia National Laboratories http://www.sandia.gov

Shinozuka, Jun, Ph.D. (Stirling Engine and Steam Engine) http://jenny.mes.titech.ac.jp/jshinozu/Engine/engine.html

Solar Village Independent Renewable Power http://www.solarvillageinstitute.com

SolarBuzz

http://www.solarbuzz.com

Sterling Planet http://www.sterlingplanet.com/sp/electronFlow.jsp

Stirling Energy Systems, Inc. http://www.stirlingenergy.com/default.asp

Stirling Technology Corp. http://stirlingtech.com/about/index.shtml

Stirling Technology, Inc. http://www.stirling-tech.com

Sure Power Corp. http://hi-availability.com/welcome.html

The American Solar Energy Society http://www.ases.org

The Stirling Engine Society - USA http://www.sesusa.org

U.S. Fuel Cell Council http://www.usfcc.com

Underwriters Laboratories, Inc. (Distributed Generation Equipment and Energy Sources) http://www.ul.com/dge/index.html

WindPower

http://www.windpower.org/core.htm 


\section{Publications}

Binder, Michael, Franklin H. Holcomb, and William R. Taylor. 2001. Site Evaluation for Application of Fuel Cell Technology - Watervliet Arsenal, NY, U.S. Army Engineer Research and Develoment Center, Construction Engineering Research Laboratory (ERDC/CERL) Technical Report (TR)-01-18, ADA388687.

Borbely, Ann-Marie and Jan F. Kreider. 2001. Distributed Generation: The Power Paradigm for the New Millennium. Boca Raton: CRC Press.

Ducey, Roch, Sam Edwards, and Richard Chapman. 1997. "The U.S. Army Yuma Proving Ground 900-kVA Photovoltaic Power Station Report," 26th IEEE Photovoltaic Specialists Conference, September 29 - October 3, 1997, Anaheim, CA.

Holcomb, Franklin H., Michael J. Binder, William R. Taylor, Michael J. Torrey, and John F. Westerman. 2000. Phosphoric Acid Fuel Cells. ERDC/CERL TR-00-33, ADA386669.

Institute of Electrical and Electronics Engineers (IEEE) 519-1992. "Recommended Practices and Requirements for Harmonic Control in Electrical Power Systems,” IEEE, New York, NY.

New York State Public Service Commission. 1999. New York State Standardized Interconnection Requirements, Application Process, Contract \& Application Forms for New Distributed Generators, 300 Kilovolt Amperes or less, Connected in Parallel with Radial Distribution Lines. December 1999.

Parker, Graham. Fort Drum Microturbine Demonstration Project presentation at the Corps of Engineers National Energy Team (CENET) Meeting, Nashville, TN, April 30, 2002, Pacific Northwest National Laboratories.

Resource Dynamics Corporation. Distributed Generation Sourcebook. Vienna: RDC, 2002.

Taylor, William R. "Microturbines," North Carolina Agricultural and Technical (NCA\&T) State University, Distribution Generation (DG) Workshop, Greensboro, NC, 11 April 2002.

U.S. Department of Energy, Wind Energy Resource Atlas http://rredc.nrel.gov/wind/pubs/atlas/atlas_index.html 


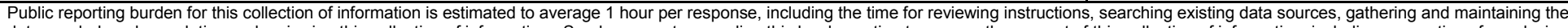

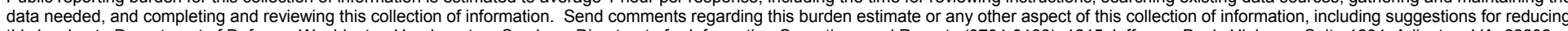

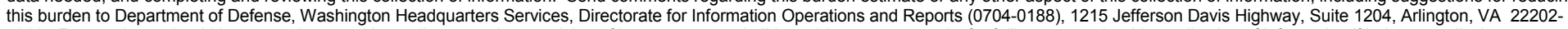

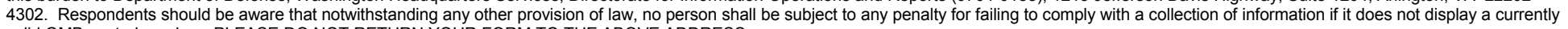
valid OMB control number. PLEASE DO NOT RETURN YOUR FORM TO THE ABOVE ADDRESS.
1. REPORT DATE (DD-MM-YYYY)
2. REPORT TYPE
09-2003
Final

4. TITLE AND SUBTITLE

3. DATES COVERED (From - To)

Distributed Electrical Power Generation:

Summary of Alternative Available Technologies

5a. CONTRACT NUMBER

W81EWF-2094-5873

5b. GRANT NUMBER

5c. PROGRAM ELEMENT NUMBER

6. AUTHOR(S)

Sarah J. Scott, Franklin H. Holcomb, and Nicolas M. Josefik

5d. PROJECT NUMBER

MIPR

5e. TASK NUMBER

5f. WORK UNIT NUMBER

7. PERFORMING ORGANIZATION NAME(S) AND ADDRESS(ES)

U.S. Army Engineer Research and Development Center (ERDC)

Construction Engineering Research Laboratory (CERL)

8. PERFORMING ORGANIZATION REPORT

NUMBER

ERDC/CERL SR-03-18

PO Box 9005

Champaign, IL 61826-9005

9. SPONSORING / MONITORING AGENCY NAME(S) AND ADDRESS(ES)

10. SPONSOR/MONITOR'S ACRONYM(S)

Office of the Director, Defense, Research \& Engineering (ODDR\&E)

1770 Kent St., Suite 9030

Rosslyn, VA 22209

11. SPONSOR/MONITOR'S REPORT NUMBER(S)

\section{DISTRIBUTION / AVAILABILITY STATEMENT}

Approved for public release; distribution is unlimited.

\section{SUPPLEMENTARY NOTES}

Copies are available from the National Technical Information Service, 5285 Port Royal Road, Springfield, VA 22161.

\section{ABSTRACT}

The Federal government is the greatest consumer of electricity in the nation. Federal procurement and installation of higher efficiency energy sources promises many benefits, in terms of economy, employment, export, and environment. While distributed generation (DG) technologies offer many of the benefits of alternative, efficient energy sources, few DG systems can currently be commercially purchased "off the shelf," and complicated codes and standards deter potential users. Federal use of DG demonstrates the technology, can help drive down costs, and can help lead the general public to accept a changing energy scheme. This work reviews and describes various distributed generation technologies, including fuel cells, microturbines, wind turbines, photovoltaic arrays, and Stirling engines. Issues such as fuel availability, construction considerations, and protection controls are addressed. Sources of further information are provided.

\section{SUBJECT TERMS}

alternative energy

distributed generation (DG)

\begin{tabular}{|c|c|c|}
\hline $\begin{array}{l}\text { a. REPORT } \\
\text { Unclassified }\end{array}$ & $\begin{array}{l}\text { b. ABSTRACT } \\
\text { Unclassified }\end{array}$ & $\begin{array}{l}\text { c. THIS PAGE } \\
\text { Unclassified }\end{array}$ \\
\hline
\end{tabular}

energy conservation

\begin{tabular}{|c|c|c|}
\hline $\begin{array}{c}\text { 17. LIMITATION } \\
\text { OF ABSTRACT }\end{array}$ & $\begin{array}{c}\text { 18. NUMBER } \\
\text { OF PAGES }\end{array}$ & $\begin{array}{c}\text { 19a. NAME OF RESPONSIBLE PERSON } \\
\text { Franklin H. Holcomb }\end{array}$ \\
\cline { 3 - 3 } SAR & 82 & $\begin{array}{c}\text { 19b. TELEPHONE NUMBER (in- } \\
\text { clude area code) } \\
\text { (217) } 352-6511, X-7412\end{array}$ \\
\hline
\end{tabular}

Standard Form 298 (Rev. 8-98) Prescribed by ANSI Std. 239.18 